University of Louisville

ThinkIR: The University of Louisville's Institutional Repository

Electronic Theses and Dissertations

$12-2006$

\title{
Amphibian colonization of new habitat : "if you build it, they will come".
}

Piper Lee Roby-Thomas 1977-

University of Louisville

Follow this and additional works at: https://ir.library.louisville.edu/etd

\section{Recommended Citation}

Roby-Thomas, Piper Lee 1977-, "Amphibian colonization of new habitat : "if you build it, they will come"." (2006). Electronic Theses and Dissertations. Paper 1223.

https://doi.org/10.18297/etd/1223

This Master's Thesis is brought to you for free and open access by ThinkIR: The University of Louisville's Institutional Repository. It has been accepted for inclusion in Electronic Theses and Dissertations by an authorized administrator of ThinkIR: The University of Louisville's Institutional Repository. This title appears here courtesy of the author, who has retained all other copyrights. For more information, please contact thinkir@louisville.edu. 


\title{
AMPHIBIAN COLONIZATION OF NEW HABITAT: IF YOU BUILD IT, THEY WILL COME
}

\section{By}

Piper L. Roby-Thomas

B.A., Hanover College, 1999

\author{
A Thesis \\ Submitted to the Faculty of the \\ Graduate School of the University of Louisville \\ in Partial Fulfillment of the Requirements \\ for the Degree of
}

Master of Science

Department of Biology

University of Louisville

Louisville, Kentucky

December 2006 


\title{
AMPHIBIAN COLONIZATION OF NEW HABITAT: \\ IF YOU BUILD IT, THEY WILL COME
}

\author{
By \\ Piper L. Roby-Thomas \\ B.A., Hanover College, 1999
}

A Thesis Approved on

December 5, 2006

By the following Thesis Committee:

Thesis Director 


\section{DEDICATION}

This thesis is dedicated to my husband

\section{Rob Thomas}

who has always supported my decisions and has given me endless encouragement to do my best.

I also dedicate this thesis to my parents

Mr. Robert Roby

and

Mrs. Lela Roby

who ignited and fed my interest in the biological sciences, and who are always there for me. 


\section{ACKNOWLEDGEMENTS}

I would like to thank my major advisor, Dr. Perri Eason for her guidance through my graduate school experience. I would also like to thank my committee member Dr. Jeff Jack for helping with travel to and from the research site and also for lending me his lab equipment and students. Thank you to my undergraduate advisor at Hanover College, Dr. Daryl Karns for being on my committee. Catie Byers was of invaluable assistance in the field and an extraordinary colleague and friend. Many thanks to Wes Daniel, Christopher Owen, Richard Pirkle, and David Word for help with many aspects of my project and moral support. Robert Johnson was critical in helping with statistical analysis. Stacy Pritchard and Richard Schultz conducted the water chemistry analysis. Several staff members at Bernheim Arboretum and Research Forest were integral in making this project happen: Dena Garvue showed so much kindness and patience with my many questions, Kani Meyer was extremely generous sharing mapping files, and Margaret Shea helped me get this project started. Joe Cichan with Frogloggers at Bernheim Forest graciously exchanged e-mails with me concerning the status of anurans at Bernheim Forest. John MacGregor at Kentucky Fish and Wildlife Service was kind enough to meet with me and exchange e-mails regarding identification of larval frogs and salamanders. Mark Gumbert at Copperhead Environmental Consulting, Inc. also assisted in identification and offered much moral support. This project was funded in part by the Biology Graduate Student Association (BGSA) at the University of Louisville (UofL) and the Center for Environmental Science as part of the Kentucky Institute for the 
Environment and Sustainable Development (KIESD), also at UofL. The University of Louisville Stream Institute and the United States Environmental Protection Agency (USEPA) supported the stream restoration. Grant money received from the Kentucky Society of Natural History (KSNH) was also used in this study. 


\section{ABSTRACT \\ AMPHIBIAN COLONIZATION OF NEW HABITAT: IF YOU BUILD IT, THEY WILL COME}

Piper L. Roby-Thomas

December 5, 2006

In 2003, Wilson Creek running through Bernheim Arboretum and Research Forest in central Kentucky was restored to its original winding path through a valley field. Early $20^{\text {th }}$ century settlers had previously redirected this creek to run a straight path along the eastern hillside in order to maximize the valley for farming. As part of the restoration to its pre-settler path, seven ponds were created in the corridor of the old streambed, which created habitat for pond-breeding amphibians. Sampling began one year after construction was complete, and over two years the amphibian assemblages of these ponds were compared to those of five ponds $>30$ years old. All six backwater ponds and three upland forest ponds per year were visually assessed and dip-netted for any amphibian life stage: egg, larvae or adult. In addition, 15 mostly ephemeral pools also created from the restoration were monitored for species richness only. The physical characteristics of all permanent ponds were also described by their perimeter size, maximum water depth, elevation, and distance to a forest edge. They were also sampled twice a year for various water chemistry parameters: nitrate-nitrite, ammonia, total 
nitrogen, soluble reactive phosphorus, total phosphorous, $\mathrm{pH}$, silica, chlorine, dissolved organic carbon, total suspended solids, turbidity, and conductivity. Fourteen amphibian species were recorded in all, but only eleven species were found in the backwater ponds. Two species documented from all of the mature ponds and in only one of the backwater ponds were Rana sylvatica and Ambystoma jeffersonianum. Other species that were documented in the older ponds but were in low numbers in the new ones were Ambystoma maculatum and Notophthalmus viridescens. The hypothesis that older upland forest ponds would have higher species richness and higher capture rate (i.e., abundance) than the backwater ponds was supported. The hypothesis that the backwater ponds would increase in species richness from 2005 to 2006 was supported, but capture rate did not increase significantly. The ephemeral pools housed mainly $H$. chrysoscelis and $B$. americanus and may be significant breeding habitat for $H$. chrysoscelis. With regards to the physical parameters, the backwater ponds were significantly closer to a forest edge and lower in elevation. They did not have significantly different perimeter sizes or water depth, but they were slightly larger and shallower. The backwater ponds may be experiencing a slight edge effect, thereby being less attractive to some amphibian species. The water chemistry variables $\mathrm{pH}$ and conductivity were significantly higher in the backwater ponds compared to the upland forest ponds. These factors may be partially correlated with the lack of certain species, but the values for the physical and chemical parameters are within range to support healthy amphibian populations. When considering future restoration projects, a combination of permanent, semi-permanent and ephemeral pools should be considered to support the greatest diversity (i.e., highest species richness and abundance) of amphibian species. Time is needed for the new ponds 
to come to ecological equilibrium and be colonized by sustainable breeding populations of amphibian species. New species arrived even three years after construction of the ponds was complete and they still did not contain the level of species richness of the older, established ponds. More than four years of monitoring are needed to determine success of a restoration project that includes creating pond-breeding amphibian habitat. 


\section{TABLE OF CONTENTS}

\section{PAGE}

ACKNOWLEDGEMENTS .......................................................

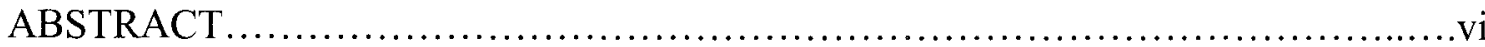

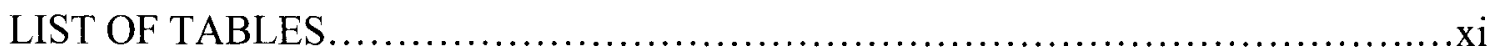

LIST OF FIGURES ....................................................................

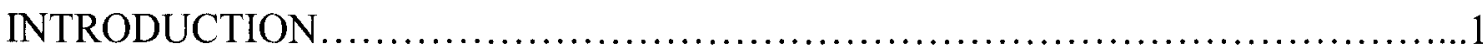

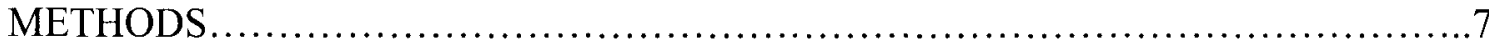

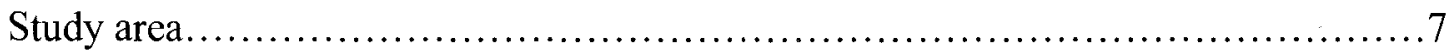

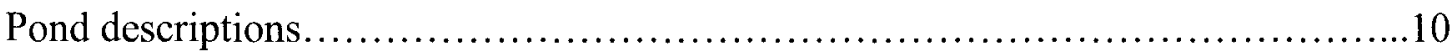

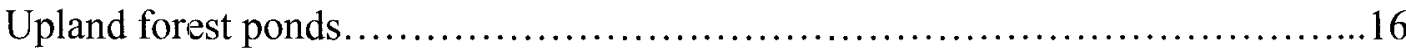

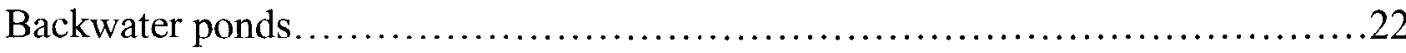

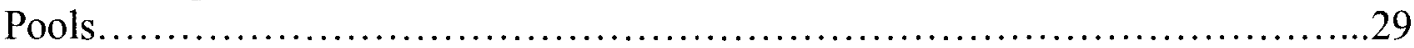

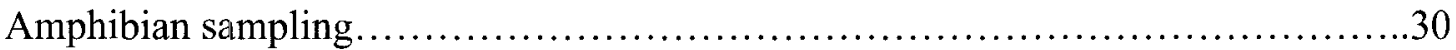

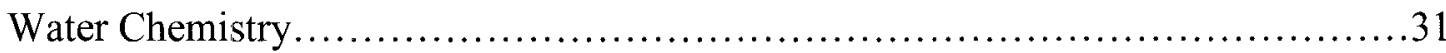

Statistical Analysis........................................................ 32

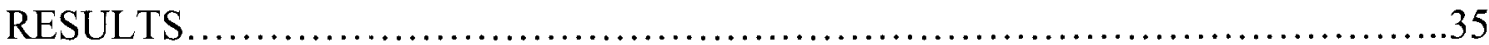

Physical parameters and water chemistry ...................................... 35

Amphibian compostion ....................................................41

How physical and chemical factors affect amphibian assemblage ..................50

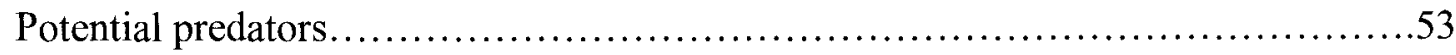

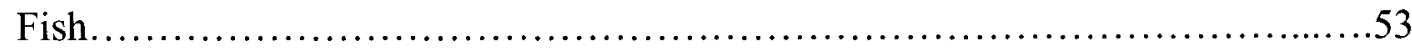

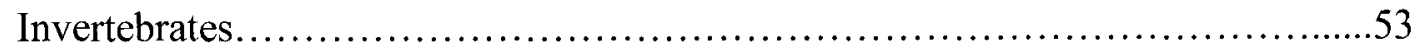

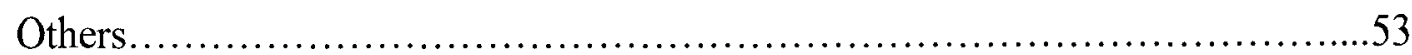




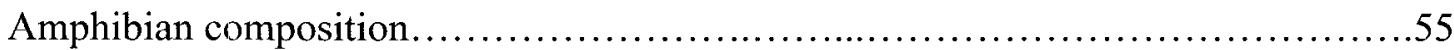

Physical characteristics.....................................................56

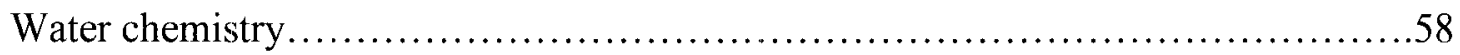

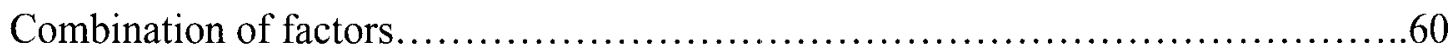

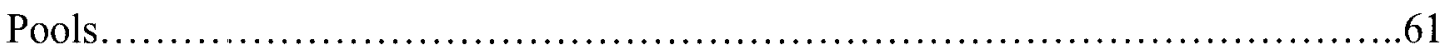

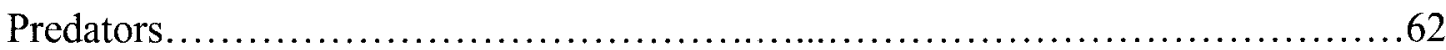

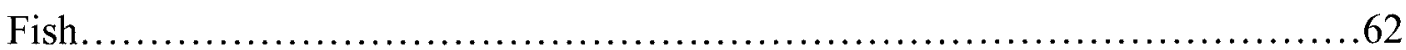

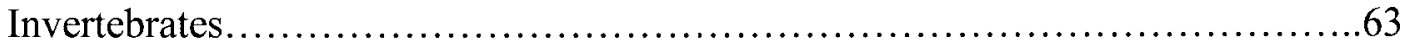

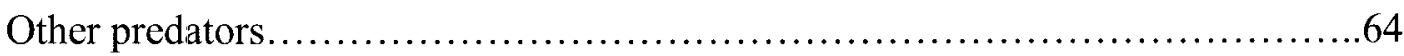

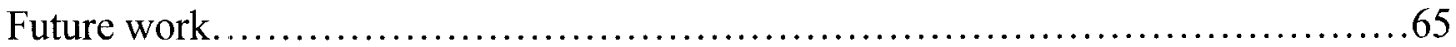

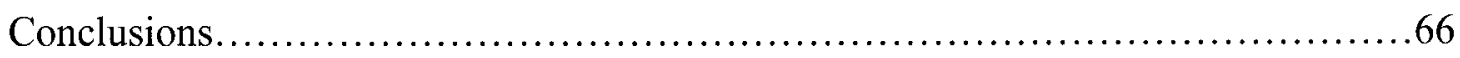

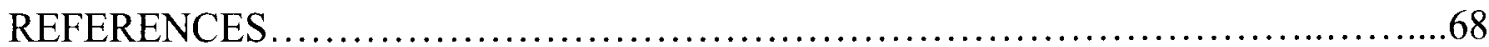

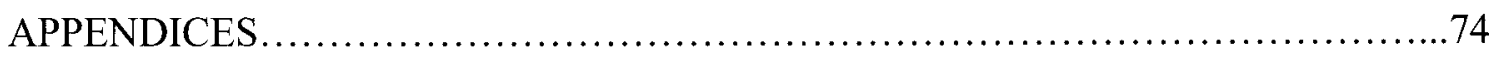

CURRICULUM VITAE............................................................ 77 


\section{LIST OF TABLES}

Table 1. Location and physical characteristics of the eleven ponds sampled in 2005 and 2006 at Bernheim Arboretum and Research Forest. BW = backwater.

Table 2. Eigenvalues for the four axes (AX 1-4) of the PCA ordination used to group ponds in terms of environmental factors and the scores of those physical and

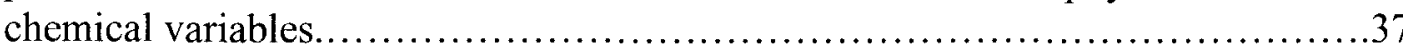

Table 3. Results of univariate analysis as part of a MANOVA test to determine differences in physical characteristics of backwater ponds $(n=6)$ vs. upland forest ponds $(\mathrm{n}=5)$

Table 4. Species richness at each pond in 2005 and 2006 at Bernheim Arboretum and Research Forest, Clermont, Kentucky. All records are eggs or larvae unless otherwise noted as adult (A). BW = backwater pond.

Table 5. Anuran species documented at Bernheim Arboretum and Research Forest, Clermont, Kentucky in 2005 and 2006 by call surveys conducted by Frogloggers of Bernheim Forest.............................................................. 48

Table 6. Shannon's diversity indices, direction of change from year to year, and net change in species richness for each pond sampled in 2005 and 2006 at Bernheim Arboretum and Research Forest, Clermont, Kentucky. BW = backwater pond......48

Table 7. Eigenvalues for the four axes (AX $1-4$ ) of the PCA ordination used in grouping ponds according to amphibian larval abundance and the species scores of those larvae. Ambystoma species includes A. maculatum and A. jeffersonianum....49

Table 8. Results of a linear regression test to determine correlation of pond characteristics with species richness and abundance (capture rate) at ponds. 


\section{LIST OF FIGURES}

Figure 1. Aerial view of the restoration of Wilson Creek at Bernheim Arboretum and Research Forest, Clermont, Kentucky. (Copyright Louisville Courier Journal. Used by permission.)

Figure 2. Location of Bernheim Arboretum and Research Forest, Clermont, Kentucky... 8

Figure 3. Maximum and minimum air temperatures on a daily basis over two years for Bernheim Arboretum and Research Forest, Clermont, Kentucky.

Figure 4. All ponds surveyed in 2005 and 2006 at Bernheim Arboretum and Research Forest, Clermont, Kentucky. Backwater pools = backwater ponds \#1-6

Figure 5. All ponds surveyed in 2005 and 2006 and their associated forest communities at Bernheim Arboretum and Research Forest, Clermont, Kentucky. In the legend, the first tree species listed is dominant followed by other major species found in the area. Backwater ponds $=$ backwater ponds $1-6$.

Figure 6. All ponds surveyed in 2005 and 2006 in association with geology at Bernheim Arboretum and Research Forest, Clermont, Kentucky. Backwater ponds =

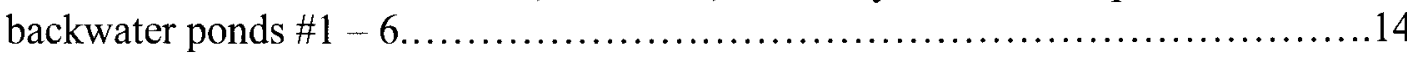

Figure 7. Positions used to take spherical densiometer readings in order to calculate percent canopy cover.

Figure 8. Percent of time that the ephemeral and semi-permanent pools surveyed were dry over two years of sampling. Pool \#10 and Pool \#15 never dried completely, but the other pools were ephemeral.

Figure 9. Principle component analysis (PCA) ordination depicting relationships among pond types and abiotic variables. The importance of an abiotic variable in grouping ponds together is represented by the length and direction of the arrows. $\mathrm{BW}=$ backwater pond. See Table 2 for explanation of other terms.......................36

Figure 10. Perimeter size averaged for each pond type sampled at Bernhcim Arboretum and Research Forest, Clermont, Kentucky. The difference is not significant.......38 
Figure 11. Maximum water depth averaged for each pond type sampled at Bernheim Arboretum and Research Forest, Clermont, Kentucky. The difference is not significant.

Figure 12. Distance from pond to forest edge averaged for each pond type sampled at Bernheim Arboretum and Research Forest, Clermont, Kentucky. The difference is significant.

Figure 13. Elevation averaged for each pond type sampled at Bernheim Arboretum and Research Forest, Clermont, Kentucky. The difference is significant.

Figure 14. Mean $\mathrm{pH}$ levels of two pond types sampled at Bernheim Arboretum and Research Forest, Clermont, Kentucky....

Figure 15. Mean conductivity levels of two pond types sampled at Bernheim Arboretum and Research Forest, Clermont, Kentucky ...............................41

Figure 16. Number of species documented in each of the ponds sampled in 2005 and 2006 at Bernheim Arboretum and Research Forest, Clermont, Kentucky. BW = backwater pond.

Figure 17. Average abundance (mean capture rate) of the backwater ponds in two amphibian breeding seasons at Bernheim Arboretum and Research Forest, Clermont, Kentucky

Figure 18. Principle component analysis (PCA) ordination depicting relationships among abundances of amphibian species and ponds sampled. The length of the arrow illustrates the strength in relationship to the pond toward which it is pointing. BW $=$ backwater pond. See Table 6 for explanation of other terms

Figure 19. Results of linear regression tests demonstrating that as $\mathrm{pH}$ and conductivity increase, A) species richness and B) capture rate (abundance) decreases. 


\section{INTRODUCTION}

As is the case for most threatened and endangered species, habitat loss (terrestrial and aquatic) is a major cause of the decline for amphibians (Beebee 1983, Corser 2001, Delis et al. 1996, Denton et al. 1997, Fellers and Drost 1993, Liu et al. 2004, Sax and Gaines 2003, Semlitsch 2000, Vallan 2000). Many other factors may negatively impact the amphibian community including ultraviolet radiation, predation, habitat modification, acidity and toxicants, diseases, climate change, and interactions of environmental factors. Numerous authors have investigated these factors, and Alford and Richards (1999) present a good review of these potential causes of amphibian decline. However, some believe that the "crisis" of declining amphibians is actually a result of major natural fluctuations in population structure (Alford and Richards 1999, Pechmann and Wilber 1994, Sarker 1996) and that the above factors may not be influencing amphibian

populations to a degree that would cause worldwide decline. Whichever the case, it is better to err on the side of caution and attempt to minimize or eliminate factors that could be contributing to amphibian decline. One way to achieve this is to restore or create wetlands as breeding habitat for amphibians.

Because section 404 of the Clean Water Act (U.S. EPA 1973) regulates the "discharge of dredged or fill material into the navigable waters" including wetlands, mitigation is required when wetlands are impacted or destroyed. Wetland creation and restoration gained popularity in the mid-1990s and have been used not only as mitigation, 
but also for educational programs (Biebighauser 2006, personal experience with $\mathrm{T}$. Biebighauser), with literature available to the general public on how to build a successful wetland (e.g., Biebighauser 2002). Wetlands increase biodiversity by housing many taxa in addition to amphibians (aquatic and semi-aquatic plants, insect larvae and adults, and crustaceans) and they are important food and water sources for many others (e.g., waterfowl, mammals and reptiles). One critical concern is whether created wetlands contain the same species as the natural wetlands they replace. When created wetlands are colonized naturally they generally do not contain as many as the same species as historical wetland areas (Lehtinen and Galatowitsch 2001, Pechmann et al. 2001; see however Petranka et al. 2003a, Petranka et al. 2003b). Even when amphibians are purposely introduced to new wetlands, these areas still lag behind historic wetlands in species richness (Dodd and Seigel 1991, see however Denton et al. 1997).

One of the obstacles to creating successful new wetlands for the support of amphibians is that many varied factors influence amphibian species (Mitsch and Wilson 1996, Montalvo et al. 1997, Semlitsch 2000, Semlitsch 2002). For example, important factors in determining the amphibian assemblage at a given location include hydroperiod (Semlitsch and Bodie 1998, Snodgrass et al. 2000a, Snodgrass et al. 2000b), canopy cover (Skelly et al. 1999, Vasconcelos and Calhoun 2004), the presence or absence of fish and other predators (fish: Hecnar and M'Closkey 1997, Hero et al. 2001, Kats et al. 1988; other predators: Morin 1987, Wassersug and Sperry 1977, Woodward 1983), the invertebrate community (Morin et al. 1988, Smith 1983), wetland size (Semlitsch and Bodie 1998), the proximity to forested terrestrial habitat (deMaynadier and Hunter 1998, Vallan 2000, Vasconcelos and Calhoun 2004), competition (Alford and Wilber 1985, 
Morin 1987, Morin et al. 1988, Wilber and Alford 1985) or, most commonly, a combination of several of these factors (Brodman et al. 2003, Hecnar and M'Closkey 1998, Skelly et al. 1999, Snodgrass et al. 2000b, Wilber 1987). Even if all of these factors could be addressed appropriately when building a new wetland, the success of many restoration projects is not known because they are monitored for relatively short amount of time. How long a created or restored wetland should be monitored before it can be deemed a success has been debated. The funding for post-monitoring of mitigation projects usually lasts between three and five years (Petranka et al. 2003a, Petranka et al. 2003b), but most researchers have found that it is difficult to determine success in that span of time. Even for species that colonize a new wetland rapidly (i.e., within a few months; Lehtinen and Galatowitsch 2001), stable breeding populations may not be established for several years. Some species such as Rana catesbeiana (bullfrogs) and occasionally $R$. clamitans (green frogs) and $R$. sphenocephala (southern leopard frogs) can take two years or more to metamorphose, much less reach sexual maturity. Therefore determining whether a breeding population for such species is stable is not possible in 2-3 years after wetland creation. Still, some have claimed that in 2-3 years the species richness of a created wetland equals that of a reference wetland (Petranka et al. 2003b). However, Semlitsch (2002) determined that 5-6 years should pass before a restoration is considered successful, and a growing number of researchers are beginning to suggest that more than 5 years are needed (Gibbs et al. 1998, Marsh 2001, Mitsch and Wilson 1996, Pechmann et al. 2001, Petranka et al. 2003a). This discrepancy in monitoring period is in part due to the geographic location in which a particular wetland restoration is constructed, the species being evaluated, and the definition of success, but it 
is becoming clear that natural fluctuations in amphibian populations and their existence as metapopulations must be considered when declaring success or failure of a mitigation/restoration project (Arntzen and Teunis 1993, Gill 1978, Marsh 2001, Marsh and Trenham 2001, Pechmann and Wilber 1994, Pulliam 1988).

Restoration projects that are not specifically intended to attract amphibians per se can still create suitable amphibian breeding habitat. In the case of this study, the restoration of Wilson Creek flowing through Bernheim Arboretum and Research Forest in central Kentucky (Figure 1) resulted in the creation of seven still-water ponds that had not existed before. As stated in the project workplan for the restoration, "The overall objective of the project is to demonstrate techniques to improve water quality in streams draining human-altered lands in central Kentucky" (Shea 2000). The creation of new habitat provided an excellent opportunity to observe the natural colonization process by amphibians without manipulation or introduction. Amphibians readily utilize available water for breeding regardless of the reason for the habitat creation (Pechmann et al. 2001, personal observation), so even though the backwater ponds were not created specifically for amphibian use, I predicted that they would use it.

The main objective of this study was to observe the early natural colonization by amphibians of new backwater pond habitat as part of evaluating the success of a stream restoration project. A further objective was to observe how amphibian assemblages change as new backwater ponds age. This study also provides a baseline for comparison with amphibian communities of the backwater ponds in the future. Data collection took place over the course of two amphibian breeding seasons (February - July) in 2005 and 


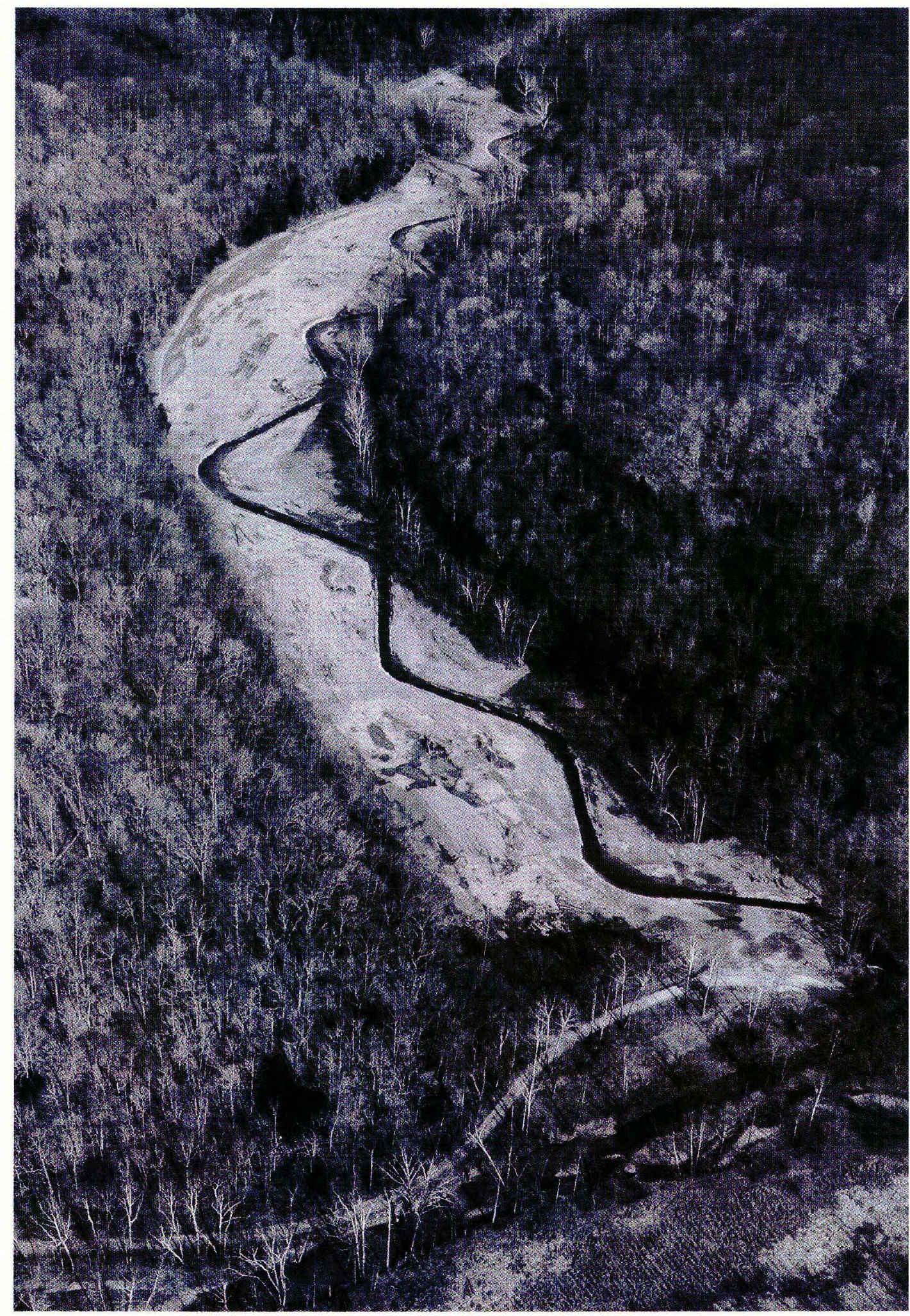

Figure 1. Aerial view of the restoration of Wilson Creek at Bernheim Arboretum and Research Forest, Clermont, Kentucky. (Copyright Louisville Courier Journal. Used by permission.) 
2006. Amphibian diversity and abundance were compared between the six new backwater ponds intermittantly connected to the stream and five established upland forest ponds. Data were collected on the physical and chemical characteristics of the ponds in order to corrlate differences in the habitat characteristics of the backwater ponds and the upland forest ponds with the amphibian assemblages found in these ponds. Fifteen ephemeral pools also created as part of the stream restoration were monitored for amphibian species richness only, and no physical or chemical characteristics were measured. Two hypotheses were tested: 1) the species richness and abundance is greater in the older, upland ponds than in the new, lowland backwater ponds; 2) the species richness and abundance will increase in the backwater ponds over time. 


\section{METHODS}

\section{Study Area}

This study was conducted at Bernheim Arboretum and Research Forest located in Bullitt and Nelson Counties approximately $48 \mathrm{~km}(30$ miles) south of Louisville near Clermont, Kentucky ( $37^{\circ} 55^{\prime} 47^{\prime \prime} \mathrm{N}, 85^{\circ} 39^{\prime} 0^{\prime \prime} \mathrm{W}$; Figure 2.). Historically, the land was heavily logged and farmed by European settlers before it was purchased by Isaac W. Bernheim and given to the state of Kentucky as a gift for recreation and education. The property was established on 10 May 1929 and is a 5666 ha plot of land that has 4856 ha set aside specifically for research. The remaining property is dedicated to recreational activities and the arboretum. The Forest is located in the Knobs physiographic region of the state, and the topography is hilly ranging in elevation from $139-288 \mathrm{~m}$. The property is largely forested and is surrounded by forest and rural small-scale agriculture and livestock farmland.

The property is comprised of six different forest communities representing a variety of habitat types: 1) chestnut oak (Quercus prinus) mixed with white oak ( $Q$. alba), southern red oak ( $Q$. falcata), northern red oak $(Q$. rubra) and black oak $(Q$. velutina); 2) black oak - white oak with some scarlet oak ( $Q$. coccinea); 3) chinkapin oak (Q. muehlenbergii) with some sugar maple (Acer saccharum); 4) American beech (Fagus grandifolia) and sugar maple with some tulip poplar (Liriodendron tulipifera); 
5) Virginia pine (Pinus virginiana); and 6) sycamore (Platanus occidentalis) mixed with sweetgum (Liquidambar styraciflua) and tulip poplar. A seventh vegetation type is made up of eastern red cedar (Juniperus virginiana) along with little bluestem (Schizachyrium scoparium) and sideoats grama (Bouteloua curtipendula) grasses (Homoya 1999).

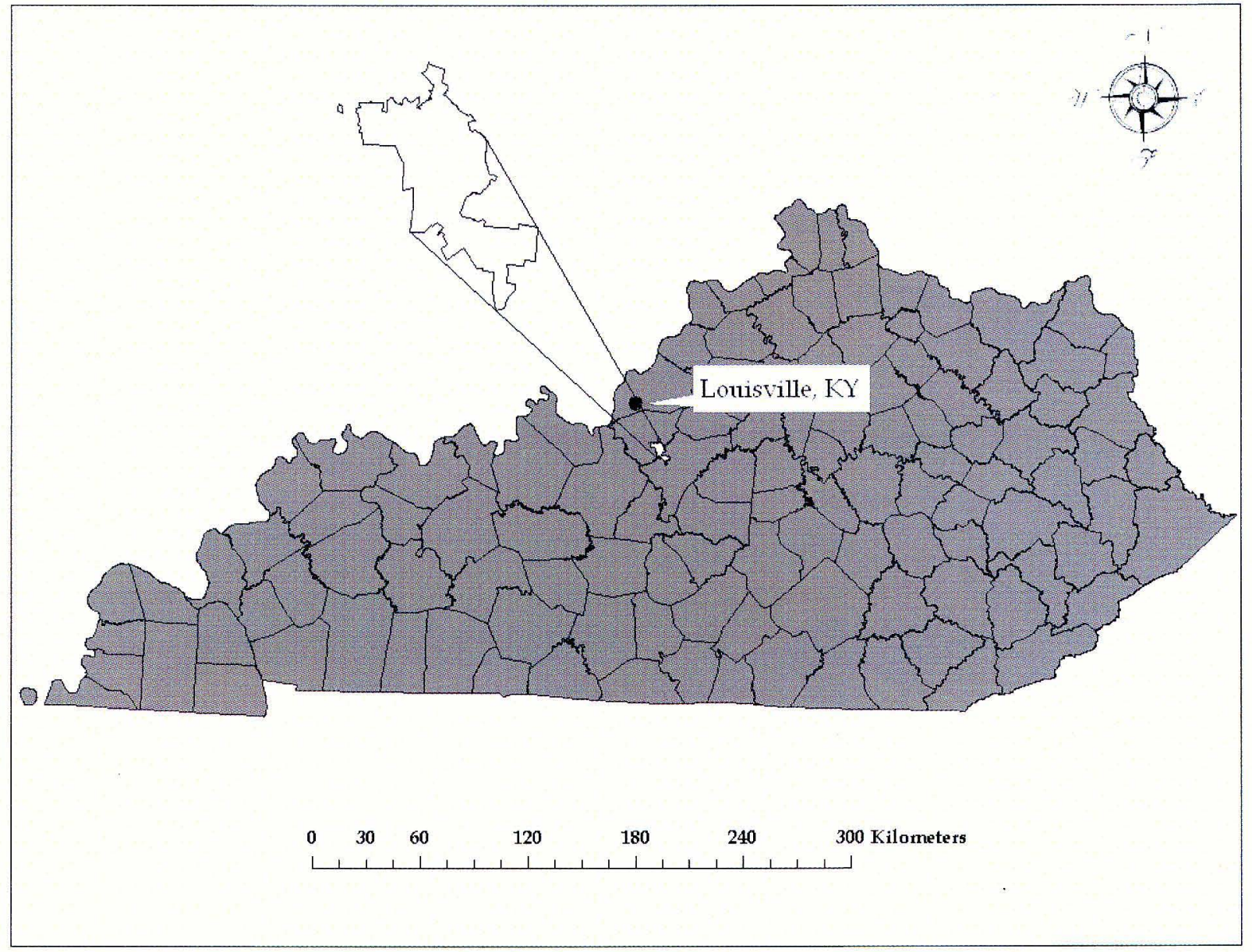

Figure 2. Location of Bernheim Arboretum and Research Forest, Clermont, Kentucky.

Weather in both years was typical of the region. In 2005, air temperatures ranged from a low of $-7.2^{\circ} \mathrm{C}\left(19^{\circ} \mathrm{F}\right)$ in February to a high of $35^{\circ} \mathrm{C}\left(95^{\circ} \mathrm{F}\right)$ in July. In 2006 , the lowest temperature was in February at $-15.6^{\circ} \mathrm{C}\left(4^{\circ} \mathrm{F}\right)$ and the highest was in July at $33.3^{\circ} \mathrm{C}$ 
$\left(92^{\circ} \mathrm{F}\right.$; University of Kentucky Agricultural Weather Center 2006). The trend in air temperature was similar in both years overall (Figure 3).
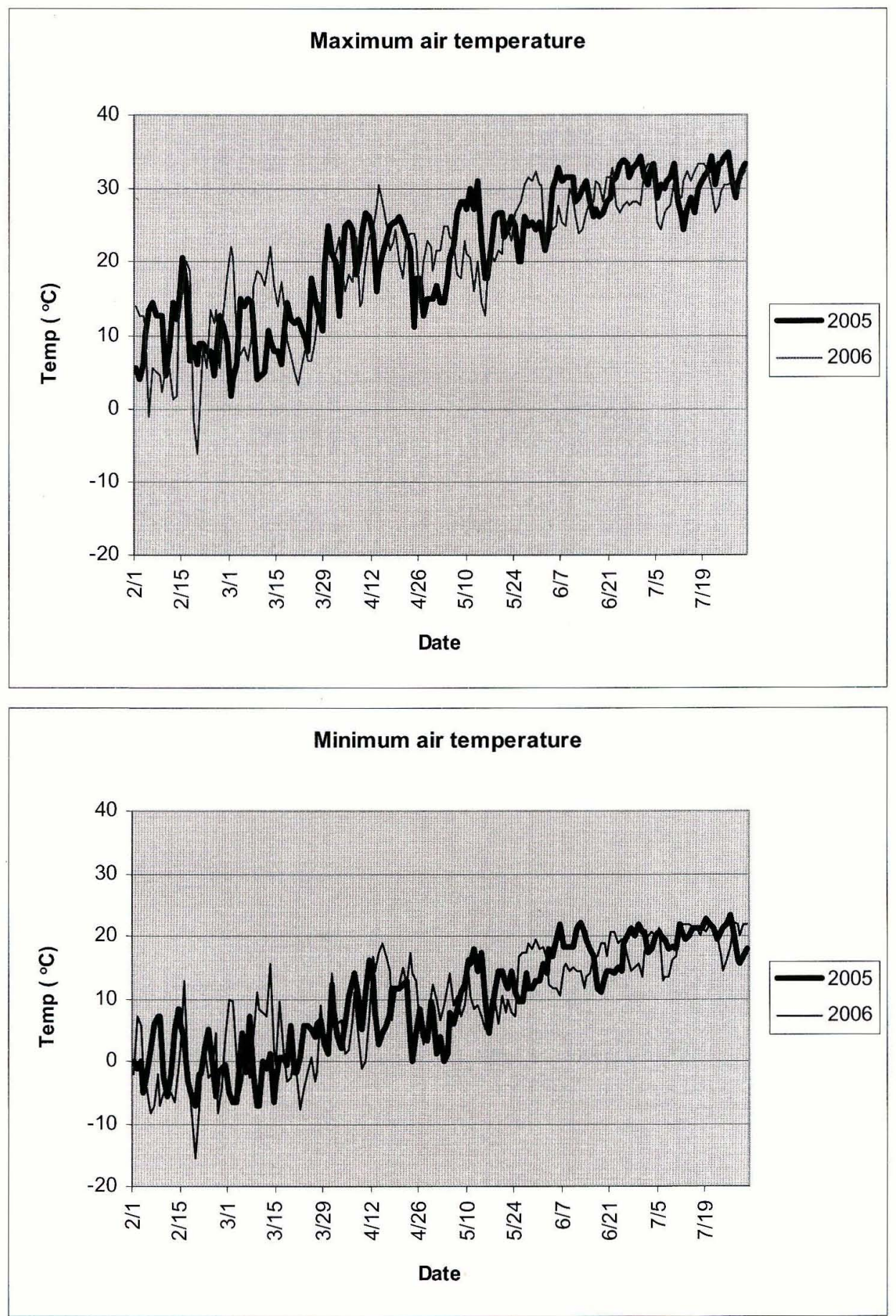

Figure 3. Maximum and minimum air temperatures on a daily basis over two years for Bernheim Arboretum and Research Forest, Clermont, Kentucky. 
Bernheim Forest contains both natural and artificially constructed bodies of water. There are six streams running through the property and 26 ponds have been mapped. The six backwater ponds on which this study focused were all located at a forest edge beside a field. For comparison with these ponds, well-established ponds created in the 1970s were selected based on their being similarly located near a forest edge. Three upland forest ponds were selected in 2005 , but no fish were documented in two of these ponds while all of the backwater ponds had fish present. Fish can be significant predators of amphibians, so in order to reduce differences between the backwater ponds and the upland forest ponds, the two fishless ponds were not surveyed and two similar ponds with fish were added in 2006. Thus in each year, all six backwater ponds and three established ponds were sampled, but two of the ponds sampled in 2005 were not the same ones sampled in 2006. A total of 11 ponds were sampled in two years (Figure 4).

\section{Pond descriptions}

Table 1 summarizes the physical characteristics of the ponds studied. The five established upland ponds are in the mixed-oak forest types (Figure 5) characterized by acidic soil (Figure 6) and high moisture content retained because of being located on flat ridgetops. These ponds are at elevations ranging from $230-260 \mathrm{~m}$. The understory in this area is dominated by greenbrier (Smilax sp.) and spicebush (Lindera benzoin).

The backwater ponds are at a lower elevation $(152-155 \mathrm{~m})$ and are at the edge of the sycamore forest type and chinquapin oak forest type (Figure 5) where the soils are alkaline (Figure 6). Other tree species in this area include sugar maple, various ash 


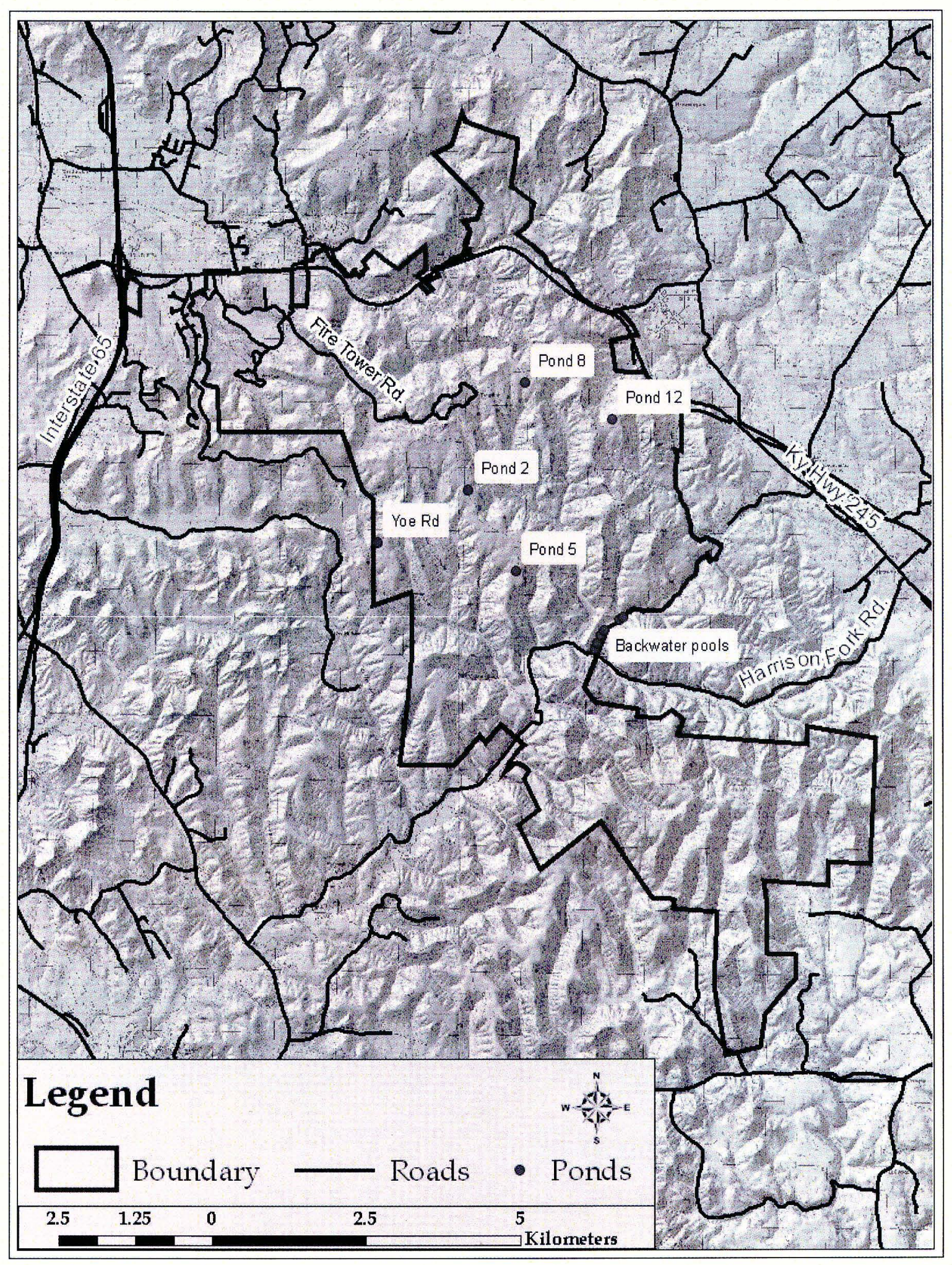

Figure 4. All ponds surveyed in 2005 and 2006 at Bernheim Arboretum and Research Forest, Clermont, Kentucky. Backwater pools = backwater ponds \#1-6. 
Table 1. Location and physical characteristics of the eleven ponds sampled in 2005 and 2006 at Bernheim Arboretum and Research Forest. BW = backwater pond.

\begin{tabular}{|c|c|c|c|c|c|c|c|}
\hline \multirow{2}{*}{$\begin{array}{l}\text { Pond } \\
\text { name }\end{array}$} & \multicolumn{2}{|c|}{ Coordinates } & \multirow{2}{*}{$\begin{array}{l}\text { Perimeter } \\
\text { (m) }\end{array}$} & \multirow{2}{*}{$\begin{array}{c}\text { Max. } \\
\text { water } \\
\text { depth } \\
(\mathrm{cm})\end{array}$} & \multirow{2}{*}{$\begin{array}{c}\text { Distance } \\
\text { to edge } \\
\text { (m) }\end{array}$} & \multirow{2}{*}{$\begin{array}{l}\text { Elevation } \\
\text { (m) }\end{array}$} & \multirow{2}{*}{$\begin{array}{c}\text { Canopy } \\
\text { cover }\end{array}$} \\
\hline & Latitude & Longitude & & & & & \\
\hline BW1 & $37^{\circ} 52^{\prime} 12^{\prime \prime}$ & $85^{\circ} 35^{\prime} 58^{\prime \prime}$ & 167.6 & 38 & 10.0 & 152 & $88.8 \%$ \\
\hline BW2 & $37^{\circ} 52^{\prime} 16^{\prime \prime}$ & $85^{\circ} 35^{\prime} 57^{\prime \prime}$ & 206.6 & 55 & 11.7 & 152 & $88.4 \%$ \\
\hline BW3 & $37^{\circ} 52^{\prime} 20^{\prime \prime}$ & $85^{\circ} 35^{\prime} 54^{\prime \prime}$ & 298.8 & 65 & 10.4 & 152 & $93.2 \%$ \\
\hline BW4 & $37^{\circ} 52^{\prime} 23^{\prime \prime}$ & $85^{\circ} 35^{\prime} 52^{\prime \prime}$ & 60.0 & 78 & 0.0 & 152 & $71.4 \%$ \\
\hline BW5 & $37^{\circ} 52^{\prime} 28^{\prime \prime}$ & $85^{\circ} 35^{\prime} 42^{\prime \prime}$ & 100.8 & 38 & 0.0 & 155 & $79.9 \%$ \\
\hline BW6 & $37^{\circ} 52^{\prime} 29^{\prime \prime}$ & $85^{\circ} 35^{\prime} 44^{\prime \prime}$ & 33.9 & 37 & 0.0 & 155 & $84.4 \%$ \\
\hline Pond \#5 & $37^{\circ} 52^{\prime} 53^{\prime \prime}$ & $85^{\circ} 36^{\prime} 51^{\prime \prime}$ & 73.6 & 75 & 19.1 & 255 & $92.1 \%$ \\
\hline Pond \#8 & $37^{\circ} 54^{\prime} 30^{\prime \prime}$ & $85^{\circ} 36^{\prime} 45^{\prime \prime}$ & 41.3 & 30 & 18.3 & 253 & $75.8 \%$ \\
\hline Yoe Rd. & $37^{\circ} 53^{\prime} 08^{\prime \prime}$ & $85^{\circ} 38^{\prime} 23^{\prime \prime}$ & 60.0 & 100 & 31.0 & 230 & $81.8 \%$ \\
\hline Pond \#2 & $37^{\circ} 53^{\prime} 35^{\prime \prime}$ & $85^{\circ} 37^{\prime} 22^{\prime \prime}$ & 48.7 & 100 & 20.5 & 243 & $84.7 \%$ \\
\hline Pond \#12 & $37^{\circ} 54^{\prime} 11^{\prime \prime}$ & $85^{\circ} 35^{\prime} 46^{\prime \prime}$ & 57.0 & 150 & 35.2 & 260 & $71.0 \%$ \\
\hline
\end{tabular}

species (Fraxinus sp.), Ohio buckeye (Aesculus glabra), and black walnut (Juglans nigra; Bernheim Arboretum and Research Forest 2006). Water levels dropped through the summers in all ponds, but none dried completely. Therefore, all bodies of water sampled were permanent over the two-year period of this study.

A field assistant and I measured physical characteristics of the ponds in September of both years. Water levels do not vary much due to limited rainfall at this time of year, and amount of canopy cover can still be determined. Factors measured were perimeter size, distance to the forest edge, maximum water depth, and average percent canopy cover. Perimeter and distance to the edge of the woods were measured with a standard 100 -meter measuring tape. We measured water depth with a line-andpulley system with a rope stretched across the pond and a person holding each end. 


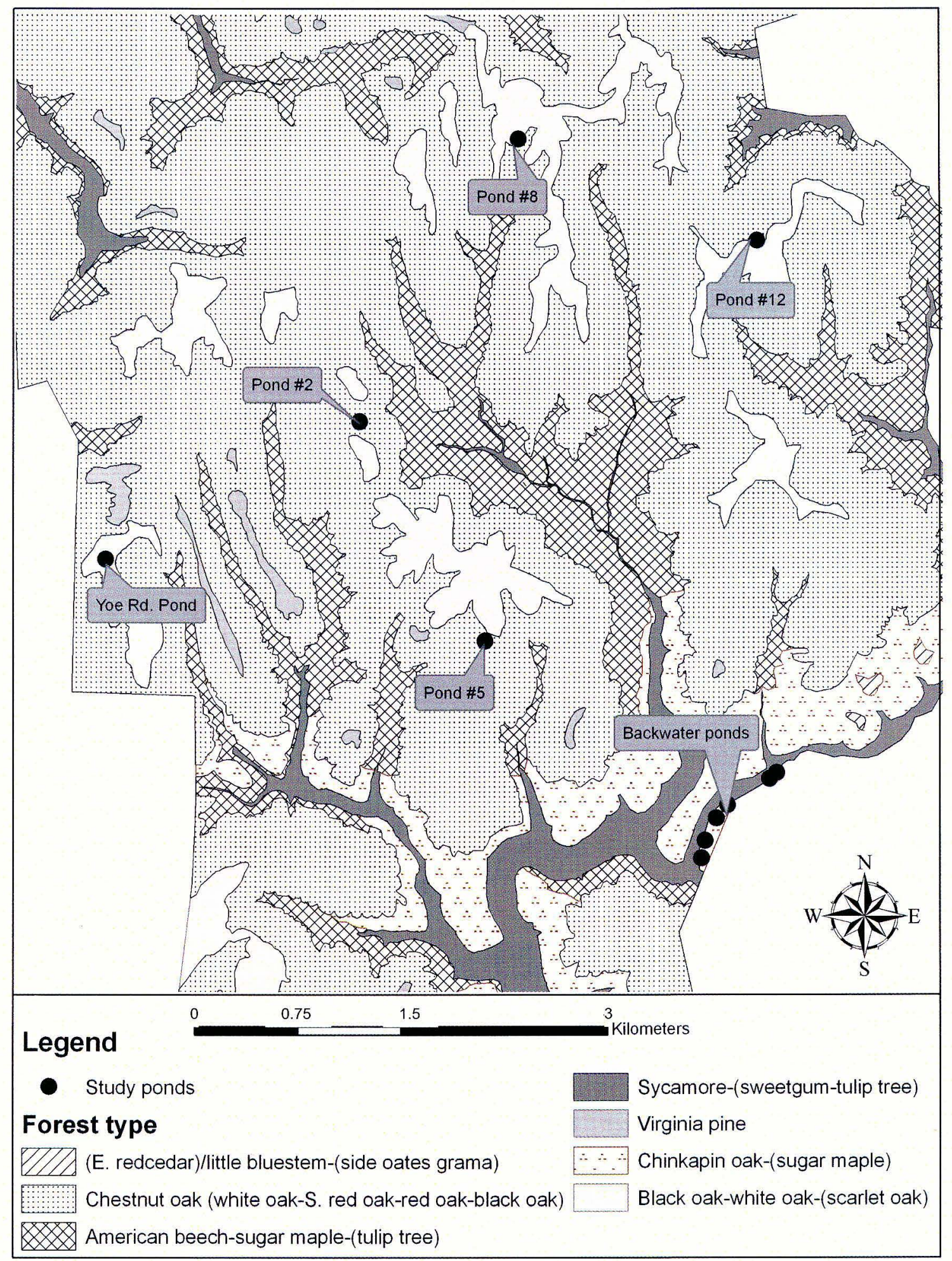

Figure 5. All ponds surveyed in 2005 and 2006 and their associated forest communities at Bernheim Arboretum and Research Forest, Clermont, Kentucky. In the legend, the first tree species listed is dominant followed by other major species found in the area. Backwater ponds = backwater ponds $1-6$. 


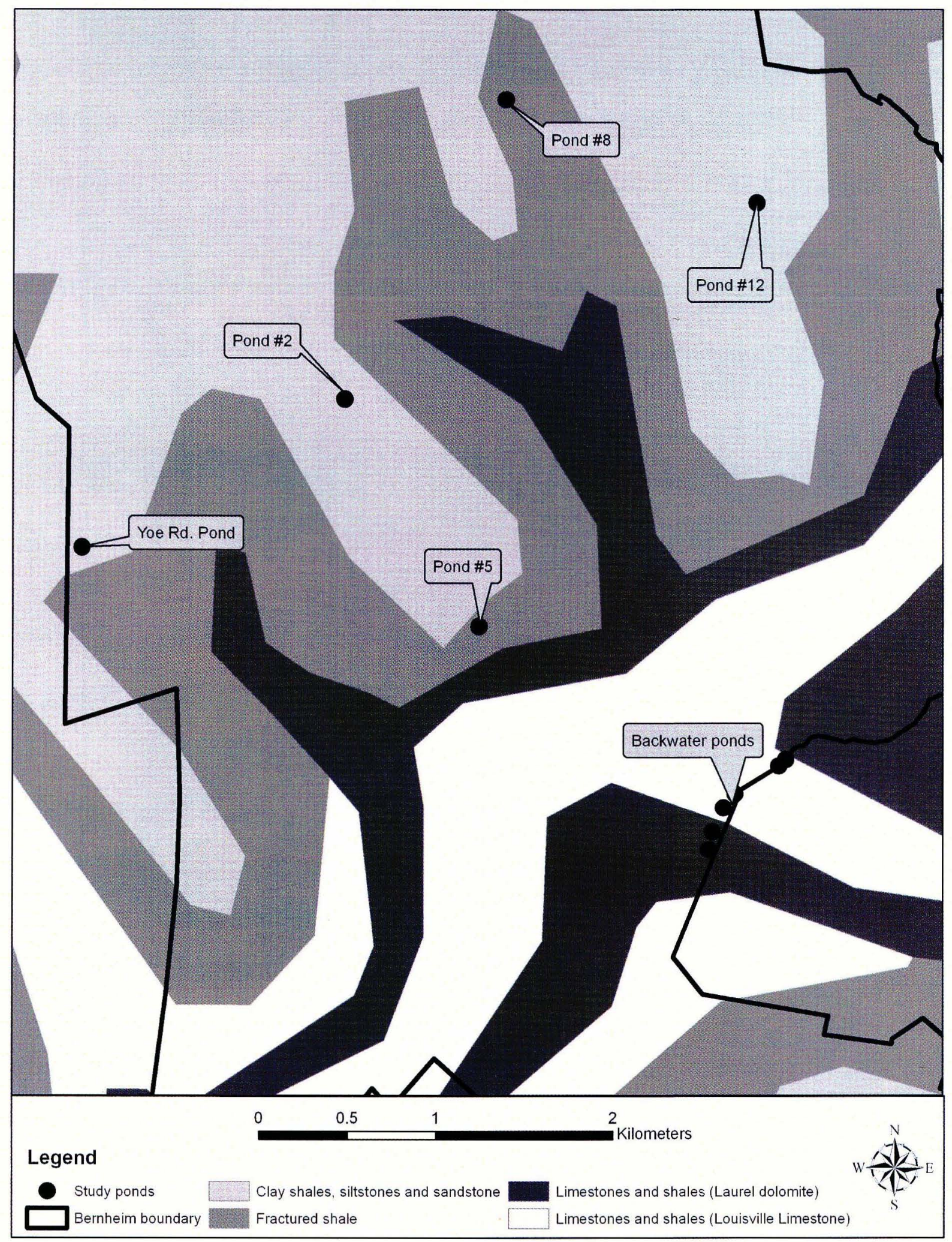

Figure 6. All ponds surveyed in 2005 and 2006 in association with geology at Bernheim Arboretum and Research Forest, Clermont, Kentucky. Backwater ponds = backwater ponds \#1 -6 . 
A weight was anchored to a rope (subdivided by $0.1 \mathrm{~m}$ markings) to aid in descending it into the water (designed by C. Byers). We took least three depth readings to find the deepest section of the pond. I determined canopy cover with a spherical densiometer. I took one reading while standing on the "edge" side of the pond, while a second value was recorded standing directly across the widest part of the pond on the "forest" side (Figure 7). These values were then averaged to give one canopy cover reading per pond.

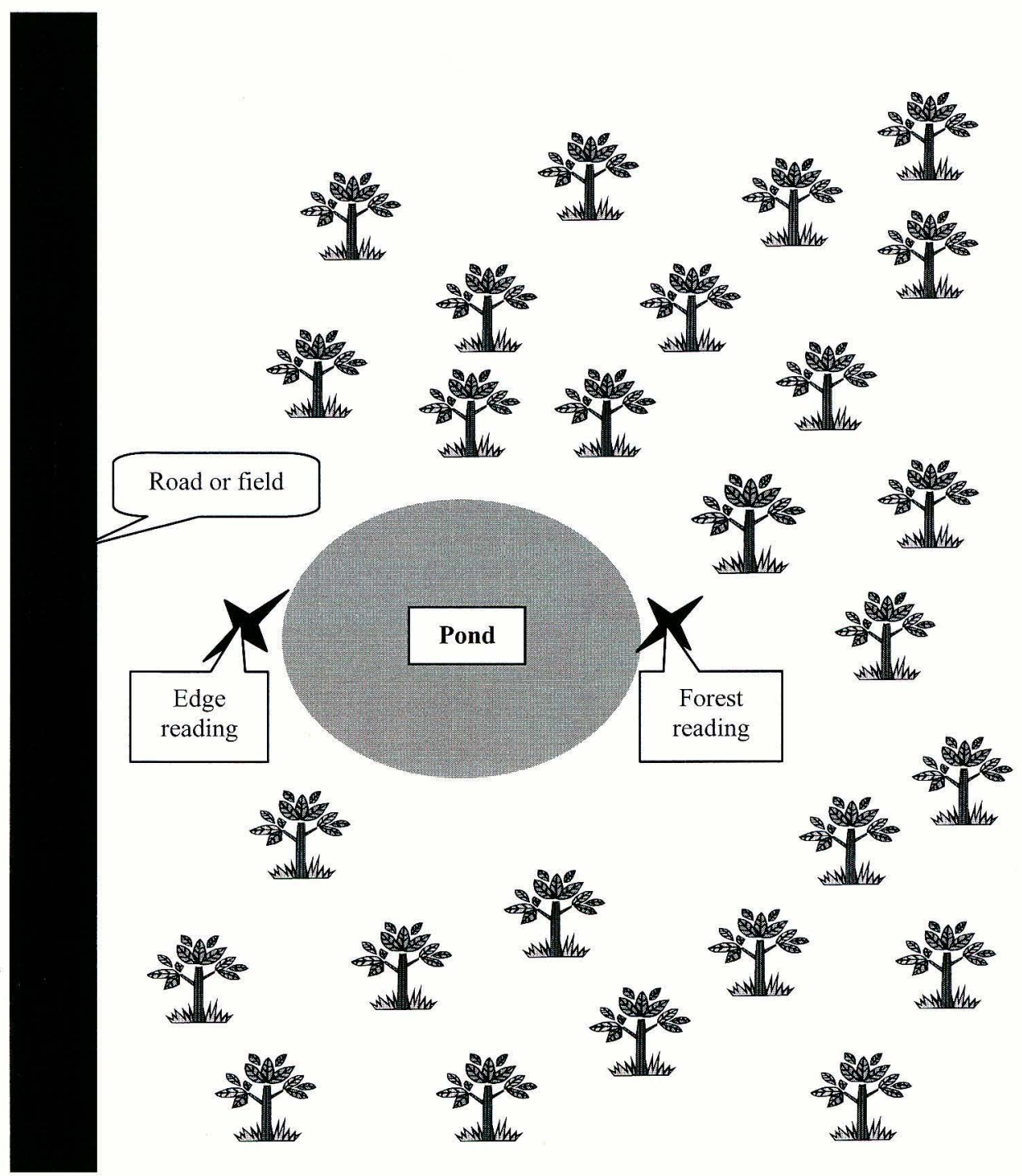

Figure 7. Positions used to take spherical densiometer readings in order to calculate percent canopy cover. 
We also monitored small pools (most of them ephemeral) located on both sides of the redirected Wilson Creek for species richness as part of monitoring the success of the stream restoration. Theses pools are along the same elevation gradient as the backwater ponds, but because they are mostly situated in the open field, they are not strongly associated with particular tree species.

\section{Upland Forest Ponds}

The upland forest ponds were created in the 1970s for fire suppression and for wildlife use (Ronnie Moore, Natural Areas Technician at Bernheim Forest, personal communication). The ponds used in this study are all very similar in shape (approximately round) and distance to the edge of the forest. The water levels of the ponds vary moderately (range: $30-150 \mathrm{~cm}$ ), and the substrate of all the ponds is silt and detritus. The shallow north end of Yoe Rd. Pond contained cattails (Typha latifolia), but none of the other ponds had emergent vegetation. All ponds contained layers of leaf litter contributed by surrounding deciduous trees. Even though some of the ponds were thought to have fish, only Yoe Rd. Pond actually had fish documented, and then only in 2005. All roads mentioned are gravel, limited access fire roads. 


\section{Yoe Rd. Pond}

This pond was sampled in both years and is located at the end of Yoe Road at the western boundary of the property at an elevation of $230 \mathrm{~m}$. The road is $31 \mathrm{~m}$ north of the pond and an open field is $47.5 \mathrm{~m}$ southeast of the pond. The length of the perimeter is 60 $\mathrm{m}$ and the maximum water depth is $1 \mathrm{~m}$. The pond is partially shaded with $81.8 \%$ canopy cover, but the middle of the pond gets generous amounts of sunlight. Tree species surrounding the pond in decreasing numbers are white oak, red maple (Acer rubrum), chinkapin oak, Virginia pine, flowering dogwood (Cornus florida), persimmon (Diospyros virginiana), black gum (Nyssa sylvatica), and scarlet oak.

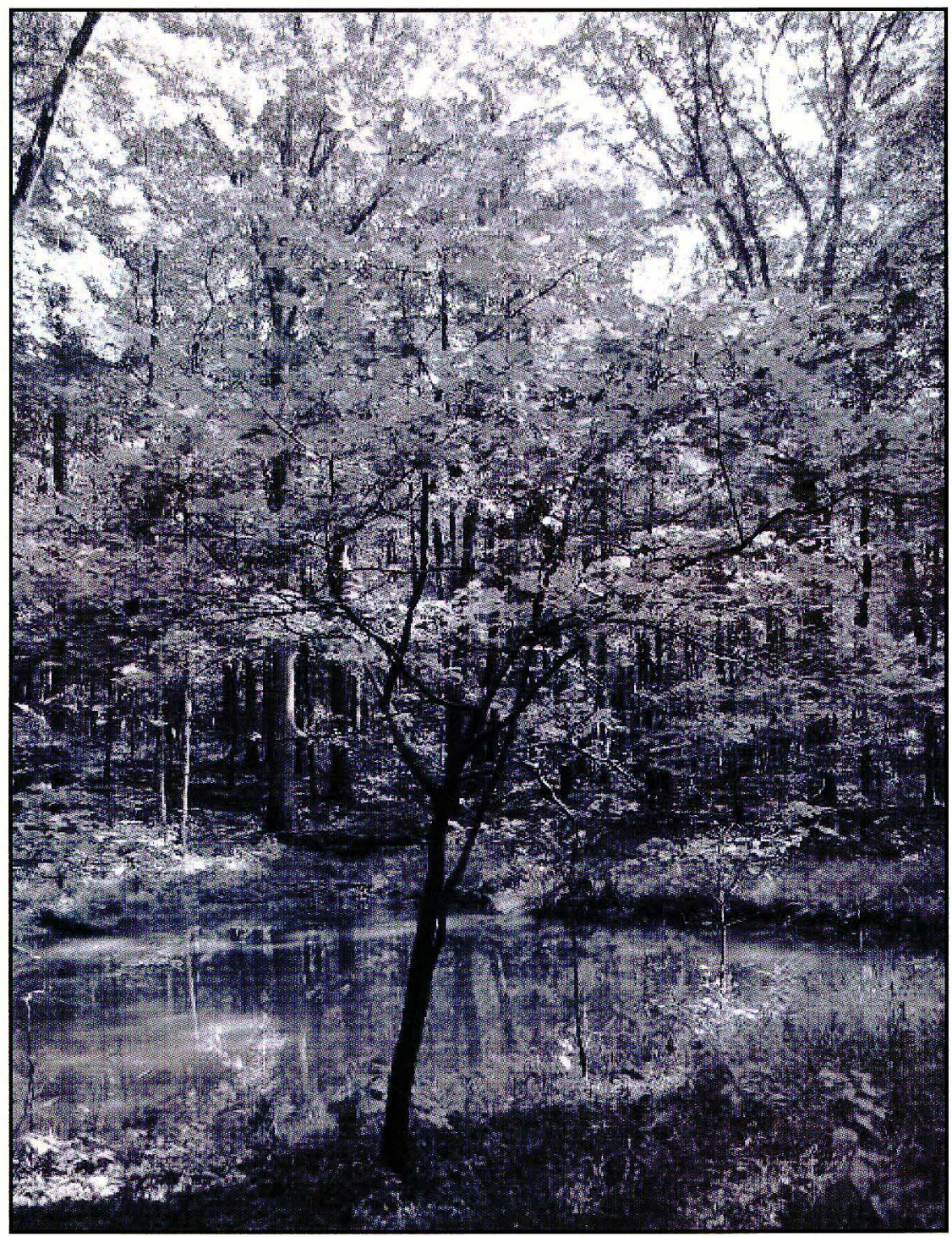




\section{Pond \#5}

Pond \#5 was surveyed only in 2005 . It is located down a firebreak trail west of Wilson Creek Fire Road at an elevation of $244 \mathrm{~m}$ and is $19 \mathrm{~m}$ from a wildlife opening field. The pond is $76.3 \mathrm{~m}$ in circumference and the maximum water depth is $75 \mathrm{~cm}$. This pond has $92.1 \%$ canopy cover, and even the middle of the pond gets very little sunlight. The most common tree species is red maple followed by white oak, chestnut oak, American beech, sassafras (Sassafras albidum), pignut hickory (Carya glabra), persimmon, and eastern hophornbeam (Ostrya virginiana).

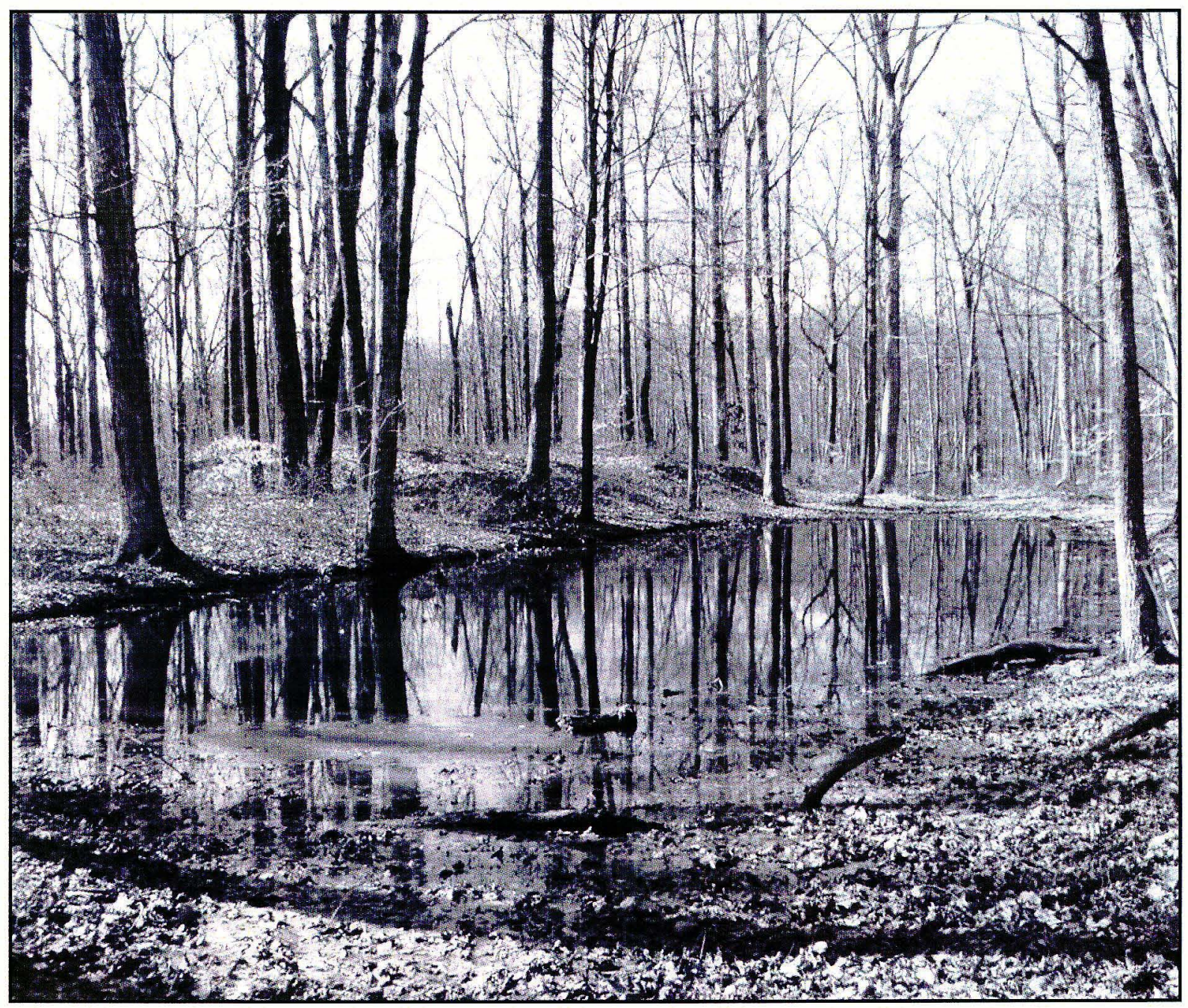




\section{Pond \#8}

This pond was also only surveyed in 2005 and is located through a field south of Ashlock Hollow Road It is located on a gentle slope at an elevation of $253 \mathrm{~m}$. The edge of the forest is $18.3 \mathrm{~m}$ north of the pond, the perimeter is $41.3 \mathrm{~m}$ in circumference, and the maximum water depth is only $30 \mathrm{~cm}$. As mentioned above, the substrate of the pond is silt and detritus but in this case, it is quite a bit deeper than the water itself. With only $75.8 \%$ canopy cover, the pond gets a good deal of sunlight. This pond is different than the others in that it contains anthropogenic garbage. This pond is heavily surrounded by white oak, including many understory saplings of this species. Other tree species include red maple, persimmon, honey locust (Gleditsia triacanthos), mockernut hickory (Carya tomentosa), American beech, eastern redcedar, and black cherry (Prunus serotina).

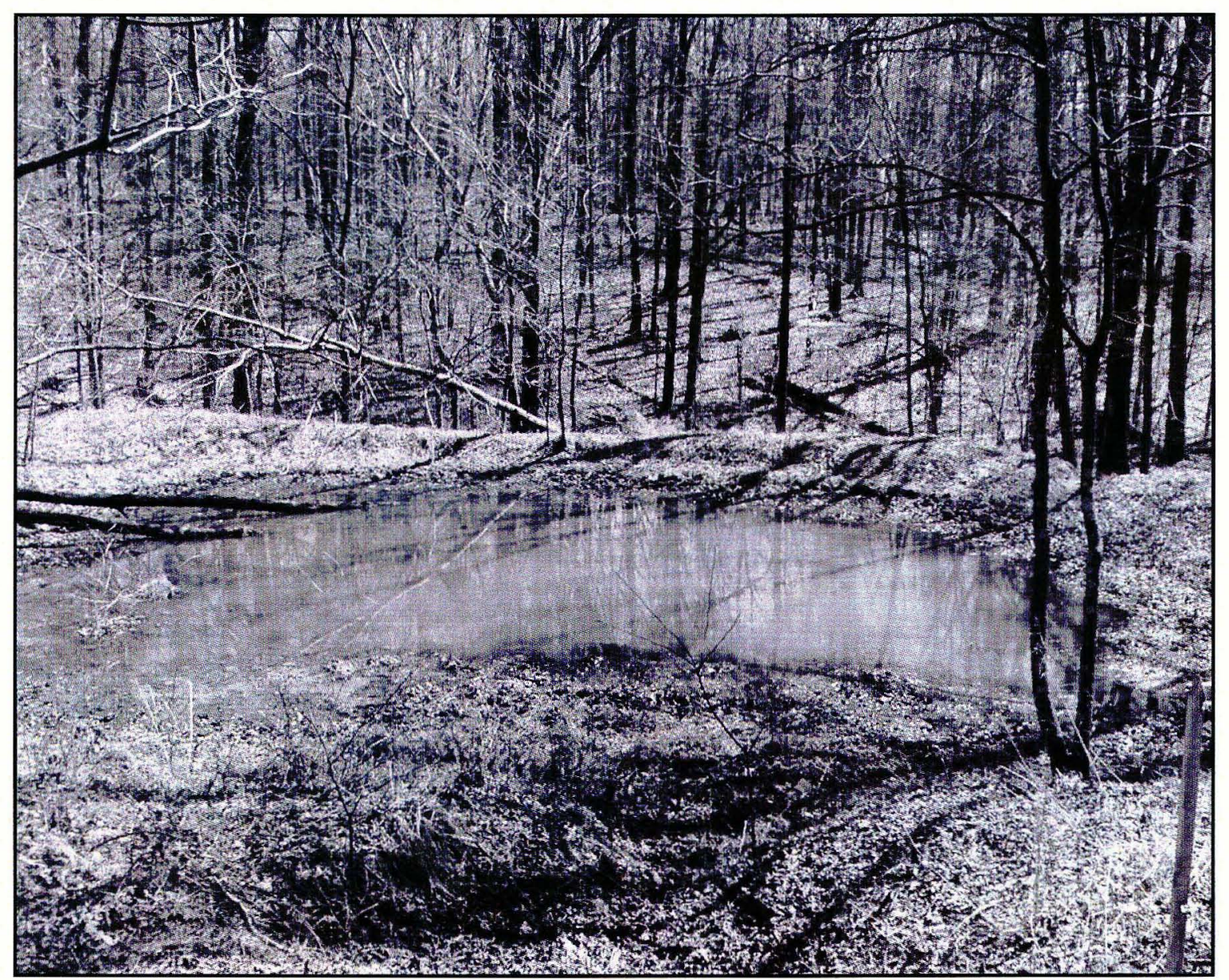




\section{Pond \#2}

I selected Pond \#2 to be surveyed in 2006 because it was thought to contain fish. It is located just off Wilson Creek Fire Road on the ridgetop at an elevation of $243 \mathrm{~m}$. The perimeter measures $48.7 \mathrm{~m}$ in circumference and the pond is $20.5 \mathrm{~m}$ from the edge of the forest. The maximum water depth is $1 \mathrm{~m}$ and it is moderately shaded $(84.7 \%$ canopy cover). The north end of the pond gets quite a bit of sunlight, but the south edge is moderately to heavily shaded. The most common tree species is white oak followed by sugar maple, pignut and shagbark (Carya ovata) hickories, flowering dogwood, American beech, and black cherry.

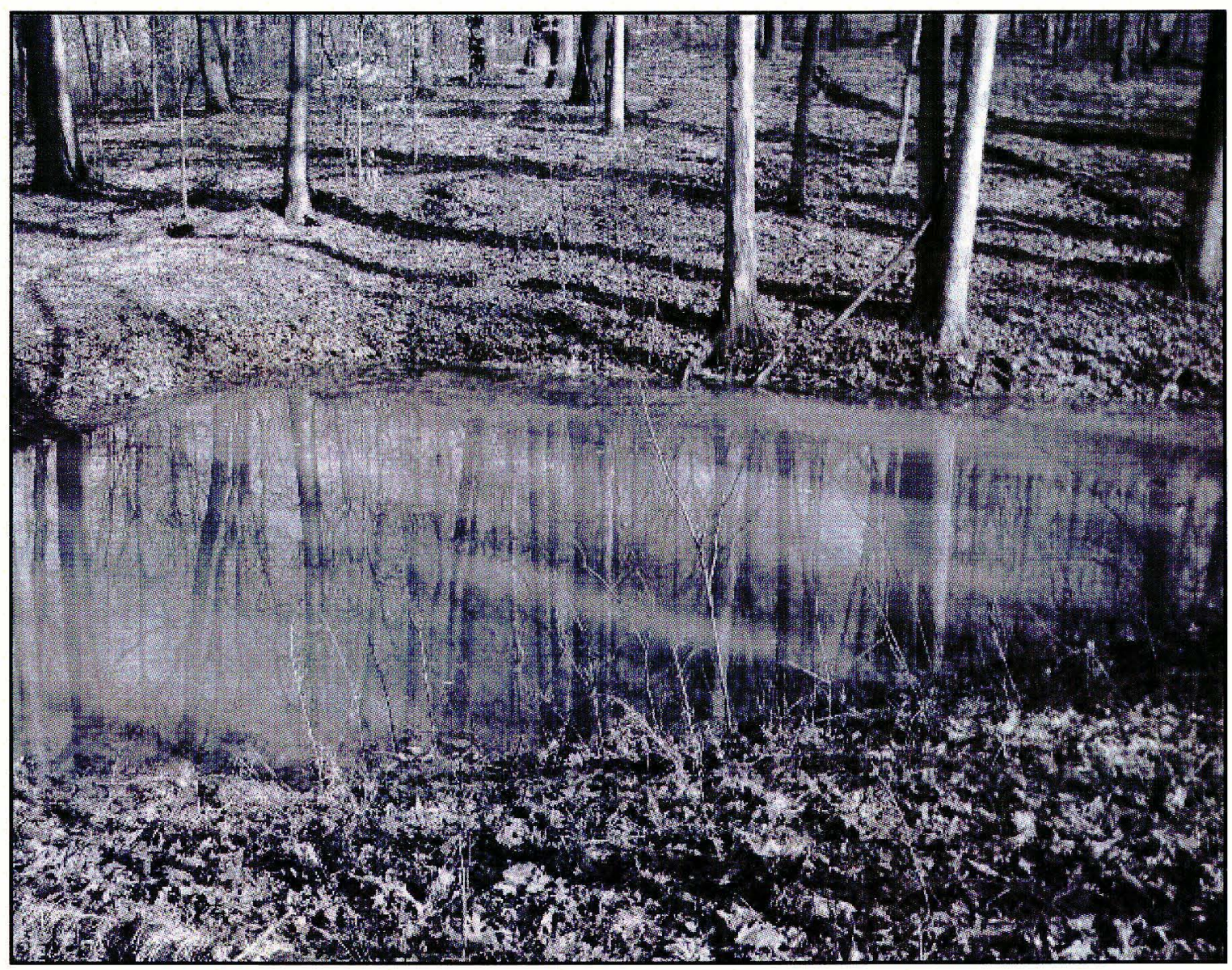




\section{Pond \#12}

I selected this pond to be surveyed in 2006 also because it was thought to contain fish. It is located east of Pond \#8 along Ashlock Hollow Road and is $35.2 \mathrm{~m}$ from the edge of the forest. It is at the highest elevation of any of the ponds at $260 \mathrm{~m}$. The perimeter of the pond is $57 \mathrm{~m}$ and the maximum water depth is $1.5 \mathrm{~m}$. A large chestnut oak is down across the pond with the majority of the crown sticking out of the water. The trees around the pond are not very close to the edge, and canopy cover is the lowest of all the ponds $(71.0 \%)$ with the north end receiving the most solar radiation. As with Pond \#2, the south side is moderately to heavily shaded. Mostly chestnut oak surrounds the pond, with some white oak and sugar maple also present. Other tree species include winged elm (Ulmus alata), pawpaw (Asimina triloba), green ash (Fraxinus pennsylvanica), and sassafras.

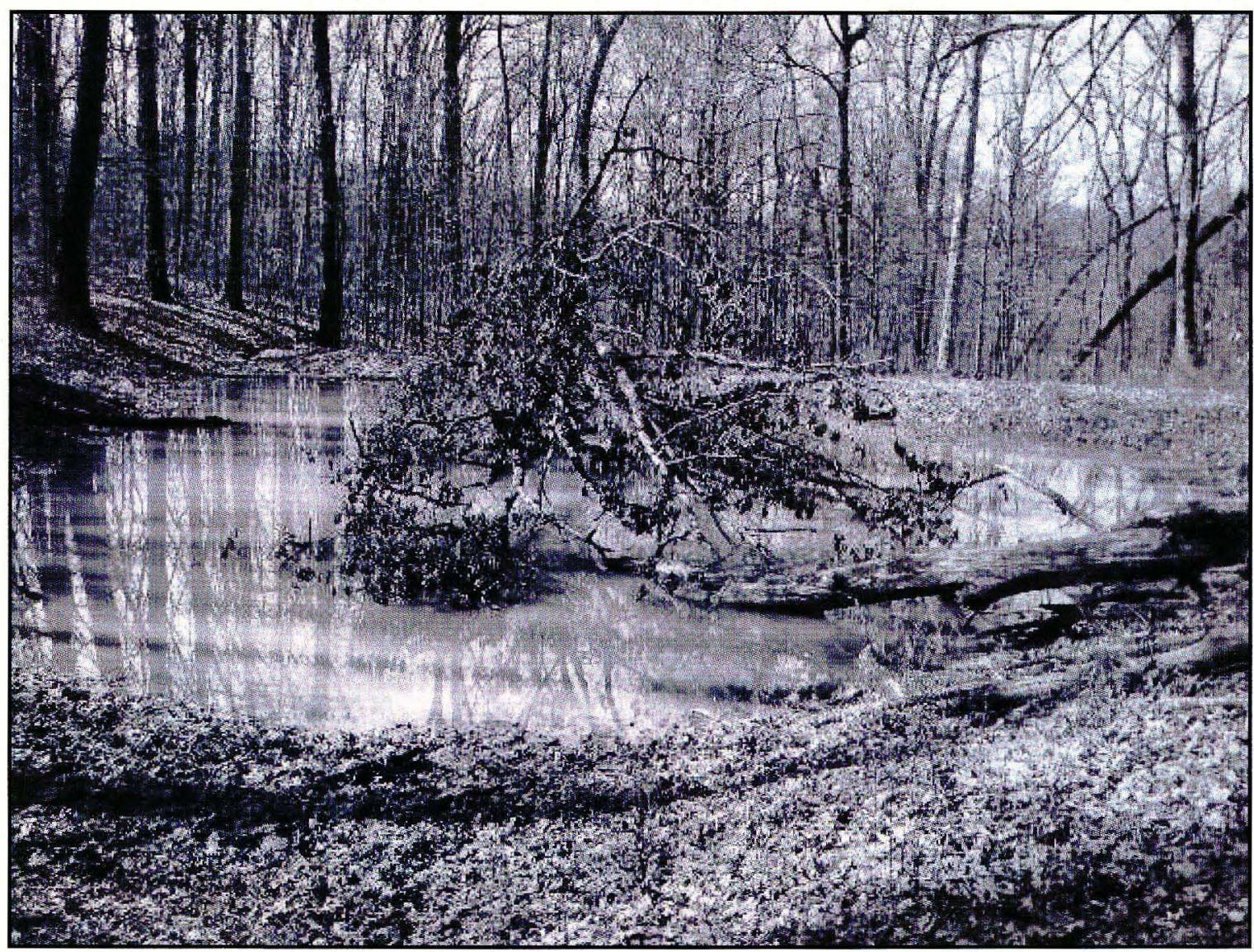




\section{Backwater ponds}

The backwater ponds were created while Wilson Creek was being redirected to its original meandering path through the field by placing earthen berms in the post-settler straight channel next to the valley wall. Since most streams run through valleys or other low areas, these ponds are at slightly lower elevations (Backwaters $1-4=152 \mathrm{~m}$; Backwaters 5 and $6=155 \mathrm{~m}$ ) than the upland ponds. Most of the ponds are long and linear, but a few are round. Because they are newly created, the mud on the bottom is not as deep as in the upland forest ponds, and all but one (Backwater 4) are wadeable with water levels below waist-deep. None of these ponds have emergent vegetation, but most have a layer of leaf litter due to high canopy cover. A large track of forest on the valley wall borders the ponds on the southeast side, and a shallow group of trees lines the opposite banks, through which a large field is present on the northwest side. 


\section{Backwater 1}

This pond is a long linear body of water with a $167.6 \mathrm{~m}$ perimeter, but it is shallow with a maximum depth of $38 \mathrm{~cm}$. It is shaded heavily by surrounding trees and gets little direct sunlight $(88.8 \%$ canopy cover $)$. Tree species around this pond in decreasing abundance include slippery elm (Ulmus rubra), black locust (Robinia pseudoacacia), eastern redbud (Cercis canadensis), sycamore, ironwood (Carpinus caroliniana), green ash, chinkapin oak, box elder (Acer negundo), hackberry (Celtis occidentalis), sugar maple, Ohio buckeye, shagbark hickory, eastern redcedar and tulip poplar.

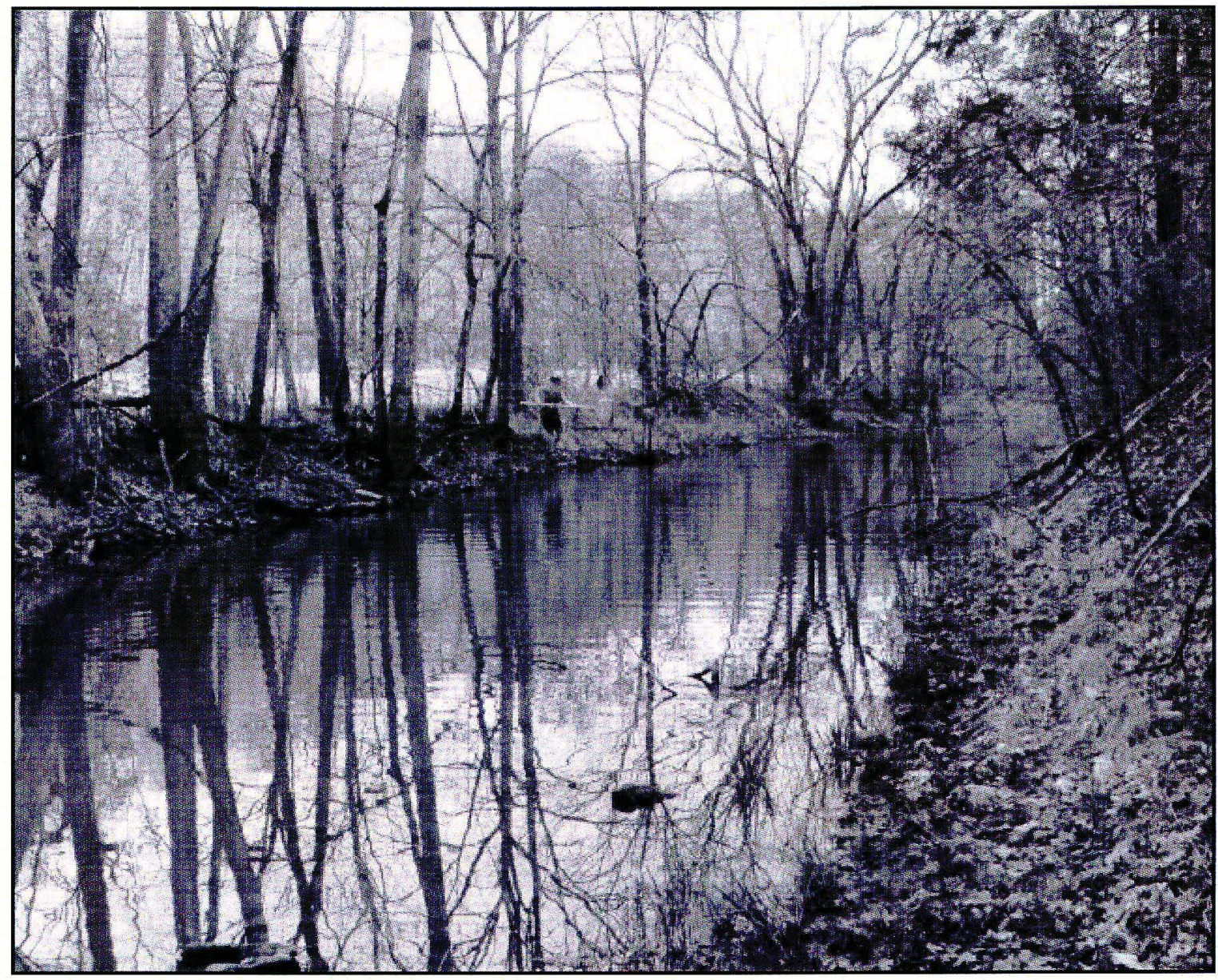




\section{Backwater 2}

Like Backwater 1, this pond is long and linear with a perimeter of $206.6 \mathrm{~m}$. It is also relatively shallow (maximum water depth $=55 \mathrm{~cm}$ ) and is heavily shaded $(88.4 \%$ canopy cover). The tree species nearby in decreasing abundance include sycamore, slippery elm, black locust, eastern redcedar, eastern redbud, sugar maple, blue ash (Fraxinus quadrangulata), Ohio buckeye, ironwood, chinkapin oak, hackberry, green ash, shagbark hickory and black walnut.

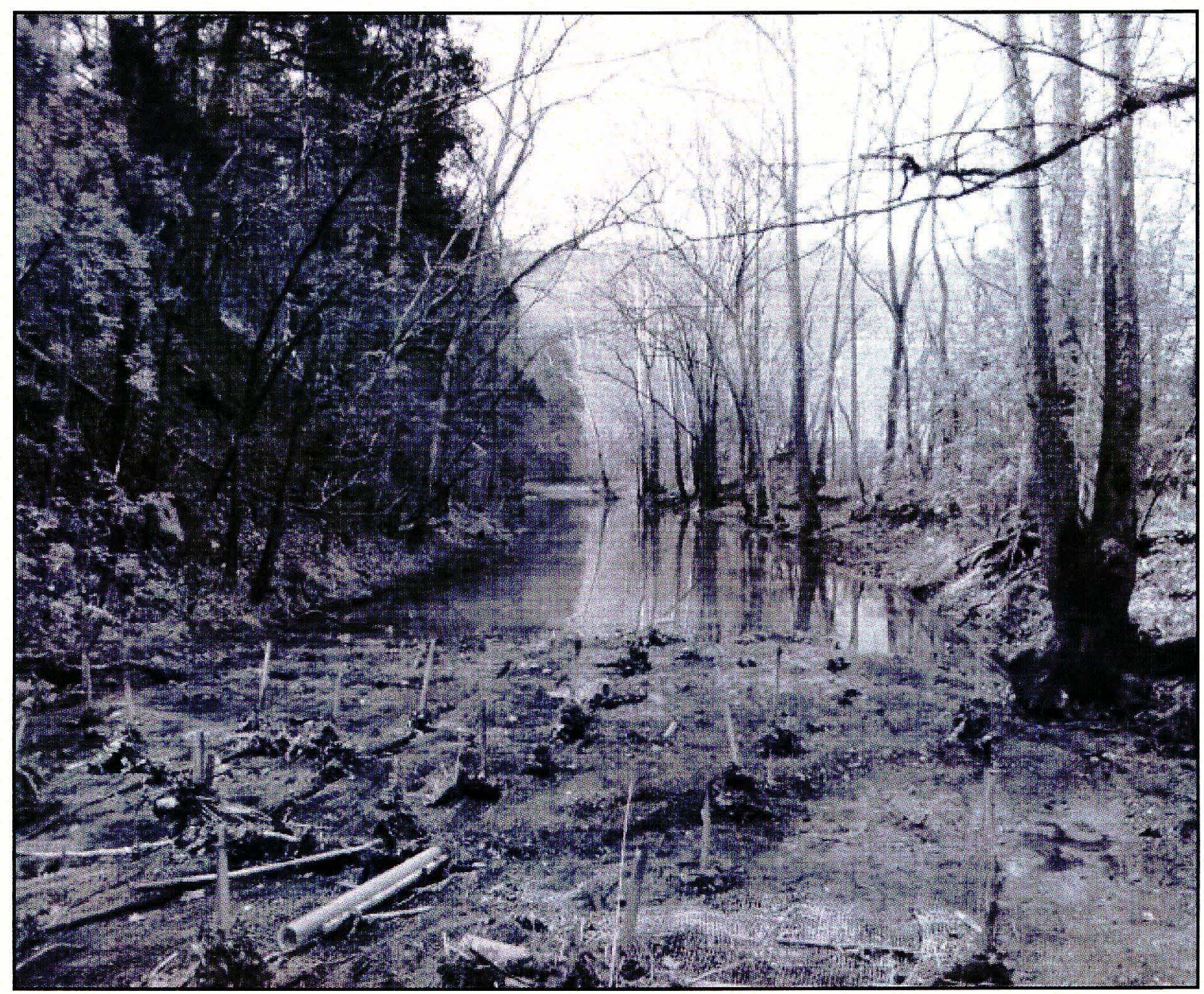




\section{Backwater 3}

This pond is the longest of all the ponds sampled (perimeter $=298.8 \mathrm{~m}$ ) but it is still fairly shallow $(65 \mathrm{~cm})$. It has the highest amount of canopy cover of any ponds studied $(93.2 \%)$. The most common tree species is sycamore followed by sugar maple, black locust, slippery elm, eastern redbud, ironwood, box elder, blue ash, chinkapin oak, tulip poplar, Ohio buckeye, eastern redcedar, pawpaw, green ash, and black walnut.

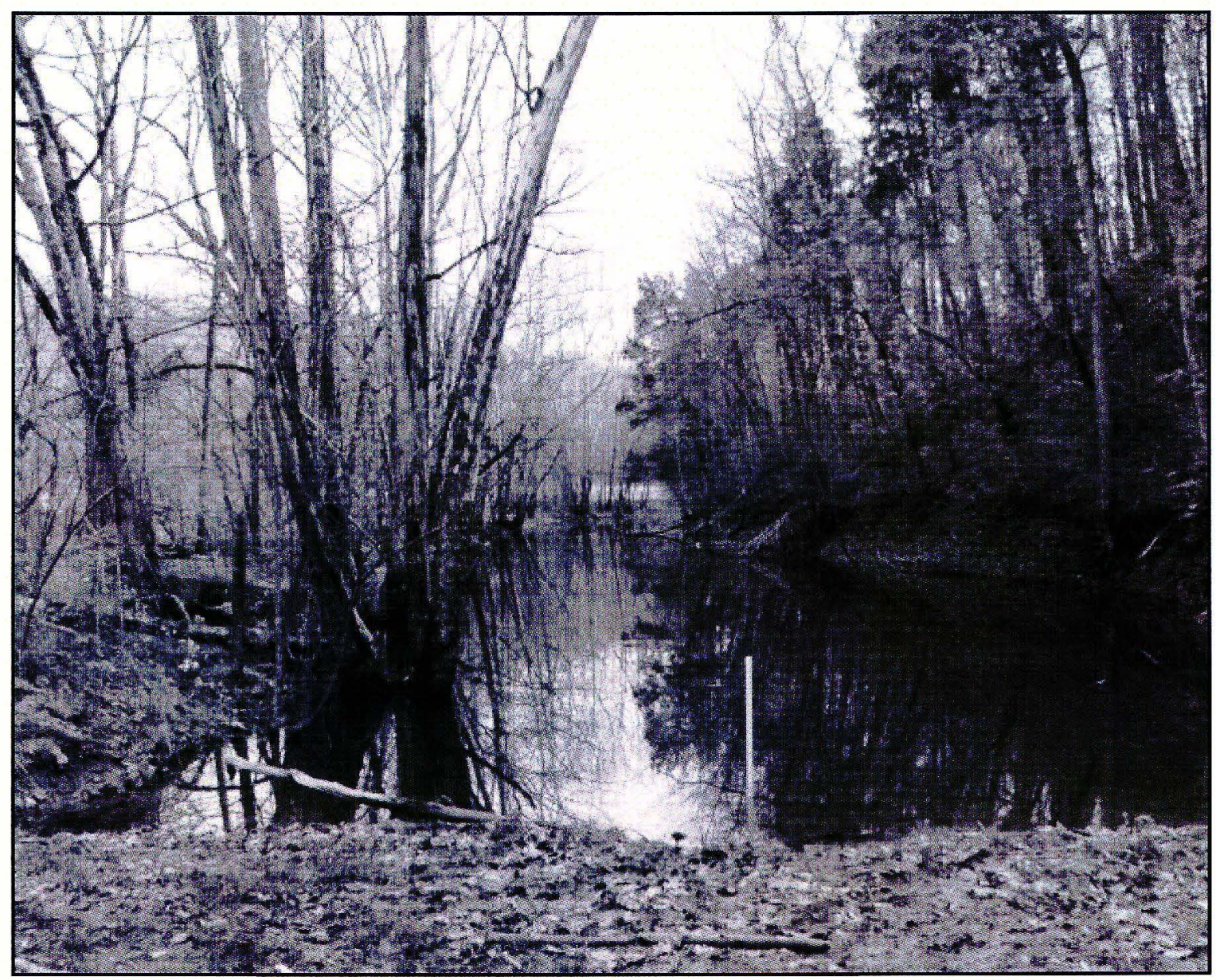




\section{Backwater 4}

This pond is much smaller (perimeter $=60 \mathrm{~m}$ ) and round in shape in contrast to the first three ponds. The mud at the bottom of the pond is quite thick, and the water level is a little deeper than the other ponds (maximum water depth $=78 \mathrm{~cm}$ ). This pond has the least amount of canopy cover of all the backwater ponds $(71.4 \%)$. The northwest side of the pond has no trees at all so the majority of canopy cover is over the southeast side. The few trees that are present in decreasing numbers are sycamore, slippery elm, box elder, Ohio buckeye, ironwood, persimmon, green ash, blue ash, and black walnut.

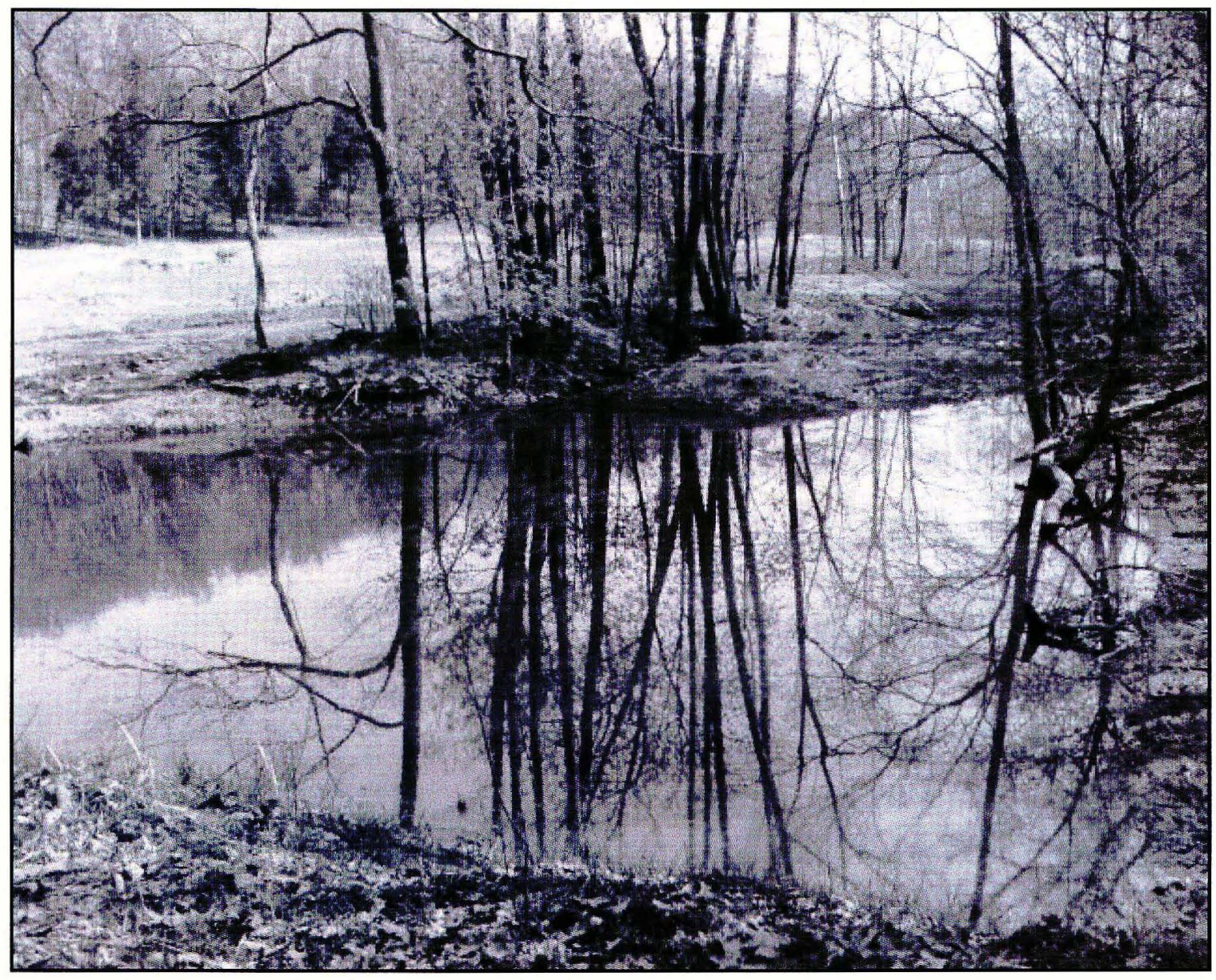




\section{Backwater 5}

This pond is not quite as long and linear as Backwaters $1-3$, but it is larger than Backwater 4 (perimeter $=100.8 \mathrm{~m}$ ). Like the first three ponds, the water is shallow enough to wade through $(38 \mathrm{~cm})$. Trees surround the edges of the pond, but the center receives copious amounts of sun (79.9\% canopy cover). The shallow water in concert with great amounts of sunlight allows aquatic vegetation to fill the majority of the pond. Tree species in decreasing numbers are slippery elm, green ash, ironwood, eastern redcedar, sugar maple, sycamore, box elder, eastern redbud, persimmon, black walnut, and chinkapin oak.

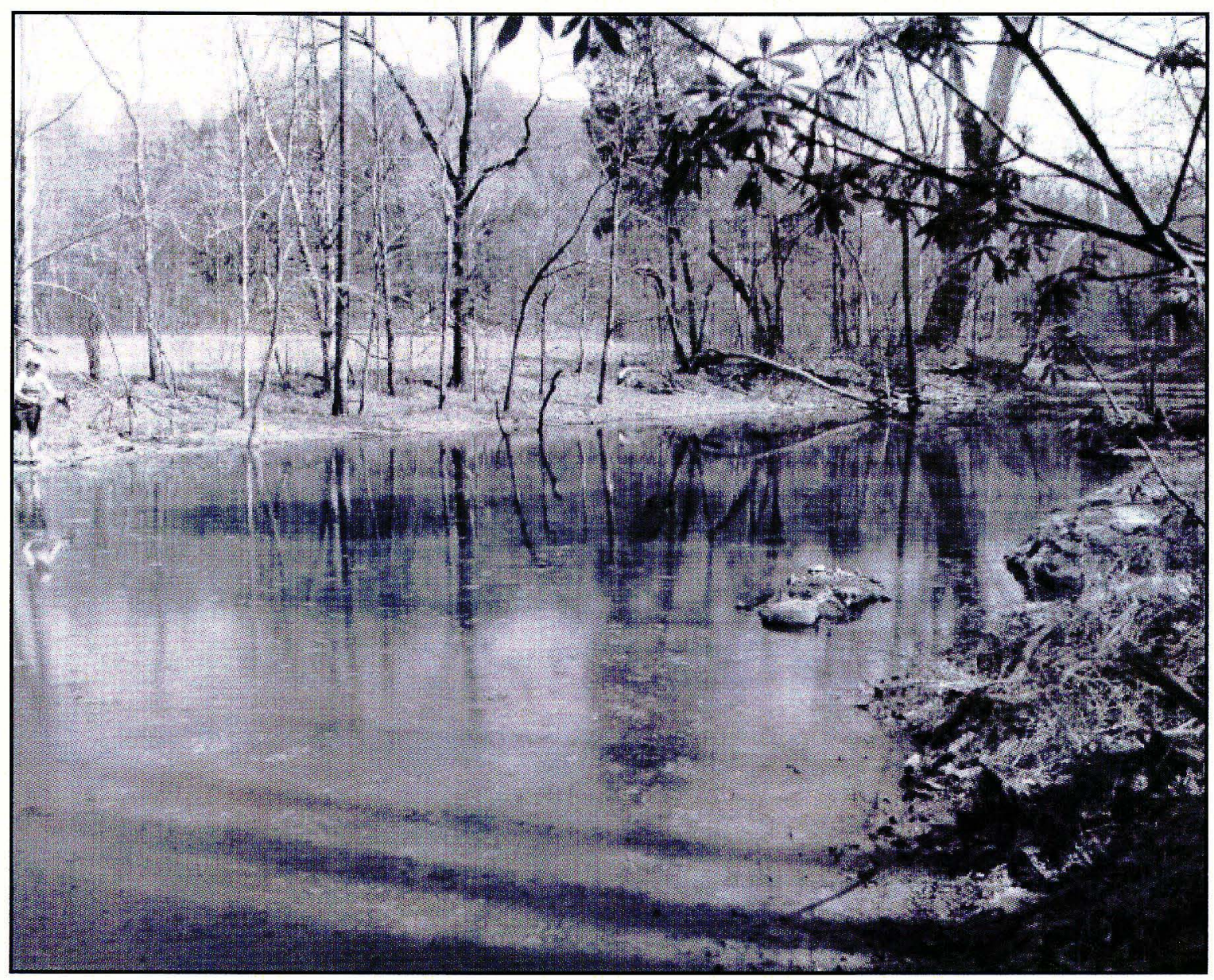




\section{Backwater 6}

This is a very small pond (perimeter $=33.9 \mathrm{~m}$, maximum water depth $=37 \mathrm{~cm}$ ) with $84.4 \%$ canopy cover. There are no trees on the north side, but the tree limbs from the south side cover the entire pond. The few trees present are ironwood, sugar maple, Ohio buckeye, black walnut, and slippery elm.

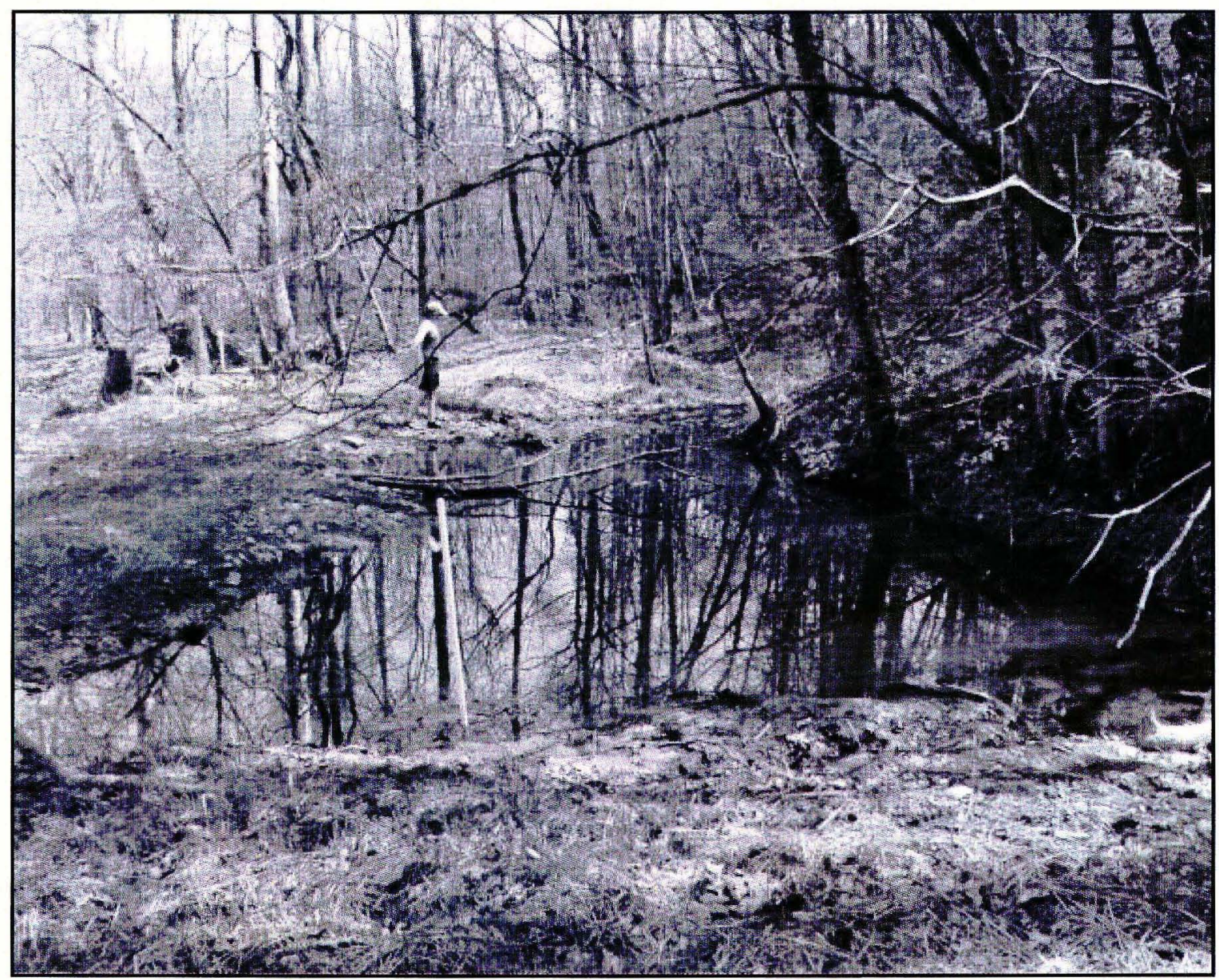




\section{Pools}

Thirteen ephemeral and two semi-permanent pools (Figure 8) near the backwater ponds scattered along the floodplain of the restored Wilson Creek were also observed for species richness, but no physical or chemical characteristics were systematically measured. All pools had shallow water (approx. $<20 \mathrm{~cm}$ ) and thin, fine mud substrates. Because the pools are located between the forest edge and the creek in an open field or are on the non-forested side of the creek, most pools have very low canopy cover (if any at all), thereby receiving partial to full sunlight. Occasional temperature readings were similar to or higher than the water temperatures of the backwater ponds. The shallow water, ample solar exposure, and reduced leaf litter input creates different aquatic habitat than the backwater ponds.

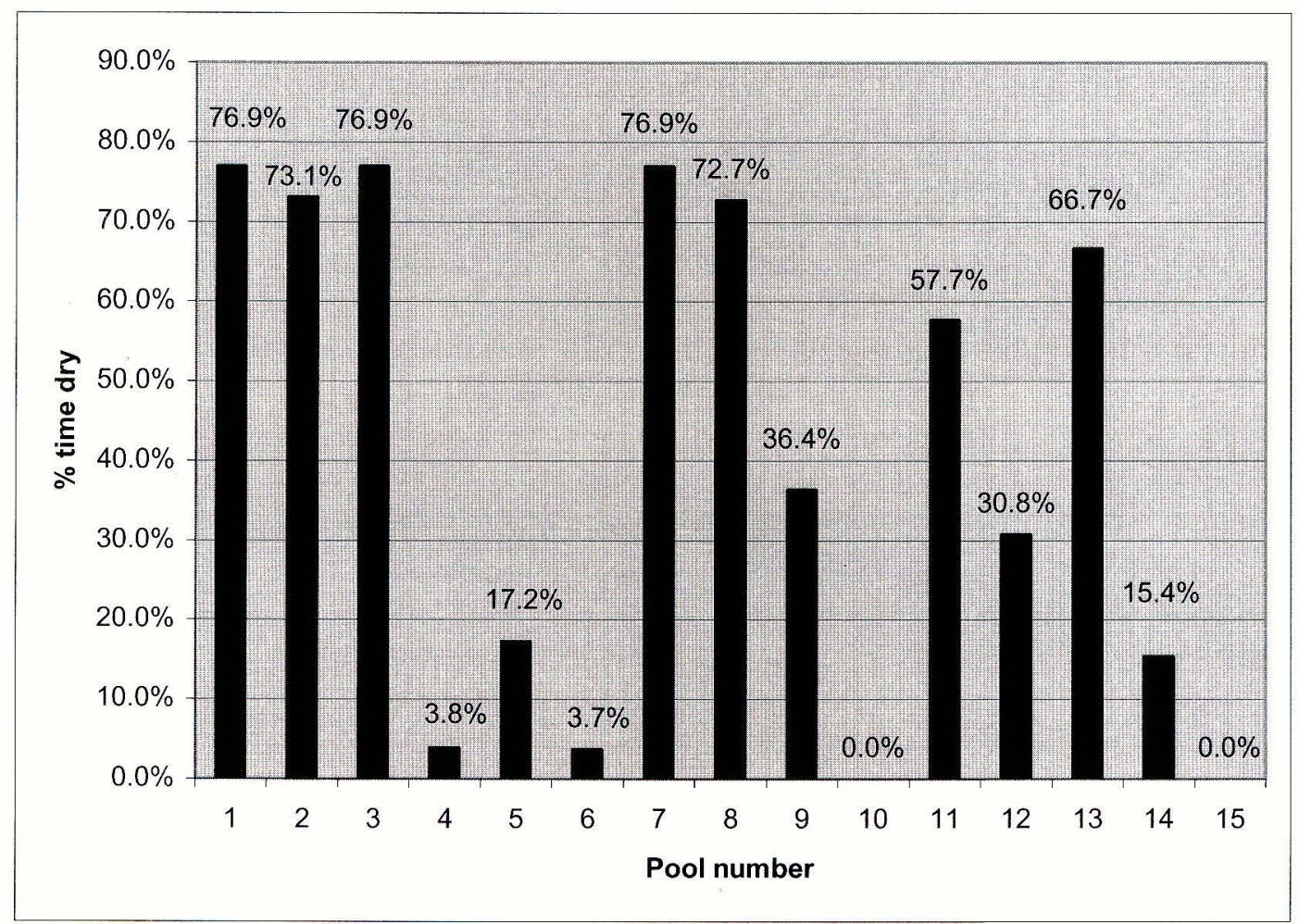

Figure 8. Percent of time that the ephemeral and semi-permanent pools surveyed were dry over two years of sampling. Pool \#10 and Pool \#15 never dried completely, but the other pools were ephemeral. 


\section{Amphibian sampling}

Sampling for amphibians took place weekly from February through July in 2005 and 2006 by a combination of visual surveys and dip-netting with approval by the Institutional Animal Care and Use Committee (IACUC; Appendix 1). This sampling period encompasses known amphibian breeding periods when adults, eggs, and/or larvae would be encountered in ponds at Bernheim Forest. Upon arrival at each pond, a field assistant and I conducted a visual survey around the perimeter to identify egg masses and adult amphibians. To assess amphibian larval species richness and abundance, we took sweeps with the D-shaped dip net $($ mesh size $=0.5 \mathrm{~cm}$, net frame $=38 \times 38 \mathrm{~cm}$, handle $=$ $1.5 \mathrm{~m}$ long) at least every $5 \mathrm{~m}$ around the perimeter of each pond in order to consider them independent samples (Shaffer et al. 1994). The size of the pond determined the number of sweeps taken, so this number varied from pond to pond. Shaffer et al. (1994) suggest that if no new amphibian larvae are caught after 10 sweeps, it is safe to assume that the population has been sampled sufficiently. In this study, most amphibian species were sampled in the first few sweeps of a given pond. We sampled the entire perimeter of some ponds with fewer than 10 sweeps, but if the perimeter was larger, Shaffer's "10 sweep rule" was generally employed.

We monitored the small pools scattered in the field near the backwater ponds along the new path of Wilson Creek for species richness in both years of the study, but we did not collect consistent data on abundance. Visual surveys were employed for the majority of the data collected, but a few dip-net sweeps were taken if the water was deep or murky. 
Amphibians were identified to species, except larvae of Ambystoma jeffersonianum (Jefferson's salamander) and A. maculatum (spotted salamander), which were recorded as Ambystomid. In 2005, no voucher specimens were collected so all animals were returned to the pond immediately after identification; however, some photographs were taken. Larval identification was conducted in the field using a combination of several published and online sources (Appendix 2) and personal communication with Kentucky state herpetologist John MacGregor (Kentucky Department of Fish and Wildlife Resources, Frankfort, Kentucky) and Mark Gumbert (Copperhead Environmental Consulting, Inc., Paint Lick, Kentucky). Photographs of some larvae were analyzed later for positive identification. In 2006, I used the same field identification, but some tadpoles were collected for positive identification and as voucher specimens. Tadpoles were anesthetized in MS222, fixed in 70\% ethyl alcohol and stored

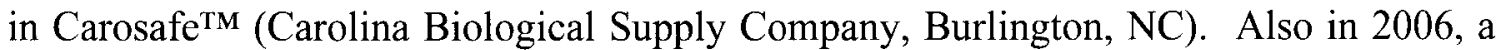
photographic library was created of egg masses, juveniles and adult amphibians encountered during the survey. Information about species present on the property was obtained through the volunteer Frogloggers organization that conducts call surveys twice a year at twelve sites at Bernheim Forest.

\section{Water Chemistry}

In order to measure water chemistry parameters, I took water samples from all ponds once in the spring and once in the summer in both years. I collected water in amber Nalgene ${ }^{\odot}$ bottles and kept the bottles in a cooler on ice for transport to the lab. Field values for dissolved oxygen (DO mg/L), percent dissolved oxygen $(\% \mathrm{DO}), \mathrm{pH}$ and 
conductivity $(\mu \mathrm{S} / \mathrm{cm})$ were taken with a Hydrolab MiniSonde ${ }^{\mathcal{O}} 4$. In the lab, water samples were separated and prepared for analysis. In 2005, water was lab-tested using standard methods (APHA 1998) for nitrate+nitrite $\left(\mathrm{NO}_{3}+\mathrm{NO}_{2} \mu \mathrm{g} / \mathrm{L}\right.$ ), ammonia $\left(\mathrm{NH}_{4}\right.$ $\mu \mathrm{g} / \mathrm{L}$ ), total nitrogen $(\mathrm{TN} \mu \mathrm{g} / \mathrm{L}$ ), soluble reactive phosphorous (SRP $\mu \mathrm{g} / \mathrm{L}$ ), total phosphorous ( $\mathrm{TP} \mu \mathrm{g} / \mathrm{L}$ ), silica ( $\mathrm{Si} \mathrm{mg/L),} \mathrm{chloride}(\mathrm{Cl} \mathrm{mg} / \mathrm{L}$ ), dissolved organic carbon (DOC mg/L), and turbidity (NTU). In 2006, both water samples collected were tested for all the compounds from 2005 except total nitrogen. This factor was not significantly different between any ponds in 2005, so it was not sampled for in 2006 .

StowAway ${ }^{\circledR}$ TidBit $(\AA)$ underwater temperature data loggers were placed in the ponds to record water temperature every 30 minutes through, and slightly beyond, the main breeding season of amphibians in this area (February - September).

\section{Statistical Analysis}

I conducted principle component analysis (PCA) using CANOCO for Windows v.4.53 (ter Braak and Šmilaurer 1998) to determine what species and physical and chemical parameters were correlated with which pond. I used multivariate analysis of variance (MANOVA) to determine differences between backwater ponds and upland forest ponds in terms of their physical characteristics. Univariate factors were then compared for differences between pond types in particular characteristics. Data for water chemistry parameters were not normally distributed, so I used the Mann-Whitney $U$ test to determine differences between pond types.

I calculated mean species richness by recording the number of species observed at each pond and averaging the values for backwater ponds and upland forest ponds. A 
species was considered present if any life stage was observed, i.e., egg, larvae or adult. I calculated abundance using mean capture rate. For each pond I calculated capture rate by using the number of larval amphibians caught per dip-net sweep (capture rate $=$ total \# larvae caught in pond / total \# sweeps taken in that pond). Species richness data was normally distributed and because parametric tests have more power, I used $t$-tests to determine differences between pond types over both years and differences among pond types between years. Capture rate data was not normally distributed, so I used nonparametric tests to compare ponds. Again, I used the Mann-Whitney $U$ test to compare the two pond types in terms of species richness and capture rate, and I used the Wilcoxon paired-sample test to compare capture rates in the backwater ponds between two years.

I used Shannon's diversity index to determine the species diversity of each pond sampled. This index was used over Simpson's diversity index because Shannon's is more sensitive to rare species, giving less weight to more common species. Because larval amphibians were the only life stage to be consistently encountered in every pond sampled, diversity indices were calculated only using tadpoles and Ambystomid larvae. Abundances for egg masses or adult amphibians were not used in this analysis. In some cases, egg masses were observed in a pond and the larvae were not collected in the dipnet so these species were not included in the calculation. However, because this was true for all ponds, the calculation using only larval amphibians is valid.

In order to correlate species richness and abundance with chemical characters, I performed linear regressions on those factors with strong associations to particular ponds from the PCA. These environmental factors were used to help explain differences in amphibian assemblage between the backwater and upland forest ponds. All physical 
characters were used in a backward stepwise regression against species richness and abundance to determine correlations between environmental and biotic factors. All tests performed were considered significant when $p<0.05$. 


\section{RESULTS}

\section{Physical parameters and water chemistry}

Results from the Principle Component Analysis (PCA) separated ponds based on abiotic factors (Figure 9) and the first two axes explained $78.9 \%$ of the variance (Table 2). These parameters separate the upland forest ponds on the left side of the $y$-axis correlated with deeper maximum water depth, greater distance to the forest edge, and higher elevation indicated by long arrows pointing toward the upland ponds. The backwater ponds are on the right side of the y-axis correlated with greater perimeter size, higher conductivity levels and higher $\mathrm{pH}$ values, again indicated by long arrows. $\mathrm{pH}$ and conductivity had the highest loading scores (Table 2) and were therefore used later in linear regression tests to correlate with species richness and abundance of amphibian larvae in backwater ponds and upland forest ponds.

When analyzed together, the physical characteristics (perimeter size, maximum water depth, distance to the forest edge, and elevation) of backwater ponds $(n=6)$ differed significantly from upland ponds $\left(\mathrm{n}=5\right.$; MANOVA; $\left.\mathrm{F}_{4,6}=84.244, p<0.001\right)$. However, univariate tests revealed that perimeter and maximum water depth were not significantly different between pond types, but the distance to the forest edge and the elevation were (Table 3). Even though perimeter and maximum water depth were not 
significantly different, the backwater ponds on average had a larger circumference by $82.7 \mathrm{~m}$ and were shallower by $39.9 \mathrm{~cm}$ (Figure 10 and 11, respectively). Backwater ponds were significantly closer to the edge by $18.9 \mathrm{~m}$, and were significantly lower in elevation by $78.9 \mathrm{~m}$ (Figure 12 and 13, respectively).

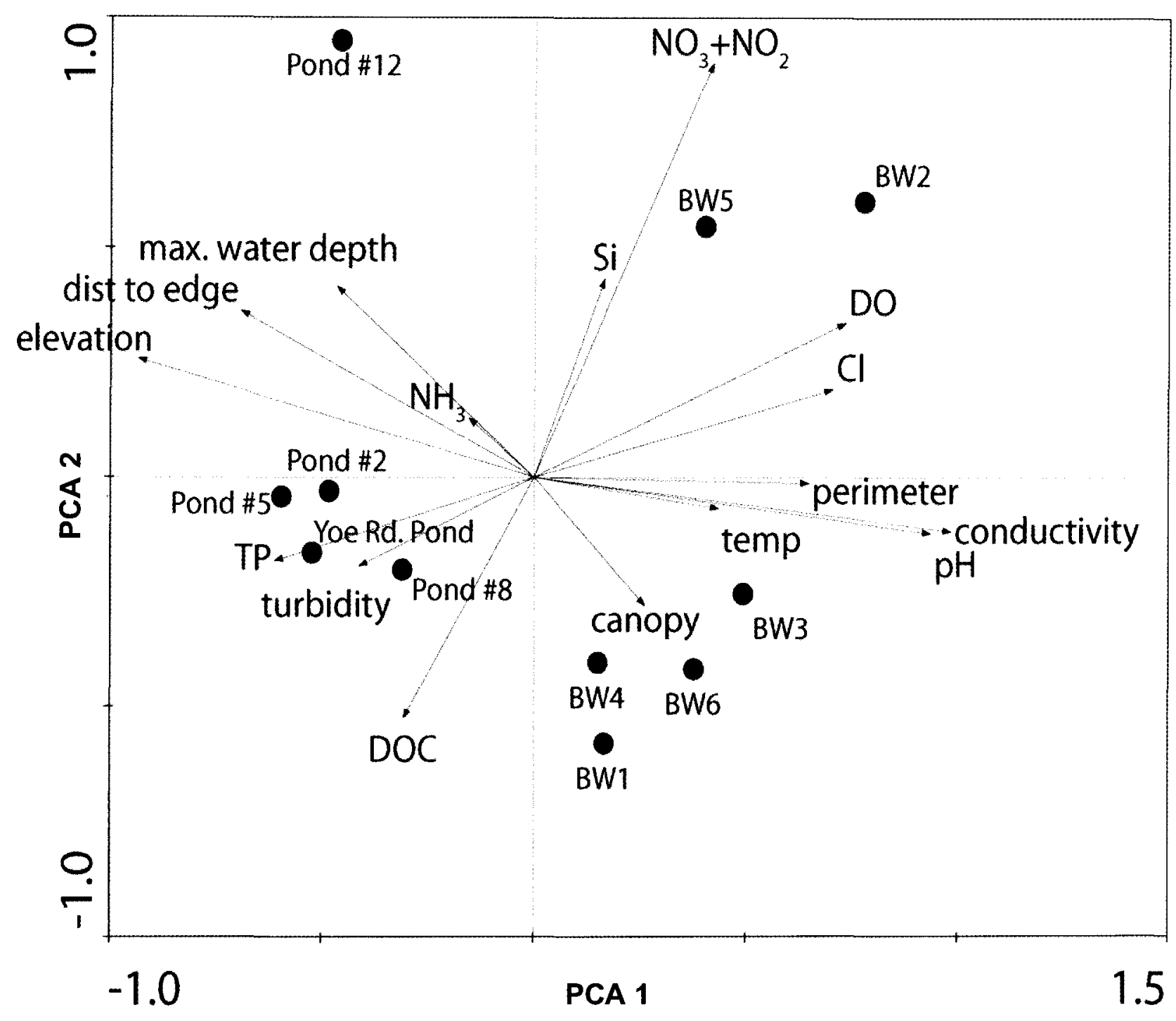

Figure 9. Principle component analysis (PCA) ordination depicting relationships among pond types and abiotic variables. The importance of an abiotic variable in grouping ponds together is represented by the length and direction of the arrows. BW = backwater pond. See Table 2 for explanation of other terms. 
Table 2. Eigenvalues for the four axes (AX $1-4)$ of the PCA ordination used to group ponds in terms of environmental factors and the scores of those physical and chemical variables.

\begin{tabular}{|c|c|c|c|c|c|}
\hline \multirow{2}{*}{ Abbreviation } & \multirow{2}{*}{$\begin{array}{l}\text { Environmental } \\
\text { factor }\end{array}$} & \multirow{2}{*}{$\begin{array}{r}\text { AX1 } \\
0.6204 \\
\end{array}$} & \multirow{2}{*}{$\frac{\mathrm{AX2}}{0.1684}$} & \multirow{2}{*}{$\frac{\mathrm{AX3}}{0.1382}$} & \multirow{2}{*}{$\frac{\mathrm{AX} 4}{0.0428}$} \\
\hline & & & & & \\
\hline $\mathrm{NO}_{3}+\mathrm{NO}_{2}$ & nitrate+nitrite $(\mu \mathrm{g} / \mathrm{L})$ & 0.4213 & 0.9027 & -0.0445 & -0.0567 \\
\hline $\mathrm{NH}_{3}$ & $\operatorname{ammonia}(\mu \mathrm{g} / \mathrm{L})$ & -0.1547 & 0.1298 & 0.9473 & 0.2449 \\
\hline TP & total phosphorus $(\mu \mathrm{g} / \mathrm{L})$ & -0.6127 & -0.1822 & 0.2687 & -0.0557 \\
\hline $\mathrm{Cl}$ & chlorine (mg/L) & 0.7057 & 0.1908 & -0.2370 & -0.0086 \\
\hline DOC & dissolved organic carbon $(\mathrm{mg} / \mathrm{L})$ & -0.3071 & -0.5263 & 0.2217 & -0.0362 \\
\hline $\mathrm{pH}$ & $\mathrm{pH}$ & 0.9370 & -0.1234 & -0.0852 & -0.0563 \\
\hline conductivity & conductivity $(\mu \mathrm{g} / \mathrm{L})$ & 0.9851 & -0.1188 & 0.1172 & -0.0370 \\
\hline temp & temperature $\left({ }^{\circ} \mathrm{C}\right)$ & 0.4371 & -0.0682 & 0.1102 & -0.2588 \\
\hline DO & dissolved oxygen $(\mathrm{mg} / \mathrm{L})$ & 0.7344 & 0.3352 & -0.3046 & 0.1808 \\
\hline turbidity & turbidity (NTU) & -0.4136 & -0.1940 & 0.4557 & 0.2932 \\
\hline $\mathrm{Si}$ & silica $(\mathrm{mg} / \mathrm{L})$ & 0.1652 & 0.4338 & -0.2511 & -0.2697 \\
\hline canopy & canopy cover $(\%)$ & 0.2631 & -0.2798 & -0.3146 & 0.2851 \\
\hline perimeter & perimeter of pond $(\mathrm{m})$ & 0.6494 & -0.0142 & -0.4913 & 0.5723 \\
\hline max.water depth & maximum water depth $(\mathrm{cm})$ & -0.4668 & 0.4163 & 0.1324 & 0.3632 \\
\hline dist to edge & distance to forest edge (m) & -0.6934 & 0.3623 & 0.1201 & 0.5471 \\
\hline elevation & elevation (m) & -0.9361 & 0.2582 & 0.0501 & 0.1419 \\
\hline
\end{tabular}

Table 3. Results of univariate analysis as part of a MANOVA test to determine differences in physical characteristics of backwater ponds $(n=6)$ vs. upland forest ponds $(n=5)$.

\begin{tabular}{|c|c|c|c|c|}
\hline nivariate analysis & $\begin{array}{l}\text { Perimeter } \\
\text { (m) }\end{array}$ & $\begin{array}{l}\text { Max. water } \\
\text { depth }(\mathrm{cm})\end{array}$ & $\begin{array}{c}\text { Distance } \\
\text { to edge } \\
\text { (m) }\end{array}$ & $\begin{array}{l}\text { Elevation } \\
\text { (m) }\end{array}$ \\
\hline $\mathrm{F}_{9,10}$ & 3.839 & 4.412 & 22.522 & 384.341 \\
\hline$p$-value & 0.082 & 0.072 & 0.001 & $<0.001$ \\
\hline
\end{tabular}




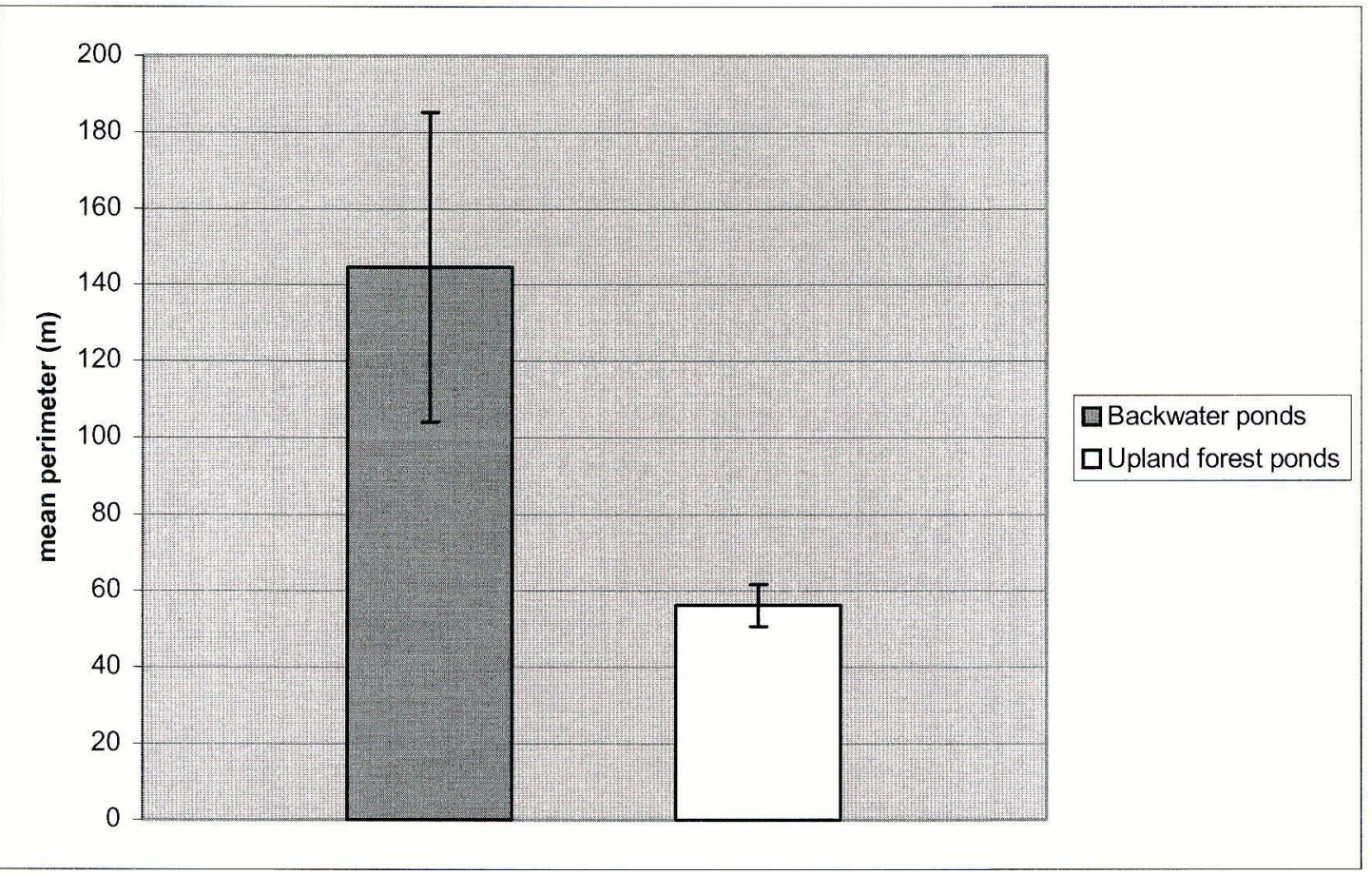

Figure 10. Perimeter size averaged for each pond type sampled at Bernheim Arboretum and Research Forest, Clermont, Kentucky. The difference is not significant.

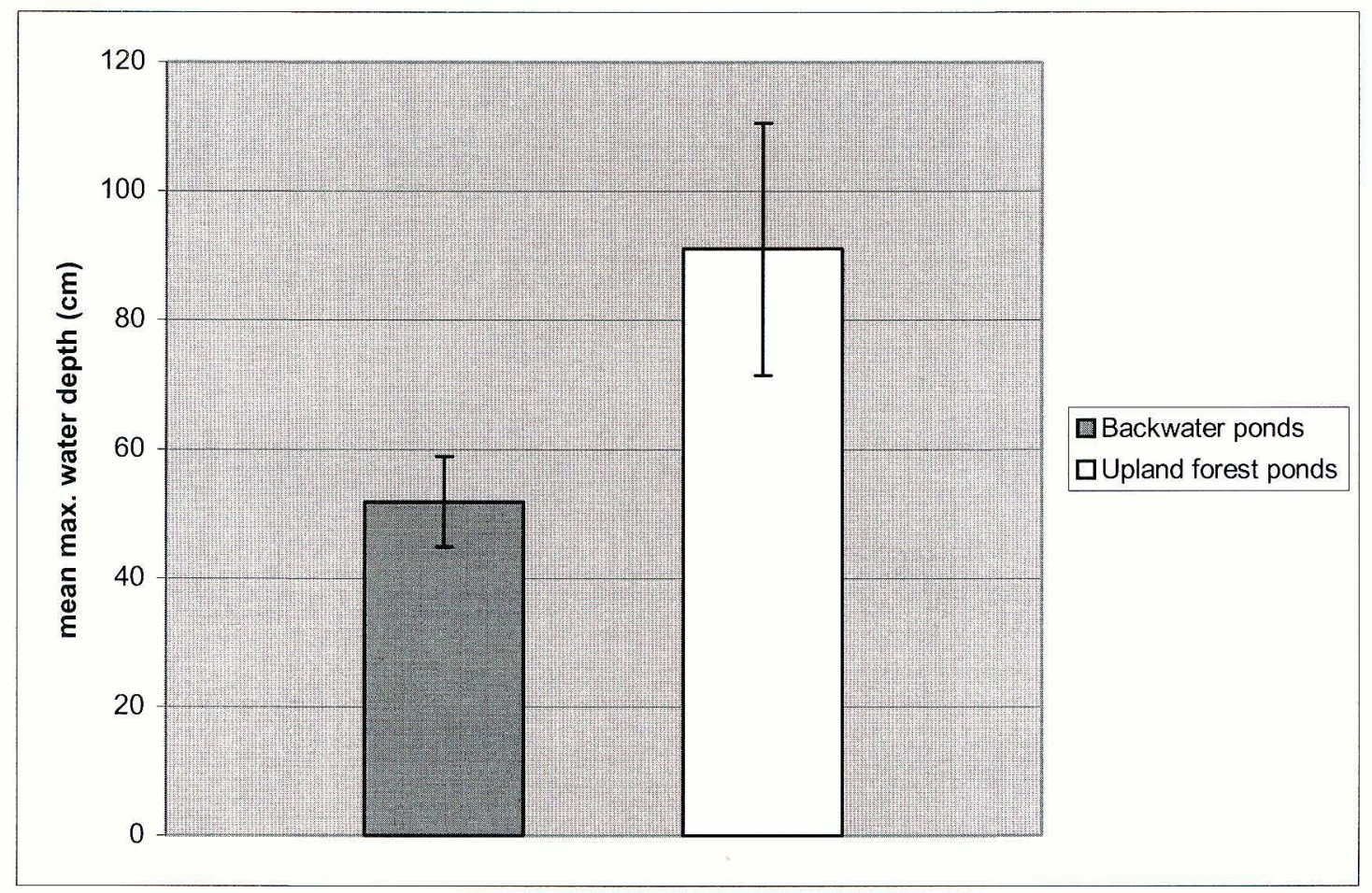

Figure 11. Maximum water depth averaged for each pond type sampled at Bernheim Arboretum and Research Forest, Clermont, Kentucky. The difference is not significant. 


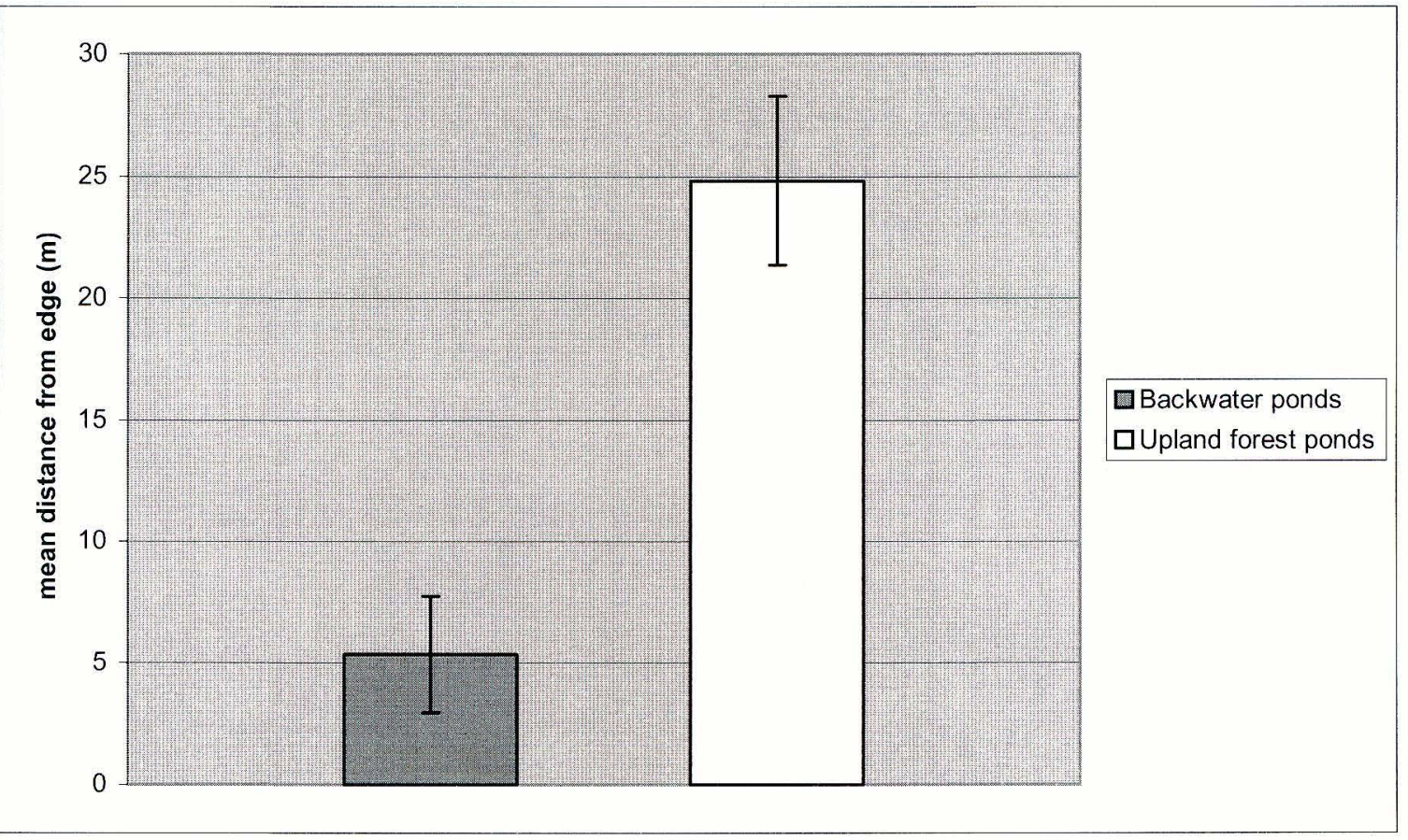

Figure 12. Distance from pond to forest edge averaged for each pond type sampled at Bernheim Arboretum and Research Forest, Clermont, Kentucky. The difference is significant.

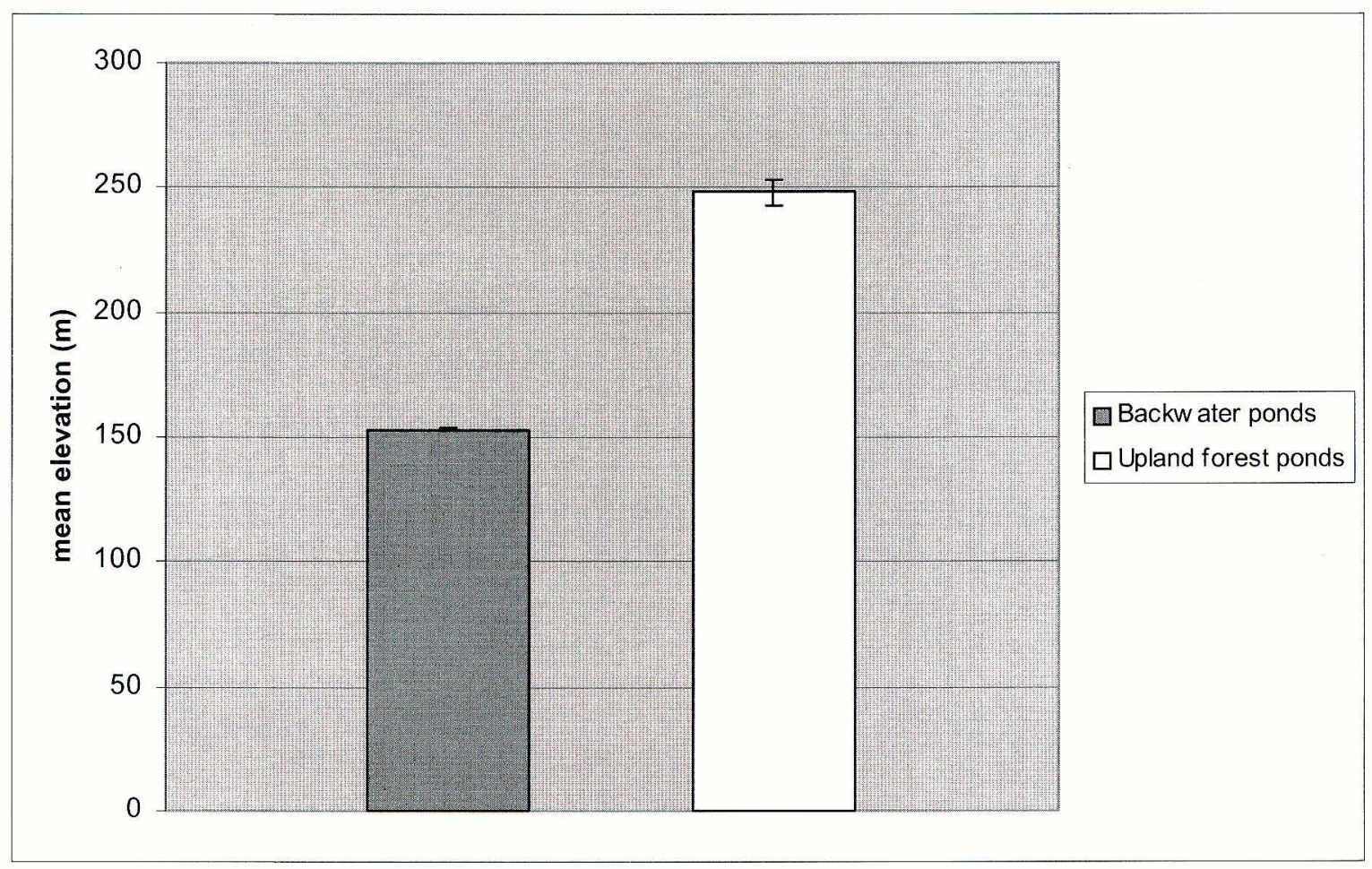

Figure 13. Elevation averaged for each pond type sampled at Bernheim Arboretum and Research Forest, Clermont, Kentucky. The difference is significant. 
Because $\mathrm{pH}$ and conductivity were important factors in the PCA ordination, I compared levels of these factors between pond types. $\mathrm{pH}$ and conductivity were significantly higher in backwater ponds $(\mathrm{n}=6)$ than in the upland forest ponds $(\mathrm{n}=5$; Mann-Whitney $U=30, \mathrm{df}=6, p=0.004)$. Backwater ponds had higher average $\mathrm{pH}$ readings by $\mathrm{pH} 1.47$ (Figure 14) and higher conductivity readings by $354.9 \mathrm{ug} / \mathrm{L}$ (Figure $15)$.

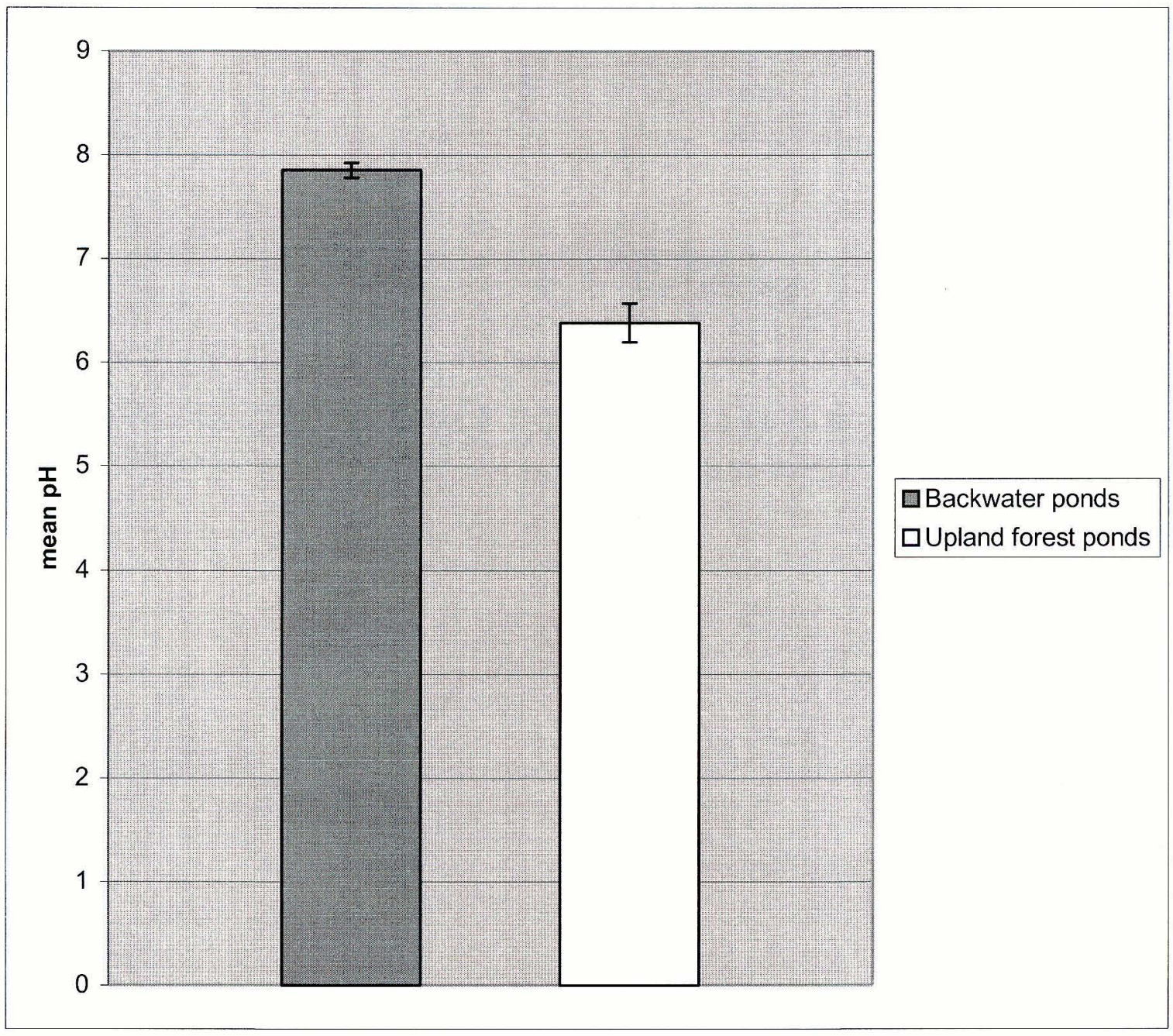

Figure 14. Mean $\mathrm{pH}$ levels of two pond types sampled at Bernheim Arboretum and Research Forest, Clermont, Kentucky. 


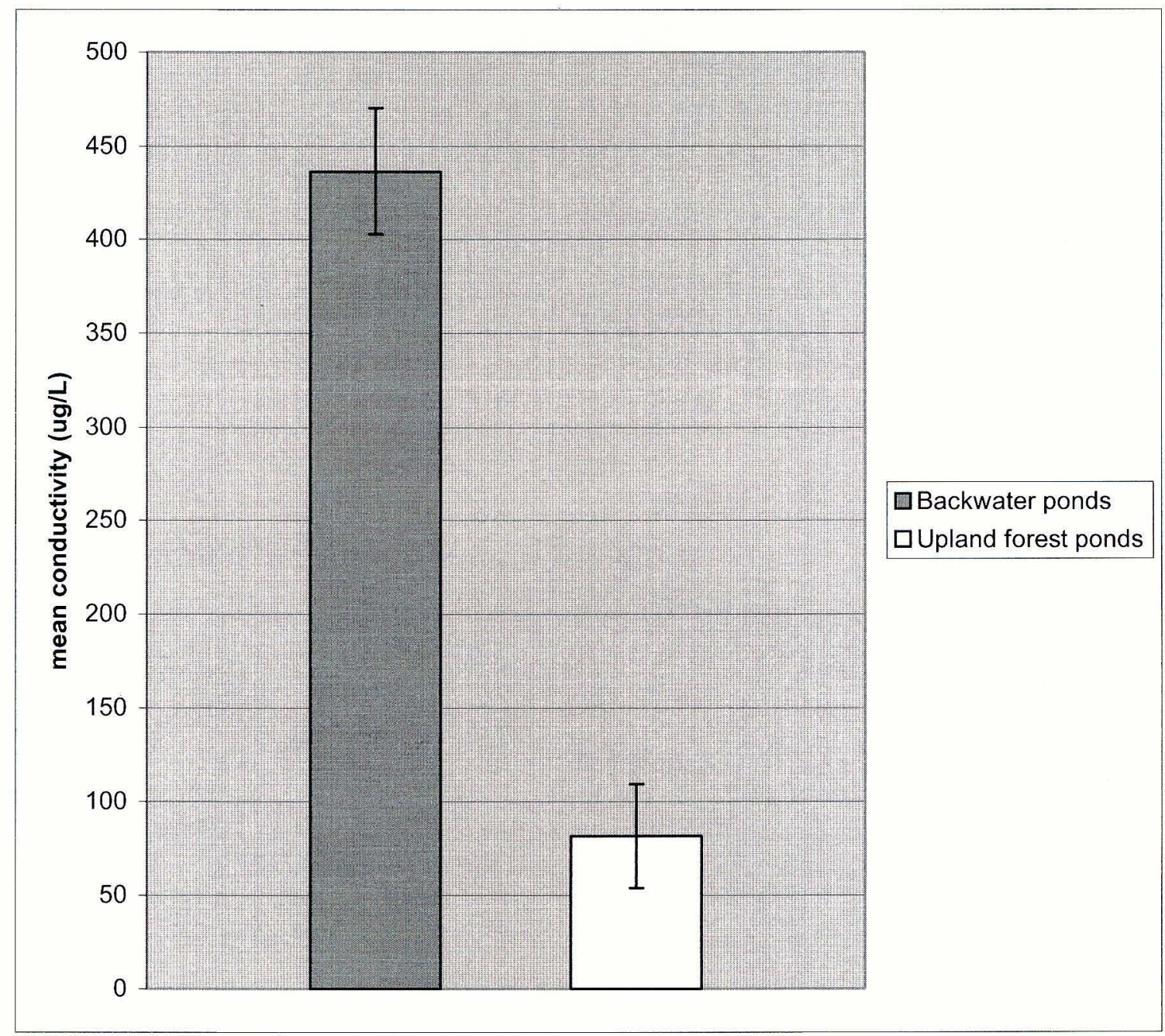

Figure 15. Mean conductivity levels of two pond types sampled at Bernheim Arboretum and Research Forest, Clermont, Kentucky.

\section{Amphibian composition}

Fourteen amphibian species (10 anurans and 4 species of salamanders) were recorded from eleven ponds at Bernheim Forest in 2005 and 2006, but not all species were found in all ponds. One hypothesis for this study was that upland forest ponds would have higher species richness and higher abundance than the new backwater ponds. Species richness was significantly higher in upland forest ponds $(n=5)$ than in backwater 
ponds ( $\mathrm{n}=6$; two-tailed $t$-test; $t=-2.973, \mathrm{df}=9, p=0.016$ ), and all of the forest ponds had more species than any of the backwater ponds in both years, except Pond \#12 (Figure 16). Abundance was also significantly higher in upland forest ponds (Mann-Whitney $U$ $=30.0, \mathrm{df}=6, p=0.004)$, thereby supporting his hypothesis.

A second hypothesis was that species richness and abundance would increase in the backwater ponds in the second year of the study. Species richness was significantly higher in the backwater ponds $(\mathrm{n}=6)$ in 2006 from 2005 (two-tailed $t$-test; $t=-3.379$, df $\doteq 5, p=0.02$ ), and the average number of species increased from 4.3 to 6.3 species per pond. However, abundance did not increase in the backwater ponds from 2005 to 2006 (Wilcoxon paired-sample test; $t=6.0, p=0.813$ ). Although there was no significant difference in abundance between years in the backwater ponds, abundance did increase slightly from 2005 to 2006 (Figure 17).

Each of the six newly created backwater ponds sampled contained at least one new species in 2006 that was not present in 2005 (Table 4), including strongly philopatric species such as Notophthalmus viridescens (eastern red-spotted newt; Gill 1978) and $A$. maculatum (Vasconcelos and Calhoun 2004). Backwater 1 had A. maculatum egg masses in $2006(n=54)$, but very few larvae were netted $(n=2)$. Also, many of the embryos turned white with algae growing on them and did not hatch. This phenomenon was observed sparingly in other ponds, but seemed to be severe in Backwater 1. Two egg masses of A. jeffersonianum were documented in Backwater 2 on one day in 2006. I did not observe these egg masses the following week, and because Ambystomid egg masses remain in ponds for several weeks, I assume that these did not hatch. Therefore, the egg masses of this species that were laid did not produce viable offspring. Another species 


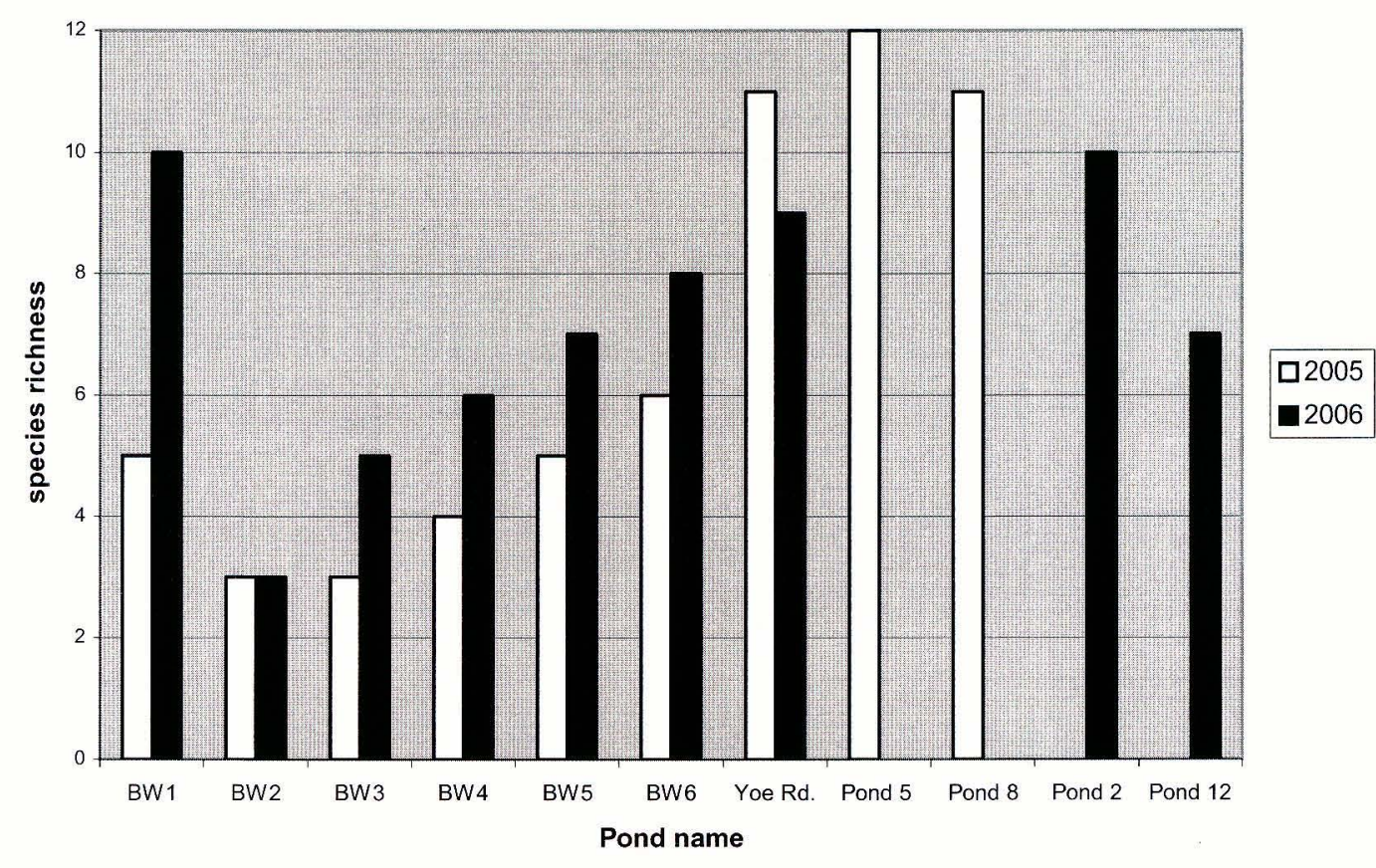

Figure 16. Number of species documented in each of the ponds sampled in 2005 and 2006 at Bernheim Arboretum and Research Forest, Clermont, Kentucky. BW= backwater pond.

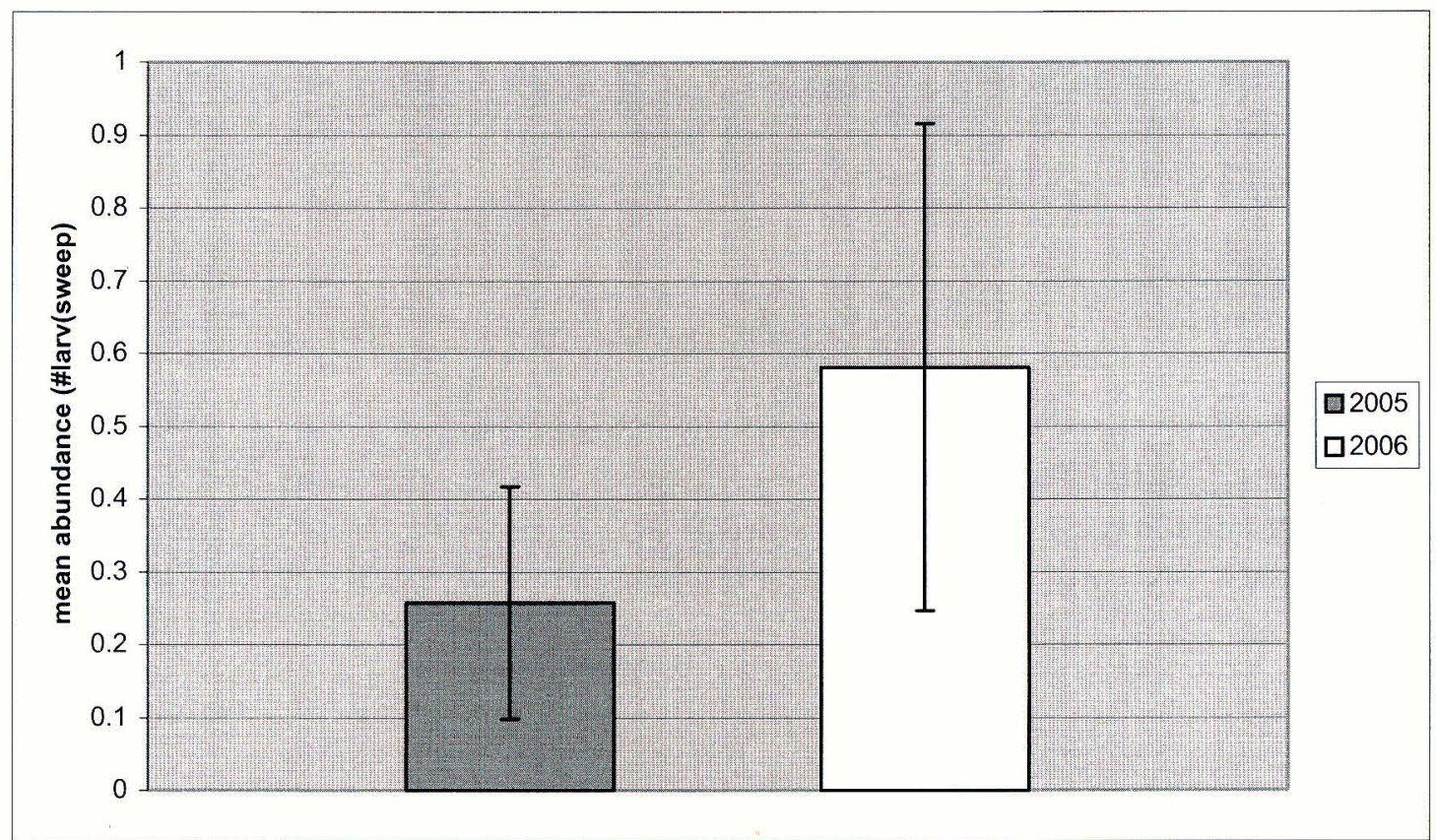

Figure 17. Average abundance (mean capture rate) of the backwater ponds in two amphibian breeding seasons at Bernheim Arboretum and Research Forest, Clermont, Kentucky. 
only found in one backwater pond was Rana sylvatica (wood frog). Only one $R$. sylvatica egg mass was laid in Backwater 6 in late March 2006, and it was partially hatched the following week. However, no tadpoles were dip-netted after the egg mass hatched. This pond was very small in circumference and depth, and any tadpoles of this species would have been caught in a net or seen in a visual survey. Even though this species deposited eggs in this pond, it was not successful in producing viable young at this location. All four of these species were observed in much higher numbers in other ponds and produced viable offspring.

One anuran species not documented in this study, but present on the property is the Fowler's toad, Bufo fowleri (Joe Cichan, coordinator of Frogloggers at Bernheim Forest, personal communication). However, vocalizations of this species were not strong in the last several years (call intensity $=1$; call index range $=0-3$, Frogwatch USA). Out of 12 sites, vocalizations of $B$. fowleri were documented by the Frogloggers at two sites in 2003 and only one site during each visit in 2004, 2005, and 2006. This last remaining site was located approximately $428 \mathrm{~m}$ line-of-sight distance from Backwater 1, but $B$. fowleri was not heard or seen at any of the backwater ponds during this study. All other anuran species listed by the Frogloggers were documented in this study by eggs, larvae and/or adults (Table 5).

None of the values for diversity changed significantly from year to year (Table 6). In addition, there was no significant difference in diversity between the backwater ponds $(\mathrm{n}=6)$ and the upland forest ponds $(\mathrm{n}=5$; Mann-Whitney $U=28, \mathrm{df}=7, p=0.106)$ or among backwater ponds $(\mathrm{n}=6)$ between the two years (Wilcoxon paired-sample test; $t=$ 
$8, p=0.688)$. Yoe Rd. Pond was the one upland forest pond that was sampled in both years, and it increased in diversity from $H=0.20$ in 2005 to $H=0.93$ in 2006 .

Also in 2005, a small depression about $5 \mathrm{~m}$ from Yoe Rd. Pond filled and retained water for most of the spring. This pool was full of $R$. sylvatica egg masses and tadpoles, most of which metamorphosed before the pool dried in late May. Only a few R. sylvatica egg masses were laid in the pond itself. However in 2006, this depression never filled with water and all of the $R$. sylvatica egg masses were laid in the pond. Therefore, the number of $R$. sylvatica documented in the pond itself varied greatly from 2005 to 2006 . In 2005, 69 egg masses were recorded in the pond and no tadpoles were netted. In 2006, 178 egg masses were recorded in the pond, and 131 tadpoles were netted. In addition, hundreds of $R$. sylvatica tadpoles were seen floating near the surface of the water on warm sunny days in 2006 .

Larval abundances were used to separate ponds based on species using PCA and the first two axes explained $87.6 \%$ of the variance (Table 7). Ponds grouped as expected with the backwater ponds together as ponds with very low larval abundance, and most of the upland ponds grouped together as ponds with high larval abundance (Figure 18). However, Yoe Rd. Pond separated out by itself due to the large number of Bufo americanus (American toad) tadpoles that were sampled from that pond. 
Table 4. Species richness at each pond in 2005 and 2006 at Bernheim Arboretum and Research Forest, Clermont, Kentucky. All records are eggs or larvae unless otherwise noted as adult (A). BW = backwater pond.

\begin{tabular}{|c|c|c|c|c|c|c|c|c|c|}
\hline \multirow[t]{2}{*}{ Amphibian Species } & \multicolumn{9}{|c|}{2005} \\
\hline & BW 1 & BW 2 & BW 3 & BW 4 & BW 5 & BW 6 & Yoe Rd & Pond 5 & Pond 8 \\
\hline Ambystoma jeffersonianum & & & & & & & $\mathrm{X}$ & $\mathrm{X}$ & $\mathrm{X}$ \\
\hline Ambystoma maculatum & & & & & & $\mathrm{X}$ & $X$ & $\mathrm{X}$ & $\mathrm{X}$ \\
\hline Ambystoma opacum & & & & & & & & $\mathrm{X}$ & \\
\hline Notophthalmus viridescens & & & & & & & & $X(A)$ & $\mathrm{X}(\mathrm{A})$ \\
\hline Bufo americanus & $\mathrm{X}$ & $\mathrm{X}$ & $\mathrm{X}$ & & $\mathrm{X}$ & $\mathrm{X}$ & $\mathrm{X}$ & $\mathrm{X}$ & $\mathrm{X}$ \\
\hline Pseudacris crucifer & & & & & & & & $\mathrm{X}$ & $\mathrm{X}$ \\
\hline Pseudacris brachyphona & & & & & & & $\mathrm{X}(\mathrm{A})$ & & \\
\hline Acris crepitans blanchardi & & & & & & & $\mathrm{X}(\mathrm{A})$ & & $\mathrm{X}$ \\
\hline Hyla chrysoscelis & $\mathrm{X}$ & & $X$ & $\mathrm{X}$ & $\mathrm{X}$ & $X$ & $\mathrm{X}$ & $\mathrm{X}$ & $\mathrm{X}$ \\
\hline Rana catesbeiana & & & & & & $\mathrm{X}$ & & $\mathrm{X}$ & $\mathrm{X}$ \\
\hline Rana clamitans & $\mathrm{X}$ & $X$ & $\mathrm{X}$ & $\mathrm{X}$ & $\mathrm{X}$ & $\mathrm{X}$ & $\mathrm{X}(\mathrm{A})$ & $\mathrm{X}$ & $\mathrm{X}$ \\
\hline Rana sylvatica & & & & & & & $\mathrm{X}$ & $\mathrm{X}$ & $\mathrm{X}$ \\
\hline Rana sphenocephala & $\mathrm{X}$ & $\mathrm{X}$ & & $\mathrm{X}$ & $\mathrm{X}$ & $\mathrm{X}$ & $\mathrm{X}$ & $\mathrm{X}$ & $\mathrm{X}$ \\
\hline Rana palustris & $\mathrm{X}$ & & & $\mathrm{X}$ & $\mathrm{X}$ & $\mathrm{X}$ & $\mathrm{X}(\mathrm{A})$ & $\mathrm{X}(\mathrm{A})$ & \\
\hline TOTAL \#SPECIES & 5 & 3 & 3 & 4 & 5 & 7 & 10 & 12 & 11 \\
\hline
\end{tabular}


Table 4. continued

\begin{tabular}{|c|c|c|c|c|c|c|c|c|c|}
\hline & \multicolumn{9}{|c|}{2006} \\
\hline & BW 1 & BW 2 & BW 3 & BW 4 & BW 5 & BW 6 & Yoe Rd & Pond 2 & Pond 12 \\
\hline Ambystoma jeffersonianum & $X^{*}$ & & & & & & $\mathrm{X}$ & $\mathrm{X}$ & $\mathrm{X}$ \\
\hline Ambystoma maculatum & $\mathrm{X}^{*}$ & & & $\mathrm{X}^{*}$ & $\mathrm{X}^{*}$ & $\mathrm{X}$ & $X$ & $X$ & $X$ \\
\hline \multicolumn{10}{|l|}{ Ambystoma opacum } \\
\hline Notophthalmus viridescens & $\mathrm{X}(\mathrm{A})^{*}$ & & & & & $\mathrm{X}(\mathrm{A})^{*}$ & & $\mathrm{X}(\mathrm{A})$ & $\mathrm{X}(\mathrm{A})$ \\
\hline Bufo americanus & $\mathrm{X}$ & $* *$ & $* *$ & $\mathrm{X}^{*}$ & $\mathrm{X}$ & $\mathrm{X}$ & $X$ & $\mathrm{X}$ & \\
\hline Pseudacris crucifer & $X(A)^{*}$ & & & $\mathrm{X}(\mathrm{A})^{*}$ & & & & & \\
\hline Pseudacris brachyphona & & & & & & & $* *$ & & \\
\hline Acris crepitans blanchardi & $\mathrm{X}(\mathrm{A})^{*}$ & & & & $\mathrm{X}(\mathrm{A})^{*}$ & & $* *$ & & \\
\hline Hyla chrysoscelis & $* *$ & & $\mathrm{X}$ & $* *$ & $* *$ & $* *$ & $X$ & $X$ & \\
\hline Rana catesbeiana & & & $X^{*}$ & & $\mathrm{X}^{*}$ & $X$ & & $X$ & $X$ \\
\hline Rana clamitans & $\mathrm{X}$ & $\mathrm{X}$ & $\mathrm{X}$ & $\mathrm{X}$ & $\mathrm{X}$ & $\mathrm{X}$ & $X$ & $X$ & $X$ \\
\hline Rana sylvatica & & & & & & $X^{*}$ & $\mathrm{X}$ & $\mathrm{X}$ & $\mathrm{X}$ \\
\hline Rana sphenocephala & $\mathrm{X}$ & $\mathrm{X}$ & $\mathrm{X}^{*}$ & $\mathrm{X}$ & $\mathrm{X}$ & $\mathrm{X}$ & $X$ & $X$ & $\mathrm{X}$ \\
\hline Rana palustris & $\mathrm{X}$ & $X^{*}$ & $\mathrm{X}^{*}$ & $X$ & $X$ & $X^{*}$ & $\mathrm{X}$ & $X$ & \\
\hline \begin{tabular}{|c|} 
TOTAL \#SPECIES \\
\end{tabular} & 9 & 3 & 5 & 6 & 7 & 8 & 8 & 10 & 7 \\
\hline
\end{tabular}

* = new species since 2005

** = species documented in 2005 
Table 5. Anuran species documented at Bernheim Arboretum and Research Forest, Clermont, Kentucky in 2005 and 2006 by call surveys conducted by Frogloggers of Bernheim Forest.

\begin{tabular}{ll}
\hline Latin name & Common name \\
\hline Bufo americanus & American toad \\
Bufo fowleri* & Fowler's toad \\
Acris crepitans & Cricket frog \\
Pseudacris brachyphona & Mountain chorus frog \\
Pseudacris crucifer & Spring peeper \\
Hyla chrysoscelis & Cope's gray treefrog \\
Rana catesbeiana & Bullfrog \\
Rana clamitans & Green frog \\
Rana palustris & Pickerel frog \\
Rana sphenocephala & S. leopard frog \\
Rana sylvatica & Wood frog \\
\hline * only anuran species not documented in this study
\end{tabular}

Table 6. Shannon's diversity indices, direction of change from year to year, and net change in species richness for each pond sampled in 2005 and 2006 at Bernheim Arboretum and Research Forest, Clermont, Kentucky. BW = backwater pond.

\begin{tabular}{lcccc} 
Pond name & \multicolumn{2}{c}{ Year } & $\begin{array}{c}\text { Diversity } \\
\text { direction }\end{array}$ & $\begin{array}{c}\text { net\# spp } \\
\text { added }\end{array}$ \\
\hline BW1 & 0.913 & 0.643 & down & 4 \\
BW2 & 0.985 & 0.978 & down & 0 \\
BW3 & 0.468 & 1.378 & up & 2 \\
BW4 & 1.061 & 1.156 & up & 2 \\
BW5 & 1.062 & 1.693 & up & 2 \\
BW6 & 1.724 & 1.230 & down & 2 \\
Yoe Rd. & 0.200 & 0.932 & up & -2 \\
Pond \#2 & - & 1.563 & N/A & N/A \\
Pond \#5 & 1.511 & - & N/A & N/A \\
Pond \#8 & 1.793 & - & N/A & N/A \\
Pond \#12 & - & 1.836 & N/A & N/A \\
\hline
\end{tabular}


Table 7. Eigenvalues for the four axes (AX $1-4)$ of the PCA ordination used in grouping ponds according to amphibian larval abundance and the species scores of those larvae. Ambystoma species includes A. maculatum and A. jeffersonianum.

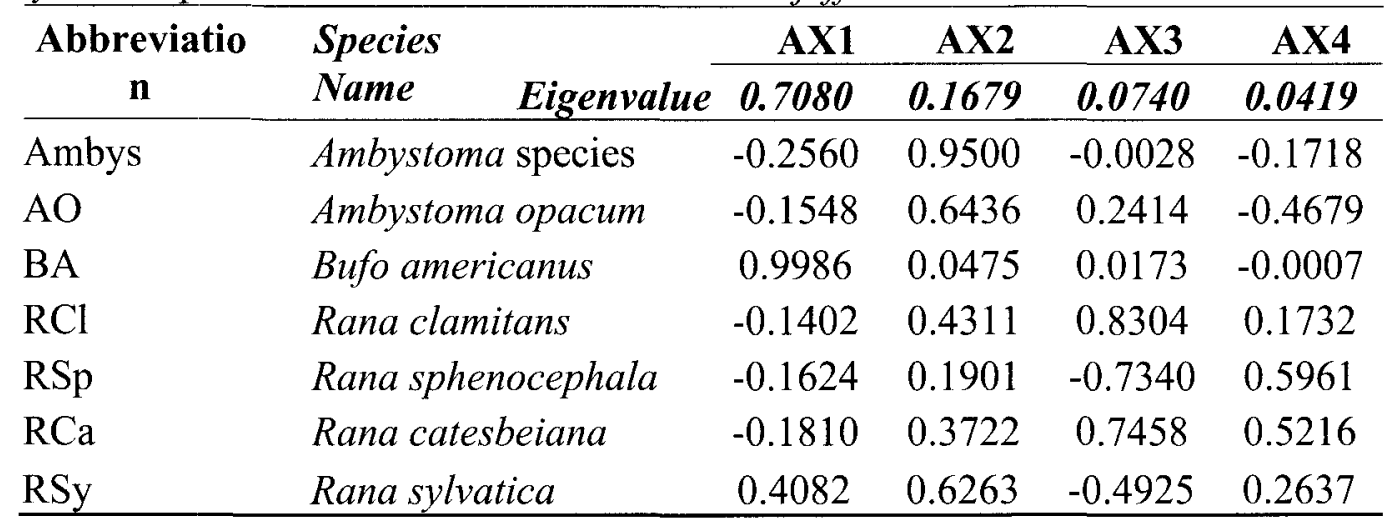

The small, scattered mostly ephemeral pools in the floodplain of Wilson Creek housed mainly B. americanus and Hyla chrysoscelis (Cope's gray treefrog), although I did not collect abundance data. I observed a few ranid tadpoles in 2005 , but it is likely that they washed in from other sources because ranid egg masses, which would have been easily visible if present, were not observed prior to tadpole arrival. Also, the ranid tadpoles netted were too large to have developed in the pools, even if eggs had been laid and hatched between visits. However in 2006, in addition to the large numbers of $B$. americanus and $H$. chrysoscelis eggs, $R$. sphenocephala egg masses were observed in three of the pools that were semi-permanent (only dry $4 \%$ of the time) and slightly deeper than the other 12 pools (personal observation). Backwaters 1, 5 and 6 had B. americanus eggs and tadpoles in both years also, but not in the same quantity as in the pools. I observed this species on $71 \%$ of the visits to backwater ponds and $89 \%$ of the time in the ephemeral pools. In 2005, Backwater 4 had H. chrysoscelis egg masses, but none of the other backwater ponds were observed to contain this species in either year. I observed $H$. 
chrysoscelis in the backwater ponds $11 \%$ of the time I visited them and $35 \%$ of the time in the ephemeral pools. Therefore, these pools were important breeding sites for at least one anuran species (H. chrysoscelis) that did not use the backwaters to the same degree as the small, scattered ephemeral pools. Future abundance data for B. americanus may reveal that even though this species was found in both habitat types on many of the same occasions, the reproductive effort may be greater in the ephemeral pools.

\section{How physical and chemical factors affect amphibian assemblage}

Because the larger scores for the physical and chemical parameters in the PCA ordination are proportional to the amount of variation they explain, $\mathrm{pH}$ and conductivity were tested against species richness and abundance in linear regressions to determine any significant correlations. $\mathrm{pH}$ and conductivity were significantly negatively correlated with species richness and abundance in the ponds (Table 8). As $\mathrm{pH}$ and conductivity increase, species richness and abundance decrease (Figure 19). Backwater ponds had higher $\mathrm{pH}$ and conductivity and lower species richness and abundance than the upland forest ponds.

The backward linear regression of physical factors compared to species richness and abundance resulted in elevation as the only significant correlation. The variation in species richness was not highly explained by the variation of the physical parameters $\left(r^{2}\right.$ $=0.47)$, but elevation was significantly correlated with species richness $\left(\mathrm{F}_{9,10}=8.112, p=\right.$ 0.019). In contrast, the variation in abundance was highly explained by the variation in the physical parameters $\left(r^{2}=0.91\right)$, but again, elevation was the only significantly correlated factor $\left(\mathrm{F}_{9,10}=87.006, p<0.0001\right)$. 


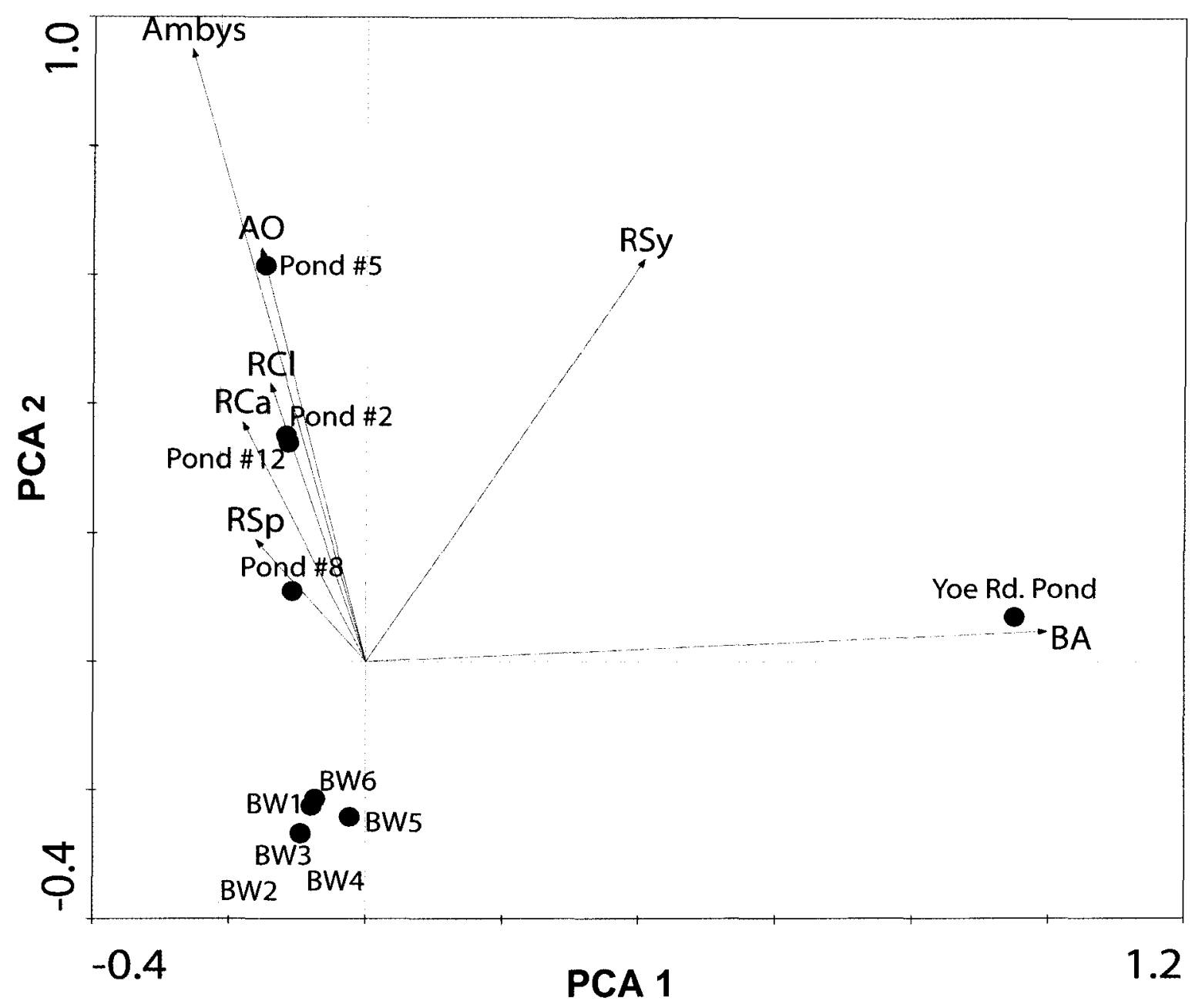

Figure 18. Principle component analysis (PCA) ordination depicting relationships among abundances of amphibian species and ponds sampled. The length of the arrow illustrates the strength in relationship to the pond toward which it is pointing. $\mathrm{BW}=$ backwater pond. See Table 6 for explanation of other terms. 
Table 8. Results of a linear regression test to determine correlation of pond characteristics with species richness and abundance (capture rate) at ponds.

\begin{tabular}{|c|c|c|}
\hline Test & $\begin{array}{c}\text { Species } \\
\text { richness }\end{array}$ & Abundance \\
\hline$R^{2}$ & 0.602 & 0.903 \\
\hline \multicolumn{3}{|l|}{ ANOVA } \\
\hline $\mathrm{F}_{8,10}$ & 6.061 & 37.222 \\
\hline $\mathrm{p}$-value & 0.025 & $<0.0001$ \\
\hline \multicolumn{3}{|l|}{$\mathrm{pH}$} \\
\hline $\begin{array}{c}\quad \mathrm{F}_{9,10} \\
p \text {-value } \\
\text { conductivity }\end{array}$ & $\begin{array}{c}13.446 \\
0.005\end{array}$ & $\begin{array}{c}76.358 \\
<0.0001\end{array}$ \\
\hline $\mathrm{F}_{9,10}$ & 10.967 & 45.243 \\
\hline$p$-value & 0.009 & $<0.0001$ \\
\hline
\end{tabular}
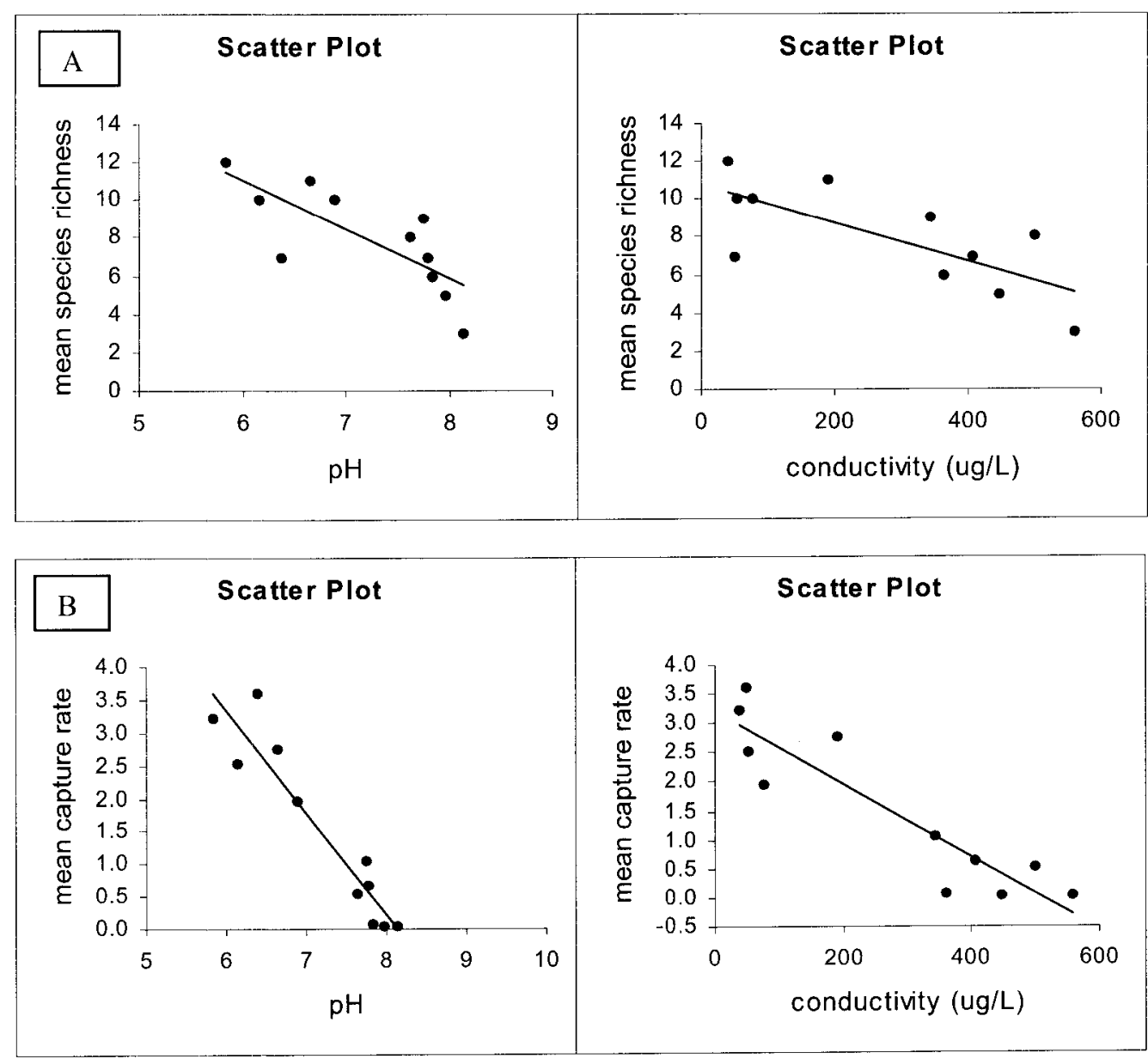

Figure 19. Results of linear regression tests demonstrating that as $\mathrm{pH}$ and conductivity increase, A) species richness and B) capture rate (abundance) decreases. 


\section{Potential predators}

$\underline{\text { Fish }}$

All backwater ponds contained fish in both years. In 2005, the only upland pond in which fish were observed was Yoe Rd. Pond. In 2006, I did not sample Pond \#5 and Pond $\# 8$ due to lack of fish while I added Pond $\# 2$ and $\# 12$ because they were thought to contain fish. However, a field assistant and I did not observe fish in either Pond \#2 or \#12 in 2006. Also, we did not observe fish at any time during 2006 in Yoe Rd. Pond, and the water clarity was lower than in 2005 . Because we saw large fish swimming in Yoe Rd. Pond in 2005, we do not know whether or not they were present in 2006 or if the water clarity prevented observation of fish that may have been present. Water clarity was low ị Pond \#2 and Pond \#12 also, so even though no fish were documented in these ponds, there is no conclusive evidence that fish were absent.

\section{$\underline{\text { Invertebrates }}$}

Dragonfly naiads, crayfish, snails, and isopods were recorded in Backwaters $1-6$ and Yoe Rd. Pond. Four other ponds sampled contained dragonfly naiads as well, and crayfish were documented in every pond except Pond \#8. Yoe Rd. Pond was the only pond sampled where leeches were documented, and these can deter the presence of some amphibians such as $N$. viridescens (Gill 1978).

\section{Others}

We observed snakes and turtles in or near some of the ponds during the two seasons of sampling. I saw an eastern garter snake (Thamnophis sirtalis sirtalis) at the water's edge of Backwater 1 in 2005. I saw northern water snakes (Nerodia sipedon 
sipedon) in Backwater 5 on one occasion and in Yoe Rd. Pond and Pond \#12 during two separate visits at each pond. We saw a juvenile snapping turtle (Chelydra serpentina) in Backwater 2 in 2006 during sampling, and I saw juvenile of this species at the one backwater pond that was continuously connected to the stream and therefore not officially sampled during this study. It is probable that an adult snapping turtle was in Pond \#2 in 2006, but this could not be confirmed. None of these reptiles were observed actively consuming any amphibians at any time. 


\section{DISCUSSION}

\section{Amphibian composition}

Over both years of the study, upland forest ponds had higher species richness and abundance than the backwater ponds. The backwater ponds increased in species richness from 2005 to 2006, but not in abundance. The larvae of some species were never netted in the backwater ponds, even though egg masses were documented (e.g., $A$. jeffersonianum and $R$. sylvatica). Conversely, some species seemed to thrive in these backwater ponds. Many egg masses of $R$. sphenocephala were observed, and tadpoles of this species were caught in relatively large numbers. B. americanus did not breed heavily in these ponds, but metamorphosed toadlets were documented on many of their shores. Even though many amphibian species used the backwater ponds as breeding sites within three years of their creation, it is possible that these ponds are acting as population sinks in some cases because eggs laid are not always producing viable offspring. This is part of the difficulty in determining whether or not a restoration project is "successful."

It is becoming increasingly clear that natural amphibian population fluctuations must be addressed when discussing decline of this taxon. Yoe Rd. Pond is at least 30 years old, but its species richness, diversity and abundance all decreased in 2006 from 2005. A two-year study is not sufficient to document a decline because many factors can

affect population fluctuations in a particular pond, e.g., weather (Pechmann et al. 1991) 
or amphibians existing in a metapopulation (Marsh and Trenham 2001). Similarly, a two-year study is not sufficient to document whether or not a restoration is successful. The fact that the backwater ponds are adding new species even after three years of being created shows that long-term monitoring is required for full understanding of the system in question.

There was no difference in diversity between pond types or in backwater ponds from year to year. Diversity indices take into account species richness and abundance, so even though Backwater 1 added four species in 2006, for example, the abundance of these species was very low, thereby decreasing the diversity value. Conversely, the diversity value for Yoe Rd. Pond increased from $H=0.2$ in 2005 to $H=0.9$ in 2006 . Even though the species richness did not change dramatically $(2005: \mathrm{n}=10,2006: \mathrm{n}=8)$, the number of larval species caught doubled $(2005: n=3,2006: n=6)$. For example, the R. sylvatica that bred in the ephemeral pool near Yoe Rd. Pond in 2005 were forced to lay eggs in the pond itself in 2006. Similarly, a few species that I documented by the presence of egg masses or adults in 2005 were documented by dip-netting larvae in 2006. With a higher number of species and a more even abundance, the diversity value increased for this pond.

\section{Physical characteristics}

Backwater ponds and upland forest ponds did not differ significantly in perimeter size or maximum water depth, but backwater ponds tended to be larger and shallower. Even though Backwaters $1-3$ were much larger $(\mathrm{x}=224.3 \mathrm{~m})$ than the other ponds sampled $(\mathrm{x}$ $=59.4 \mathrm{~m}$ ), pond size was not correlated with species richness or abundance. This agrees 
with the finding by Snodgrass et al. (2000b) who found that wetland size did not determine amphibian species richness.

Backwater ponds and upland forest ponds differed significantly in the distance to a forest edge and elevation. Even though distance to forest edge was not significantly correlated with species richness or abundance, the backwater ponds were on average closer to the forest edge than the upland forest ponds, possibly causing an "edge effect" that may influence amphibian assemblage. In addition, the forest edge at the backwater ponds is next to a valley field (Figure 1). The edge for many of the upland forest ponds is a gravel road not highly utilized by vehicular traffic and is not as wide as the valley field. The open valley field is most likely a larger obstacle for dispersing amphibians than the gravel road with higher canopy cover. Proximity of breeding ponds to terrestrial forested habitat is critical for many amphibians to complete their life cycle (Calhoun et al. 2003, Semlitsch and Bodie 1998), so fragmentation can hinder amphibian movement between their breeding ponds and terrestrial habitats. Forest fragment size can significantly impact the number of species found in an area, and some species have critical thresholds for fragment size (Vallan 2000). deMaynadier and Hunter (1998) reported that abundance of 13 amphibian species significantly increased with increased distance from a forest edge, but not all species of amphibians were affected in the same way. In general, salamanders avoided edges more often than anurans, but there were exceptions, e.g., $R$. sylvatica was more abundant in the interior of forests. In contrast to the finding that salamanders avoid edges, some salamander species such as $A$. maculatum and $A$. opacum cross open areas to access breeding ponds (Gibbs 1998). The area in and around 
Bernheim Forest is not severely fragmented, but some open fields exist on the property as well as a few gravel or asphalt roads.

Even though the backwater ponds are bordered by forest on the southeast side, the nearest potential source ponds for amphibians are located north and west over a creek, through a field and over a hill of about $30 \mathrm{~m}$. The other option for travel of amphibians from these ponds is following a paved road around the knob. These ponds were not sampled and the habitat is different, but these are the nearest ponds to the backwater ponds. The upland forest ponds are mostly on the ridgetop and not near paved roads. Travel between these ponds is through contiguous forest in most cases, and most roads near these ponds are gravel and are rarely subjected to vehicular traffic. In other words, the backwater ponds are relatively isolated from potential source ponds and it will take time for them to be colonized by sustained populations of pond-breeding amphibians.

\section{Water chemistry}

Although water chemistry parameters are not excellent predictors of amphibian species richness (Hecnar and M'Closkey 1996), several authors have found that some species are correlated with particular nutrients or conditions. Beebee (1983) found that some species of newt were allopatrically distributed based on $\mathrm{pH}$ and that the rare Bufo calamita (Natterjack toad) prefers neutral pH (5 - 7) and low conductivity levels (64 - 96 $\mu \mathrm{S} / \mathrm{cm}$ ). Even though amphibians as a group are relatively acid tolerant (Pierce 1985), Horne and Dunson (1995) reported that low pH in conjunction with other abiotic factors (e.g., toxic metals and high DOC) could negatively affect $A$. jeffersonianum, $A$. maculatum, and R. sylvatica. Not only can abiotic factors affect amphibians directly, 
they can combine to decrease food sources in the form of primary and secondary productivity.

Abiotic factors in this study I found to be negatively correlated with species richness and abundance were $\mathrm{pH}$ and conductivity. The backwater ponds are at lower elevation and are situated over limestone for the most part (Figure 6). Limestone contains calcium carbonate that acts as a buffer in solution causing the water to be more alkaline (i.e., $\mathrm{pH}>7$ ). The upland forest ponds are at higher elevation where sandstone is more prevalent. Without the buffering effect of limestone, $\mathrm{pH}$ was lower in the upland forest ponds. Therefore, the upland forest ponds are significantly slightly acidic (i.e., $\mathrm{pH}$ $<7$ ). However, the $\mathrm{pH}$ levels recorded in the ponds (range: $\mathrm{pH} 5.65-8.31$ ) would not be a source of mortality for the species encountered (Pierce 1985), so $\mathrm{pH}$ cannot be considered a limiting factor for amphibian colonization.

The difference in conductivity levels between the backwater and upland forest ponds was highly significant, but most studies report that this parameter is not a good predictor of amphibian assemblages (Campbell et al. 2004, Lehtinen and Galatowitsch 2001, Petranka et al. 2003b). Also, amphibians exist in a wide range of conductivity levels. For example, Hecnar and M'Closkey (1996) reported amphibians in conductivity levels of $124-3100 \mu \mathrm{S} / \mathrm{cm}$. The lowest reading taken at a pond in this study was 38.5 $\mu \mathrm{S} / \mathrm{cm}$ (Pond \#5), but the highest was $559.7 \mu \mathrm{S} / \mathrm{cm}$ (Backwater 2). Interestingly, Pond \#5 had the highest species richness $(n=12)$ and Backwater 2 had the lowest $(n=3)$. Capture rate as a measure of abundance for these two ponds was very different as well (Pond \#5 $=3.21$ larvae/swcep vs. Backwater $2=0.05$ larvae/sweep). Conductivity is a measurement of the amount of ions in the water, which can affect aquatic species. 
Because ions flow from a level of high concentration to low concentration, either extreme in the water can be detrimental. If the water has high conductivity, ions such as salt can pass into an aquatic organism resulting in the upset of the organism's ionic balance. Similarly, if the water has a very low reading of conductivity, ions inside the organism can pass out of the organism and into the water, again disturbing the ionic balance inside the organism. Not only can this phenomenon affect amphibians themselves, but it can also affect insect communities in the water, and this is important because insects can be a source of food or predation for amphibians. Batzer et al. (2004) reported that, like amphibians, macroinvertebrate communities were not strongly correlated with chemical attributes of the water, but a few families were positively related to conductivity levels. Other factors could combine to result in these differences between Pond \#5 and Backwater 2, but conductivity may be an important one.

The backwater ponds possessed characters that have been shown to deter amphibian use, but because these are new habitats with their biotic and abiotic factors still in flux, time will possibly allow for more suitable conditions to arise.

\section{Combination of factors}

Many physical, chemical and biological factors combine to determine the faunal and floral composition of a pond or wetland (Brodman et al. 2003, Hecnar and M'Closkey 1998, Skelly et al. 1999, Travis et al. 1985, Wilber 1987). The pond types in this study differed in physical characteristics, such as size and distance to the edge of the forest, and in some water chemistry parameters (i.e., $\mathrm{pH}$ and conductivity). Pond size or conductivity readings individually may not determine amphibian assemblage on their 
own, but combined with each other, predator pressure and food availability (to name a few), they may help determine which species are present and in what abundance.

\section{Pools}

The mostly ephemeral pools near the backwater ponds were not formally sampled as part of this study, but they were monitored for species richness as part of monitoring success of the stream restoration. Hydroperiod of ponds is a strong determinant of amphibian assemblage (Houlahan and Findlay 2003, Petranka et al. 2003a, Skelly et al. 1999). Fish and some invertebrate larvae that are predators of amphibian larvae cannot survive in ephemeral or vernal bodies of water. Also, canopy cover was low or nonexistent for many of these pools, and the majority were very shallow. This resulted in high levels of solar exposure and very warm water. Also, some species of amphibians develop very quickly and are suited to this type of ephemeral habitat. The main species found in these pools were $H$. chrysoscelis and B. americanus. Wilber (1987) experimentally demonstrated that $H$. chrysoscelis survived poorly in slow-drying ponds. He also reported that this species takes advantage of small, recently filled pools that contain nutrients from runoff or those released from decomposed material. Many of the pools sampled dried and filled multiple times through the summer, providing ideal habitat for breeding H. chrysoscelis. B. americanus tadpoles are unpalatable to fish (Heyer et al. 1975), but they prefer warm shallow water (Houlahan and Findlay 2003). This species also does poorly in high-density communities (Wilber 1987). Because these pools only supported a few species that laid viable eggs, the density of tadpoles may have been 
lower compared to ponds with a greater number of successfully reproducing species, therefore providing preferable habitat for B. americanus.

\section{Predators}

\section{$\underline{\text { Fish }}$}

It is well documented that predatory fish can deter some amphibians from breeding in ponds where they exist (Hecnar and M'Closkey 1997, Hero et al. 2001, Kats et al. 1988, Semlitsch 2002), especially if they are non-native, introduced species of fish (Bradford 1989, Fellers and Drost 1993, Gamradt and Kats 1996). Some amphibian species that coexist with fish have larvae that exhibit anti-predator behaviors (e.g., seeking refuge in shallow water) or are unpalatable to fish (Heyer et al. 1975, Kats et al. 1988, Semlitsch 2002). In this study, amphibian species such as Ambystoma sp. that are typically found in semi-permanent or temporary ponds (Hecnar and M'Closkey 1997) were present in the permanent ponds. However, there were more A. maculatum egg masses than A. jeffersonianum overall. The larvae of both species are palatable to fish, but the jelly of $A$. maculatum egg masses is thicker than that of $A$. jeffersonianum and may help to protect them from fish predation (Semlitsch 1988). Not all fish are predators of amphibian eggs and/or larvae (Hecnar and M'Closkey 1997), and it is not known if those in the ponds at Bernheim Forest are predatory or not. However, because the backwater ponds were formed from a stream, the species composition of fish may be different than in the upland ponds that are not associated with creeks or streams. 


\section{Invertebrates}

Invertebrate adults and/or larvae can compete directly or indirectly with amphibians for food (Morin et al. 1988), and they can also be a source of predation on larval amphibians (Brodie et al. 1978, Hero et al. 2001, Smith 1983). It is well known that odonate larvae predate amphibian larvae (Brodie et al. 1978, Gill 1978, Hero et al. 2001, Heyer et al. 1975, Smith 1983) and dragonfly naiads were documented in every pond sampled in both years. Even amphibian species that are unpalatable to fish are predated upon by odonates (Hero et al. 2001). Some invertebrate larvae also compete directly and indirectly with amphibian larvae for resources such as food and nutrients (Morin et al. 1988).

Crayfish are also amphibian predators (Fauth 1990, Nyström et al. 2001) and adult and juvenile crayfish were documented in all ponds except Pond \#8. The presence of juveniles indicates that crayfish are reproducing in these ponds as opposed to this predator being a transient or washed in from another source. Dragonfly naiads and crayfish may be important predators in these ponds, but they do not exclude amphibians from breeding in this system.

Gill (1978) reported that amphibian blood leeches (Batrachobdella picta) were an important ectoparasite on adult $N$. viridescens and predators on the larvae of this species. Leeches were considered to contribute to the mortality of $N$. viridescens in the Virginia ponds sampled in that study. Two upland forest ponds sampled in this study that did not contain N. viridescens were Yoe Rd. Pond (both years) and Pond \#8 (2005). Leeches (species unknown) were documented in Yoe Rd. Pond and may have deterred $N$. viridescens from breeding there. Leeches were not documented in Pond \#8, but this pond contained anthropogenic garbage, had very shallow muddy water, and received a great 
deal of solar exposure. The adult aquatic stage of $N$. viridescens is usually found in unpolluted ponds (Conant and Collins 1998), and this pond did not fit that description. Also, this pond was on the edge of a large open field on the north side with thin forest on the south. In a mark-recapture study on edge effects, Gibbs (1998) found $N$. viridescens avoided forest edges, even though they were among the most commonly captured amphibian species. $N$. viridescens was found in two backwater ponds that also are juxtaposed to a large field, but these ponds had some trees on all sides with greater canopy cover than Pond \#8. Also, the forest on the southeast side of the backwaters was much more dense compared to Pond \#8 (personal observation). The combination of garbage in the water and thin forest at this pond may have contributed to the absence of N. viridescens.

\section{Other predators}

Other animals known to predate upon amphibian eggs, larvae and/or adults are snakes (Wassersug and Sperry 1977) and turtles (Hero et al. 2001), and both these reptiles were observed during this study. T. s. sirtalis, $N$. s. sipedon and C. serpentina were seen at one or more of the ponds over the two years of sampling, but none were observed actively consuming any amphibians. These species are strongly associated with water (although T. s. sirtalis occupies varied habitats, it is commonly associated with moist areas) and therefore have a diet consisting largely of aquatic organisms, including frogs, toads and salamanders (Barbour 1971). In Yoe Rd. Pond and Pond \#12, an individual N. s. sipedon was spotted swimming in the water on more than one occasion in 2006 and is likely a significant predator. 


\section{Future work}

Periodic monitoring of the backwater ponds for new amphibian species and for increased abundance is suggested to support the success of the restoration of Wilson Creek. In particular, species such as A. maculatum, A. jeffersonianum, and $R$. sylvatica should be targeted to document viable breeding populations. Call surveys would help confirm breeding species and potentially document $B$. fowerli. Determination of the nearest source pond for these species would assist in our understanding of how much time it may take for these species to become established in these ponds. Better documentation of the invertebrate communities and fish assemblages found in the ponds is also needed. These potential predators could have significant effects on the amphibian assemblage differences between the pond types.

More physical characteristics should be measured, especially those that are important to amphibian egg placement and larvae refuge. Leaf litter depth, detritus type and aquatic vegetation can all be important in breeding choice and survival of larvae. These can have direct effects such as providing cover, or indirect effects by leaching nutrients into the water. Also, the forest communities differ based mainly on elevation changes on the property, and the leaf litter composition in the ponds differs as a result. Because different tree species add different nutrients into the water, investigation into these differences may yield correlations with amphibian species richness and/or abundance.

Because the small ephemeral pools house a different amphibian assemblage than the backwater ponds, these pools should be sampled comparatively to the other pond types. Values for amphibian species richness and abundance, and those for physical and 
chemical measurements for these pools may help explain the differences between them and the other ponds. The juxtaposition of ephemeral pools to permanent ones provides unique habitat to support a variety of species, which contributes to the success of this restoration project.

\section{Conclusions}

The restoration of Wilson Creek provides a mosaic of terrestrial and aquatic habitats for many species. The aquatic habitats include a meandering stream, many ephemeral pools, and several still-water shallow ponds. This study concentrated on the amphibians of the backwater ponds and some comparable upland forest ponds, but the ephemeral pools were also sampled. The new habitats created by the backwater ponds and ephemeral pools now available to breeding amphibians at Bernheim Forest are located on protected property and are surrounded by forested habitat and sparsely scattered rural farms. Backwater ponds may be experiencing a slight edge effect due to their proximity to a valley field, but the overall habitat is not degraded by logging, extensive farming, or other detrimental practices causing severe habitat fragmentation.

Even though $\mathrm{pH}$ and conductivity levels were significantly higher in the backwater ponds compared to the upland forest ponds, all of the parameters tested were within the limits of providing good breeding habitat. Species richness and abundance in the backwater ponds were not as high as in the upland forest ponds, but the backwater ponds did have slightly higher abundance and significantly higher species richness in the second year of the study. Long-term monitoring will reveal whether the backwater ponds become equal in species richness and abundance to the ponds that are $>30$ years old. 
The increase in species richness in the second year is encouraging that the trend is heading toward equality. The ephemeral pools are important breeding habitat for $H$. chrysoscelis and possibly B. americanus. More in-depth study of these pools will reveal their significance in the amphibian community at this site. Time is needed for the backwater ponds and ephemeral pools to develop and support sustainable, healthy populations of anurans and salamanders, but the successful breeding of several species in the backwater ponds suggests success of this stream restoration. Management implications learned from this project are to create and maintain a variety of habitat types including permanent, semi-permanent, and ephemeral water to support the highest number and greatest diversity of amphibians. 


\section{REFERENCES}

Alford, R. A. and S. J. Richards. 1999. Global Amphibian Declines: A Problem in Applied Ecology. Annual Review of Ecological Systematics 30:133-165.

Alford, R. A. and H. M. Wilber. 1985. Priority Effects in Experimental Pond Communities: Competition Between Bufo and Rana. Ecology 66(4):1097-1105.

APHA (American Public Health Association). 1998. Standard Methods for the Examination of Water and Wastewater, 20th edition.

Arntzen, J. W. and S. F. M. Teunis. 1993. A Six Year Study on the Population Dynamics of the Crested Newt (Triturus cristatus) Following the Colonization of a Newly Created Pond. Herpetological Journal 3:99-110.

Barbour, R. W. 1971. Amphibians and Reptiles of Kentucky. University of Kentucky Press, Lexington. 334 pp.

Batzer, D. P., B. J. Palik, and R. Buech. 2004. Relationships Between Environmental Characteristics and Macroinvertebrate Communities in Seasonal Woodland Ponds of Minnesota. J. N. Am. Benthol. Soc. 23(1):50-68.

Beebee, T. J. C. 1983. Habitat Selection by Amphibians across an Agricultural LandHeathland Transect in Britain. Biological Conservation 27:111-124.

Bernheim Arboretum and Research Forest. 2006. http://www.bernheim.org /Default.aspx?tabid=31.

Biebighauser, T. Wetlands. Kentucky Pride. Accessed 11 November 2006. http://www.kypride.org/educators/wetlands.php\#abouttom.

Biebighauser, T. 2002. A Guide to Creating Vernal Ponds: All the Information You Need to Build and Maintain an Ephemeral Wetland. USDA Forest Service, Morehead, Kentucky.

Bradford, D. F. 1989. Allopatric Distribution of Native Frogs and Introduced Fishes in High Sierra Nevada Lakes of California: Implication of the Negative Effect of Fish Introductions. Copeia 1989(3):775-778. 
Brodie, E. D., Jr., D. R. Formanowicz. and E. D. Brodie, III. 1978. The Development of Noxiousness of Bufo americanus Tadpoles to Aquatic Insect Predators. Herpetolgica 34(3):302-306.

Brodman, R., J. Ogger, T. Bogard, A. J. Long, R. A. Pulver, K. Mancuso and D. Falk. 2003. Multivariate Analysis of the Influences of Water Chemistry and Habitat Parameters on the Abundances of Pond Breeding Amphibians. Journal of Freshwater Ecology 18(3):425-436.

Calhoun, A. J. K., R. E. Walls, S. S. Stockwell, and M. McCollough. 2003. Evaluating Vernal Pools as a Basis for Conservation Strategies: A Maine Case Study. Wetlands 23(1):70-81.

Campbell, C. E., I. G. Warkentin, and K. G. Powell. 2004. Factors Influencing the Distribution and Potential Spread of Introduced Anurans in Western Newfoundland. Northeastern Naturalist 11(2):151-162.

Conant, R. and J. T. Collins. 1998. Reptiles and Amphibians: Eastern/Central North America. Peterson Field Guides. Houghton Mifflin, New York. 606 pp.

Corser, J. D. 2001. Decline of Disjunct Green Salamander (Aneides aeneus) Populations in the Southern Appalachians. Biological Conservation 97:119-126.

Delis, P. R., H. R. Mushinsky, and E. D. McCoy. 1996. Decline of Some West-Central Florida Anuran Populations in Response to Habitat Degradation. Biodiversity and Conservation 5:1579-1595.

deMaynadier, P. G. and M. L. Hunter, Jr. 1998. Effects of Silvicultural Edges on the Distribution and Abundance of Amphibians in Maine. Conservation Biology 12(2):340-352.

Denton, J. S., S. P. Hitchings, T. J. C. Beebee, and A. Gent. 1997. A Recovery Program for the Natterjack Toad (Bufo calamita) in Britain. Conservation Biology 11(6):1329-1338.

Dodd, C. K. and R. A. Seigel. 1991. Relocation, Repatriation, and Translocation of Amphibians and Reptiles: Are They Conservation Strategies That Work? Herpetologica 47(3):336-350.

Fauth, J. E. 1990. Interactive Effects of Predators and Early Larval Dynamics of the Treefrog Hyla chrysoscelis. Ecology 71(4):1609-1616.

Fellers, G. and C. A. Drost. 1993. Disappearance of the Cascades frog Rana cascadae at the Southern End of Its Range, California, USA. Biological Conservation 65:177181 .

Frogwatch USA. Accessed 20 November 2006. http://www.nwf.org/frogwatchUSA/. 
Gamradt, S. C. and L. B. Kats. 1996. Effect of Introduced Crayfish and Mosquitofish on California Newts. Conservation Biology 10(4):1155-1162.

Gibbs, J. P. 1998. Amphibian Movements in Response to Forest Edges, Roads, and Streambeds in Southern New England. Journal of Wildlife Management 62(2):584-589.

Gibbs, J. P., S. Droege and P. Eagle. 1998. Monitoring Populations of Plants and Animals. Bioscience 48(11):935-940.

Gill, D. E. 1978. The Metapopulation Ecology of the Red-Spotted Newt, Notophthalmus viridescens (Rafinesque). Ecological Monographs 48(2):145-166.

Hecnar, S. J. and R. T. M'Closkey. 1996. Amphibian Species Richness and Distribution in Relation to Pond Water Chemistry in South-western Ontario, Canada. Freshwater Biology 36:7-15.

Hecnar, S. J. and R. T. M'Closkey. 1997. The Effects of Predatory Fish on Amphibian Species Richness and Distribution. Biological Conservation 79:123-131.

Hecnar, S. J. and R. T. M'Closkey. 1998. Species Richness Patterns of Amphibians in Southwestern Ontario Ponds. Journal of Biogeography 25:763-772.

Hero, J-M., W. E. Magnusson, C. F. D. Rocha, and C. P. Catterall. 2001. Antipredator Defenses Influence the Distribution of Amphibian Prey Species in the Central Amazon Rain Forest. Biotropica 33(1):131-141.

Heyer, W. R., R. W. McDiarmid, and D. L. Weigmann. 1975. Tadpoles, Predation and Pond Habitats in the Tropics. Biotropica 7(2):100-111.

Homoya, M. A. 1999. Bernheim Forest - Map of Vegetation Alliances. Obtained from Bernheim Arboretum and Research Forest, Clermont, Kentucky.

Horne, M. T. and W. A. Dunson. 1995. The Interactive Effects of Low pH, Toxic Metals, and DOC on a Simulated Temporary Pond Community. Environmental Pollution 89(2):155-161.

Houlahan, J. E. and C. S. Findlay. 2003. The Effects of Adjacent Land Use on Wetland Amphibian Species Richness and Community Composition. Canadian Journal of Aquatic Sciences 60:1078-1094.

Kats, L. B., J. W. Petranka, and A. Sih. 1988. Antipredator Defenses and the Persistence of Amphibian Larvae with Fishes. Ecology 69(6):1865-1870.

Lehtinen, R. M. and S. M Galatowitsch. 2001. Colonization of Restored Wetlands by Amphibians in Minnesota. American Midland Naturalist 145:388-396. 
Liu, H., S. Zhang, A. Li, X. Lu, and Q. Yang. 2004. Impacts on Wetlands of Large-scale Land-use Changes by Agricultural Development: The Small Sanjiang Plain, China. Ambio 33(6):306-310.

Marsh, D. M. 2001. Fluctuations in Amphibian Populations: A Meta-Analysis. Biological Conservation 101:327-335.

Marsh, D. M. and P. C. Trenham. 2001. Metapopulation Dynamics and Amphibian Conservation. Conservation Biology 15(1):40-49.

Mitsch, W. J. and R. F. Wilson. 1996. Improving the Success of Wetland Creation and Restoration with Know-How, Time and Self-Design. Ecological Applications 6(1):77-83.

Montalvo, A. M., S. L Williams, K. J. Rice, S. L. Buchmann, C. Cory, S. N. Handel, G. P. Nabhan, R. Primack, R. H. Robichaux. 1997. Restoration Biology: A Population Biology Perspective. Restoration Ecology 5(4):277-290.

Morin, P. J. 1987. Predation, Breeding Asynchrony, and the Outcome of Competition Among Treefrog Tadpoles. Ecology 68(3):675-683.

Morin, P. J., S. P. Lawler, and E. A. Johnson. 1988. Competition Between Aquatic Insects and Vertebrates: Interaction Strength and Higher Order Interactions. Ecology 69(5):1401-1409.

Nyström, P., O. Svensson, B. Lardner, C. Brönmark, and W. Granéli. 2001. The Influence of Multiple Introduced Predators on a Littoral Pond Community. Ecology 82(4):1023-1039.

Pechmann, J. H. K., D. E. Scott, R. D. Semlitsch, J. P. Caldwell, L. J. Vitt, and J. W. Gibbons. 1991. Declining Amphibian Populations: The Problem of Separating Human Impacts from Natural Fluctuations. Science 253:892-895.

Pechmann, J. H. K. and H. M. Wilber. 1994. Putting Declining Amphibian Populations in Perspective: Natural Fluctuations and Human Impacts. Herpetologica 50(1):6584.

Pechmann, J. H. K., R. A. Estes, D. E. Scott, and J. W. Gibbons. 2001. Amphibian Colonization and Use of Ponds Created for Trial Mitigation of Wetland Loss. Wetlands 21(1):93-111.

Petranka, J. W., S. S. Murray, and C. A. Kennedy. 2003a. Responses of Amphibians to Restoration of a Southern Appalachian Wetland: Perturbations Confound PostRestoration Assessment. Wetlands 23(2):278-290. 
Petranka, J. W., C. A. Kennedy, S. S. Murray. 2003b. Response of Amphibians to Restoration of a Southern Appalachian Wetland: A Long-Term Analysis of Community Dynamics. Wetlands 23(4):1030-1042.

Pierce, B. A. 1985. Acid Tolerance in Amphibians. Bioscience 35(4):239-243.

Pulliam, H. R. 1988. Sources, Sinks, and Population Regulation. The American Naturalist 132(5):652-661.

Sarker, S. 1996. Ecological Theory and Anuran Declines. Bioscience 46(3):199-207.

Sax, D. F. and S. D. Gaines. 2003. Species Diversity: From Global Decreases to Local Increases. Trends in Ecology and Evolution 18(11):561-566.

Semlitsch, R. D. 1988. Allopatric Distribution of Two Salamanders: Effects of Fish Predation and Competitive Interactions. Copeia 1988(2):290-298.

Semlitsch, R. D. 2000. Principles for Management of Aquatic-Breeding Amphibians. Journal of Wildlife Management 64(3):615-631.

Semlitsch, R. D. 2002. Critical Elements for Biologically Based Recovery Plans of Aquatic Breeding Amphibians. Conservation Biology 16(3):619-629.

Semlitsch, R. D. and J. R. Bodie. 1998. Are Small, Isolated Wetlands Expendable? Conservation Biology 12(5):1129-1133.

Shaffer, H. B., R. A. Alford, B. D. Woodward, S. J. Richards, R. G. Altig, and C. Gascon. 1994. Quantitative Sampling of Amphibian Larvae. Pp. 130-141. In W. R. Heyer, M. A. Donnelly, R. W. McDiarmid, L. C. Hayek, and M. S. Foster (eds.), Measuring and Monitoring Biological Diversity: Standard Methods for Amphibians. Smithsonian Institution Press, Washington, D.C.

Shea, M. 2000. Channel Restoration and Riparian Reforestation Along Wilson Creek: A Demonstration Site. Unpublished Project Workplan for Bernheim Arboretum and Research Forest, 24pp.

Skelly, D. K., E. E. Werner, and S. A. Cortwright. 1999. Long-term Distributional Dynamics of a Michigan Amphibian Assemblage. Ecology 80(7):2326-2337.

Smith, D. C. 1983. Factors Controlling Tadpole Populations of the Chorus Frog (Pseudacris triseriata) on Isle Royale, Michigan. Ecology 64(3):501-510.

Snodgrass, J. W., A. L. Bryan Jr., and J. Burger. 2000a. Development of Expectations of Larval Amphibian Assemblage Structure in Southeastern Depression Wetlands. Ecological Applications 10(4):1219-1229. 
Snodgrass, J. W., M. J. Komoroski, A. L. Bryan Jr., J. Burger. 2000b. Relationships among Isolated Wetland Size, Hydroperiod, and Amphibian Species Richness: Implications for Wetland Regulations. Conservation Biology 12(2):414-419.

Travis, J., W. H. Keen, and J. Juilianna. 1985. The Effects of Multiple Factors on Viability Selection in Hyla gratiosa tadpoles. Evolution 39(5):1087-1099.

ter Braak, C. J. F., and P. Šmilauer. 1998. CANOCO reference manual and user's guide to Canoco for windows: software for canonical community ordination (version 4). Microcomputer Power, Ithaca.

U.S. EPA (United States Environmental Protection Agency). Accessed 11 November 2006. http://www.epa.gov/owow/wetlands/regs/sec404.html.

University of Kentucky Agricultural Weather Center. 2006. http://wwwagwx.ca.uky.edu/ climdata.html.

Vallan, D. 2000. Influence of Forest Fragmentation on Amphibian Diversity in the Nature Reserve of Ambohitantely, Highland Madagascar. Biological Conservation 96:31-43.

Vasconcelos, D. and A. J. K. Calhoun. 2004. Movement Patterns of Adult and Juvenile Rana sylvatica (LeConte) and Ambystoma maculatum (Shaw) in Three Restored Seasonal Pools in Maine. Journal of Herpetology 38(4):551-561.

Wassersug, R. J. and D. G. Sperry. 1977. The Relationship of Locomotion to Differential Predation on Pseudacris triseriata (Anura: Hylidae). Ecology 58:830-839.

Wilber, H. M. 1987. Regulation of Structure in Complex Systems: Experimental Temporary Pond Communities. Ecology 68(5):1437-1452.

Wilber, H. M. and R. A. Alford. 1985. Priority Effects in Experimental Pond Communities: Responses of Hyla to Bufo and Rana. Ecology 66(4):1106-1114.

Woodward, B. D. 1983. Predator-Prey Interactions and Breeding-Pond Use of Temporary-Pond Species in a Desert Anuran Community. Ecology 64(6):15491555. 


\section{APPENDIX 1}

Institutional Animal Care and Use Committee (IACUC) Approval for collection of live amphibian larvae 
May 23, 2006

Dr. Perri Eason

Associate Professor, Biology

Dear Dr. Eason:

The University of Louisville Institutional Animal Care and Use Committee (IACUC) has reviewed and approved your proposal to use laboratory animals in research and teaching entitled "Amphibian colonization of new ponds created from stream restoration" (IACUC \#05120). A copy of your signed protocol is enclosed.

IACUC approval to use laboratory animals is granted for a period of three (3) years subject to annual review. Although continued approval may be granted annually, a new application must be submitted at the end of the three years. During the approval period, it is the responsibility of the Project Director to notify the IACUC of any change in the protocol (e.g., animal species/number, personnel, procedures, project classification, funding source(s), study site, and/or use of hazardous materials). The protocol may not be transferred to any other project or investigator without IACUC approval and the Project Director may not use the IACUC approval number to conduct another project. Any adverse effects observed during the course of this activity must be reported to the IACUC.

All individuals involved with the use of laboratory animals in this project should be knowledgeable of the contents of the Guide for the Care and Use of Laboratory Animals (Guide), National Research Council (NRC), National Academy Press, 1996. A copy of the Guide can be obtained from the IACUC office (HSC, RRC Room 102). All individuals associated with this project must comply with IACUC training and occupational health and safety requirements. Any individuals associated with this project in the future must receive training and fulfill health and safety requirements.

Instructions regarding compliance with the NIH Office for Protection from Research Risks Regulations for Animal Use are also enclosed.

Sincerely,

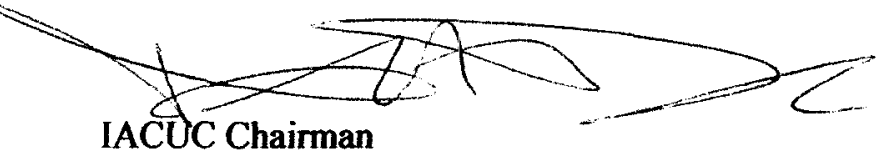

Enclosure 


\section{APPENDIX 2}

Sources for amphibian larval identification

Conant, R. and J. T. Collins. 1998. Reptiles and Amphibians: Eastern/Central North America. Peterson Field Guides. Houghton Mifflin, New York. 606 pp.

Gregoire, D. R. 2005. Tadpoles of the Southeastern United States Coastal Plain. United States Geological Survey Report. Florida Integrated Science Center. 60 pp.

Knapp, W. W. 2006. Frogs and Toads of Georgia.

http://wwknapp.home.mindspring.com/GAFrog.Toad.html.

Minton, S. A. 2001. Amphibians and Reptiles of Indiana. Indiana Academy of Science, Indianapolis, Indiana. 404 pp.

United States Geological Survey (USGS) Tadpoles and Mouthparts website. http://fisc.er.usgs.gov/c1258_Dodd/html/tadpoles.html.

United States Geological Survey (USGS) Tadpole Mouthparts website. http://cars.er.usgs.gov/armi/Guide_to_Tadpoles/mouthparts/mouthparts.html.

United States Geological Survey (USGS) Amphibian field guide websites for eggs http://www.umesc.usgs.gov/terrestrial/amphibians/field_guide/images/figure2.gif and tadpoles

http://www.umesc.usgs.gov/terrestrial/amphibians/field_guide/images/figure4.gif.

Wright, A. H. and A. A. Wright. 1995. Handbook of Frogs and Toads of the United States and Canada. Comstock Publishing Associates, Ithaca, New York. 640 pp. 


\section{CIRRICULUM VITAE}

NAME: Piper Lee Roby-Thomas

ADDRESS: Biology Department

University of Louisville

Louisville, Kentucky 40292

DOB: Louisville, Kentucky - May 7, 1977

\section{EDUCATION:}

2004-2006 M.S. -- University of Louisville; Louisville, Kentucky 40492

Thesis - Amphibian colonization of new habitat: If you build it, they will come

1995-1999 B.A. - Hanover College; Hanover, Indiana 47243

Senior Thesis - Survey of Breeding Amphibians at Jefferson Proving Ground

\section{MOST RELEVENT WORK EXPERIENCE:}

June 2005 - present. Biologist at Copperhead Environmental Consulting, Inc.,

Paint Lick, Kentucky. Supervisor: Mark W. Gumbert.

- Conduct mist-netting for bats. Capture, identify to species and process bats including removing from mist-net, taking measurements, collecting hair, guano, blood and tissue, attaching armbands, inject passive integrated transponder (PIT) tags, and affixing radio-transmitters. Perform radiotelemetry on tagged bats in order to collect roosting and foraging data. Collect data describing roost trees and characteristics of their surroundings. Take continuous bearings on bat location through the night to determine foraging areas and travel corridors for radio-tagged bats. Use Locate III to process foraging data.

- Assist in small mammal surveys using Museum Specials snap-traps, Sherman live-traps, pit-fall cups including drift fencing, and Tomahawk box traps. All specimens are identified to species and measurements taken on voucher specimens.

- Assist in herpetological and fish surveys using visual searches, auditory sampling and seine nets.

- Analyze all data using ArcView 9.0. 
Jan. 2000 - May 2003. Wildlife Biotech for the National Park Service at the Santa Monica Mountains National Recreation Area, Thousand Oaks, California. Supervisors: Dr. Seth Riley and Dr. Raymond Sauvajot

- $\quad$ Participated in a study of herpetological biodiversity. Dip-netted and visually surveyed several streams. Identified and determined relative age of amphibian species while categorizing and measuring depth, width and length of different stream segments. Took basic water chemistry measurements such as $\mathrm{pH}$, conductivity, and salinity. Constructed and monitored pit-fall trap arrays. Identified and recorded relative age of reptiles, amphibians, and small mammals captured in traps. For the herps, took body length and weight measurements and toe or scale clip for mark/recapture purposes.

- Worked chiefly on a mammalian carnivore project started in 1995. Trapped and processed bobcats, coyotes and mountain lions to collect samples (e.g., scat, blood, hair), take measurements and apply radio collars and ear tags. Tracked and located collared bobcats, coyotes and mountain lions by radio-telemetry. Used compass bearings, GPS coordinates, and a radio-tracking program called LOCATE to produce reliable, accurate positions for wildlife data and to determine home ranges and land usage. Conducted track surveys and used remotely triggered cameras under freeways to inventory and monitor mammalian carnivores.

- $\quad$ Planned, conducted, and supervised others on a small mammal survey using Sherman traps in coordination with pit-fall trap buckets to determine relative species abundance and species composition in various habitat types. Recorded species, sex, relative age, weight, total length, foot length, ear length and applied ear tags or marked with fabric pen for recapture identification.

- Oversaw volunteers and other individuals of various technical backgrounds in wildlife research projects. Interacted with the public and describing wildlife data collection activities while working in the field.

Jan. 1998 - May 1999. Field Technician for the US Fish and Wildlife Service at Jefferson Proving Ground, Madison, Indiana. Supervisor: Dr. Daryl R. Karns.

- Planned and conducted a survey of breeding amphibians, including researching scientific literature. Created a species list and determined abundance and habitat utilization for 13 species on a retired military base in southeastern Indiana. Duties included dip-netting, amphibian identification, frog and toad call surveys, preserving specimens, recording air and water temperatures, water chemistry testing, vegetation assessments, physical site descriptions, and separating breeding sites by size in order to determine the correlation between breeding success and environmental factors.

- Entered and analyzed data using Microsoft EXCEL. Compiled data in an extensive written report complete with graphs and tables using Microsoft Word and Microsoft EXCEL. Presented it orally assisted by visual display materials to college peers and professors and to an undergraduate research conference. 
June 1999 - Aug. 1999. Intern for the US Fish and Wildlife Service on Jefferson Proving Ground, Madison, Indiana. Supervisors: Dr. Joseph R. Robb and Steven Miller.

- Used radio-telemetry to locate and monitor endangered Copperbelly watersnakes at Muscatatuck National Wildlife Refuge, Seymour, In.

- Conducted field and forest songbird surveys with an emphasis on endangered Henslow's sparrows. Identified various bird species by sight, sound, and nest type. Located and monitored active nests.

- $\quad$ Conducted bat survey with an emphasis on endangered Indiana bats. Included mist-netting, bat handling, identification of various species, sexing, and taking wing measurements.

COMPUTER SKILLS:

Microsoft EXCEL 2000

Microsoft Word 2000

Microsoft PowerPoint 2000

ArcView GIS v. 3.2, 3.3, 9.0

ArcGIS v. 8.0

SAS (Statistical Analysis Software)

In-lab and field water chemistry testing

LOCATE v. I \& III (radio-tracking software)

SPSS (statistical program)

Phred (DNA analysis program)

\section{LABORATORY SKILLS:}

Gel electrophoresis

DNA sequencing

Anesthetize and preserve amphibian specimens

High Performance Liquid Chromatography (HPLC)

Gas Chromatography

\section{GRANTS/AWARDS:}

2005 - Biology Graduate Student Association (BGSA) Student Research Award 2005 - Kentucky Society of Natural History (KSNH) monetary grant 2005 - Center for Environmental Science (KIESD) monetary grant

\section{PUBLICATIONS:}

Gumbert, M. W. and P. L. Thomas. 2005. Indiana Bat Survey at the Bowes Creek Development Site - Kane County, Illinois. Technical Report submitted to Toll Brothers, Inc. Arlington Heights, IL.

Gumbert, M. W., P. L. Roby-Thomas, and K. L. McDonald. 2006. Mammals of Abraham Lincoln Birthplace and Boyhood Home National Historic Sites, Larue County, Kentucky. Technical Report, National Park Service, Hodgenville, KY.

Martin, C.O., A. A. Lee, R. A. Fischer, M. P. Guilfoyle, M. W. Gumbert, P. L. RobyThomas, K. L. McDonald, and G. A. Shirk. 2005. Threatened and Endangered Species Inventory 2004 - 2005: Plant Survey, Seasonal Bird Surveys, Mammal and Herpetological Surveys, and Aquatic Survey of Mill Creek and Otter Creek, Fort Knox, Kentucky. Technical Report, Environmental Laboratory, U.S. Army Engineer Research and Development Center, Vicksburg, MS. 
Roby, P. and M. Gumbert. 2006. Bat Survey for Fort Bragg and Camp Mackall, North Carolina. Technical Report, Fort Bragg Military Base Environmental Division, Fort Bragg, NC.

Roby-Thomas, Piper 2005. Upland Chorus Frog species account. All Wild About Kentucky's Environment (AWAKE) http://www.kentuckyawake.org.

Roby-Thomas, Piper 2005. Fowler's Toad species account. All Wild About Kentucky's Environment (AWAKE) http://www.kentuckyawake.org.

Roby-Thomas, Piper 2005. American Toad species account. All Wild About Kentucky's Environment (AWAKE) http://www.kentuckyawake.org.

\section{PRESENTATIONS:}

1999 - Survey of Breeding Amphibians at Jefferson Proving Ground. Undergraduate Research Conference, Ball State University, Muncie, Indiana.

2006 - Late Autumn Roosting Behavior of Silver-haired Bats (Lasionycteris noctivagans) at Bernheim Forest, Kentucky. Southeastern Bat Diversity Network, Chattanooga, Tennessee.

\section{AFFILIATIONS:}

Beta Beta Beta $(\beta \beta \beta)$ Biological Honors Society

Biology Graduate Student Association (BGSA)

\section{RELEVENT COURSEWORK:}

Herpetology, Aquatic Ecology, Ecology, Population and Community Ecology, Biodiversity, Conservation Biology, Animal Behavior, Plant Taxonomy, Anatomy of Vertebrates, Animal Physiology, Tropical Biology (conducted in Belize and Guatemala), Cells and Systems, Applied Statistics, Biostatistics I and II, Genetics, Evolution, Analytical Chemistry, Organic Chemistry 